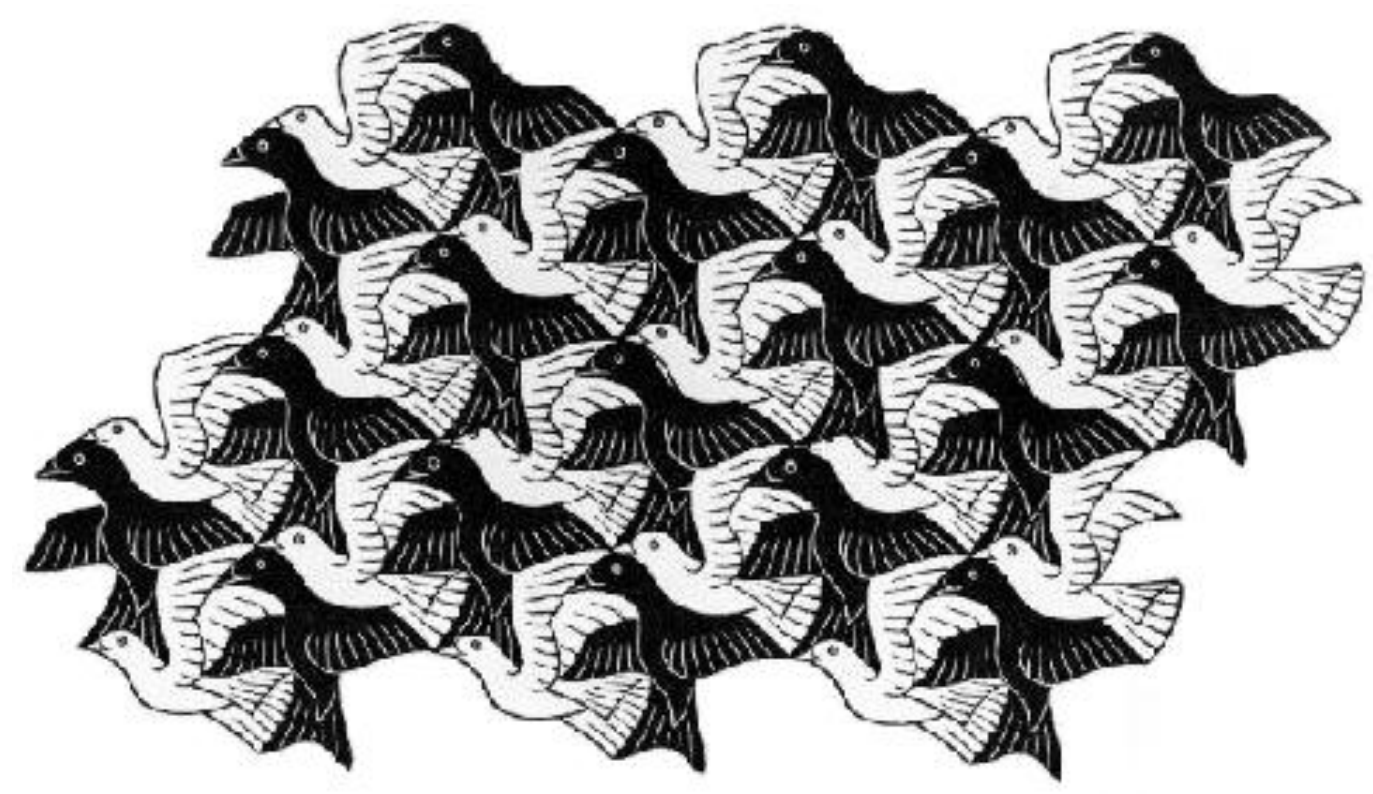

\title{
Avaliação do impacto à saúde causado pela queima prévia de palha de cana-de-açúcar no Estado de São Paulo
}

Tese apresentada à Faculdade de Medicina da Universidade de São Paulo para obtenção do titulo de Doutor em Ciências

Programa de Medicina Preventiva

Orientador: Prof. Dr. Nelson da Cruz Gouveia

Versão corrigida. Resolução CoPGr 6018/11, de 1 de novembro de 2011. A versão original está disponível na Biblioteca da FMUSP.

\section{São Paulo} 2014 
Esta dissertação ou tese está de acordo com as seguintes normas, em vigor no momento desta publicação:

Referências: adaptado de International Committee of Medical Journals Editors (Vancouver). Universidade de São Paulo. Faculdade de Medicina. Divisão de Biblioteca e Documentação. Guia de apresentação de dissertações, teses e monografias. Elaborado por Anneliese Carneiro da Cunha, Maria Julia de A. L. Freddi, Maria F. Crestana, Marinalva de Souza Aragão, Suely Campos Cardoso, Valéria Vilhena. 3a ed. São Paulo: Divisão de Biblioteca e Documentação; 2011. Abreviaturas dos títulos dos periódicos de acordo com List of Journals Indexed in Index Medicus. 
Dados Internacionais de Catalogação na Publicação (CIP)

Preparada pela Biblioteca da

Faculdade de Medicina da Universidade de São Paulo

Creprodução autorizada pelo autor

Paraiso, Maria Leticia de Souza

Avaliação do impacto à saúde causado pela queima prévia de palha de cana-deaçúcar no Estado de São Paulo / Maria Leticia de Souza Paraiso. --- São Paulo, 2013.

Tese(doutorado)--Faculdade de Medicina da Universidade de São Paulo.

Programa de Medicina Preventiva.

Orientador: Nelson da Cruz Gouveia.

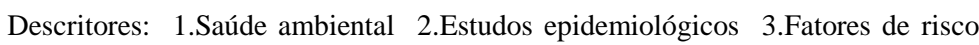
4.Impacto ambiental/análise 5.Sistemas de informação geográfica 6.Incêndios 7.Doenças respiratórias/epidemiologia 8.Doenças respiratórias/prevenção \& controle 9.Saccharum 10.Poluição do ar/efeitos adversos 11.Poluição do ar/estatística \& dados numéricos 12.Medicina preventiva 13.Material particulado 14.Indicadores de morbimortalidade 15.Brasil

USP/FM/DBD-388/13 
Aos meus pais, Alípio e Maria Stella, Pelo amor que me deram e também Por me mostrarem que uma pessoa doente Tem nome e um local de moradia e trabalho 


\section{Agradecimentos}

À minha amiga e colega Heloisa S. Bueno, que me trouxe à Faculdade de Medicina da USP, ao Laboratório de Poluição do Ar, onde concebi a ideia inicial do presente estudo.

Ao Departamento de Medicina Preventiva, com seus professores, funcionários e colegas, esse ambiente de harmonia em que me encontrei profissionalmente na área de saúde coletiva e tive o apoio material e intelectual para desenvolver esta tese.

Aos pesquisadores Bernardo Rudorrf, Daniel Aguiar, Daniela França e Fabiano Morelli, do Instituto Nacional de Pesquisas Espaciais- INPE, que disponibilizaram sem dificuldade dados sobre a colheita de cana-deaçúcar e de clima dos municípios do Estado de São Paulo.

À Miriam Regina de Souza, que elaborou a matriz de vizinhança e os mapas do estudo.

Ao Rogério Ruscitto do Prado, estatístico que orientou a análise Geoespacial.

Ao meu amigo e economista Paulo Vaz Guimarães, que me orientou quanto à inserção das variáveis sociodemográficas.

À minha amiga Ana Paula Barbosa que fez as tabelas no STATA e refez cálculos, e à Maria Inês de França Roland, pela revisão do texto.

À Dra. Beatriz Lefrève e ao Dr. Paulo Salum, neuropsicóloga e médico, que sempre acreditaram na minha recuperação de um TCE sofrido em 1988.

À minha médica e psicanalista Maria do Carmo, por me manter intelectual e emocionalmente saudável, fazendo-me seguir meu coração para uma vida plena e para o estudo das interações entre a saúde e o meio ambiente.

Ao meu orientador, Prof. Dr. Nelson da Cruz Gouveia, pela paciência com meus devaneios e muita clareza na orientação.

Ao Professor Luiz Augusto Fonseca, que me deu as orientações iniciais e sugeriu o título do trabalho. 
"a measure that brings large benefits

to the community offers little

to each participating individual."

Geoffrey Rose; Strategy of prevention: lessons from cardiovascular disease. BMJ. 1981; 282: 1850. 


\section{SUMÁRIO}

INTRODUÇÃO ................................................................ 1

$1.1 \quad$ Poluição do ar e saúde................................................... 17

1.1.1 Material particulado e doenças respiratórias................. 17

1.1.2 Ação das partículas no sistema respiratório ................. 20

1.1.3 Estudos epidemiológicos sobre poluição do ar e saúde

1.1.4 Estudos epidemiológicos sobre poluição da queima de palha de cana-de-açúcar e seus efeitos sobre a saúde

2.1 Novo ciclo da cana-de-açúcar no Brasil . 41

2.2 Colheita de cana-de-açúcar: tecnologia e mão de obra . 43

2.3 Vantagens da produção de etanol combustível a partir da cana-de-açúcar.............................................. 50

2.4 Cultura de cana-de-açúcar no Estado de São Paulo...... 53

2.4.1 Monitoramento da área plantada e do tipo de colheita de cana-de-açúcar: com queima $(\mathrm{BH})$ ou sem queima (GH)

2.4.2 Legislação de eliminação da Queima e Protocolo Agroambiental 56

2.5 Controlando outros impactos ambientais da cana-deaçúcar 
6.3.1.1 Mortalidade por doenças respiratórias 69

6.3.1.2 Morbidade hospitalar por doenças respiratórias ............ 70

6.3.2 Medidas de Exposição: variáveis independentes .......... 71

6.3.2.1 Focos de Queima .................................................. 72

6.3.2.2 Porcentagem da área de cana-de-açúcar colhida com queima prévia de palha (PQM) ................................. 73

6.3.2.3 Profundidade Óptica dos Aerossóis (Aerossol)............. 73

6.3.3 Covariáveis ................................................................... 74

6.3.3.1 Variáveis socioeconômicas ........................................... 74

6.3.3.2 Variáveis climáticas .................................................. 76

Análises ............................................................ 79

$7 \quad$ RESULTADOS........................................................... 84

7.1 Variações Climáticas, municípios paulistas com canade-açúcar em 2010 (usados no modelo). ....................... 85

7.2 Condições Socioeconômicas, municípios paulistas com cana-de-açúcar, em 2010 (usados no modelo)........

7.3 Medidas de exposição à queima da palha de cana (PQM, Focos, Aerossol), municípios paulistas (usados no modelo). Período abril a outubro de 2010.... 91

7.4 Razões de Mortalidade (RMtP) e Morbidade (RMbP) Padronizadas para doenças respiratórias, municípios paulistas (usados no modelo). Período abril a outubro de 2010 
Anexo 1 - Lei 11.241. Dispõe sobre a eliminação gradativa da queima da palha de cana-de-açúcar e dá providencias correlatas..................................................... 126

Anexo 2 - Licenciamento Ambiental ............................................... 127

Anexo 3 - Projeto CANASAT-INPE ............................................... 133

Anexo 4 - Sistema de Informações Ambientais Integrado à Saúde Ambiental (SISAM) .............................................. 134

Anexo 5 - Focos de Queima no Estado de São Paulo. 2006-2010... 135 Anexo 6 - Resolução CONAMA n 03/90 136 


\section{LISTA DE TABELAS}

Tabela 1 - Descrição das variáveis climáticas de municípios paulistas com cana usadas no modelo

Período: Abril-outubro - 2010..........................

Tabela 2 - Análise de Correlação das variáveis climáticas e RMP de municípios paulistas com cana usadas no modelo. Período: Abril-outubro - 2010.....

Tabela 3 - Descrição das variáveis socioeconômicas de municípios paulistas -2010 ......................................

Tabela 4 - $\quad$ Análise de Correlação (Pearson) entre as variáveis socioeconômicas e os desfechos nos municípios paulistas inseridos no modelo - 2010

Tabela 5 - Análise de Correlação (Pearson) entre as Medidas de exposição (PQM, Focos e Aerossol).

Tabela 6 - Análise descritiva das medidas de exposição à queima prévia, municípios paulistas - $2010 . . . . . . . . . . .$.

Tabela 7 - $\quad$ Análise de Correlação (Pearson) das medidas de exposição (PQM, Focos e Aerossol) e os desfechos

Tabela 8 - (RMtP) e (RMbP) p/ Doenças respiratórias, nos municípios paulistas - Período abril a outubro de 2010.

Tabela 9 - $\quad$ (RMtP) e (RMbP) Ajustada p/ Doenças respiratórias, nos municípios paulistas - Período abril a outubro de 2010. 


\section{LISTA DE FIGURAS}

Figura 1 - Piracicaba sem queimada de cana-de-açúcar............. 5

Figura 2 - Piracicaba com queimada de cana-de-açúcar............. 6

Figura 3 - Representação esquemática dos eventos hipotéticos após exposição às partículas ultrafinas (direita) quando comparado com a exposição a partículas finas (esquerda) ..................... 21

Figura 4 - Localização da cultura da cana-de-açúcar no Brasil. 39

Figura 5 - Corte de cana-de-açúcar enfeixada e transporte por tração animal...................................................... 43

Figura 6 - Modo de colheita, Estado de São Paulo, 2010 ........... 71

Figura 7 - Razão de Morbidade Padronizada (RMP), ajustada para internações < 5 anos. Medida de exposição Focos, SP....................................... 95

Figura 8 - Razão de Morbidade Padronizada (RMbP), ajustada para internações $<5$ anos. Medida de exposição Aerossóis, SP

Figura 9 - Razão de Morbidade Padronizada (RMbP), ajustada para internações $<5$ anos. Medida de exposição - PQM, SP............................................

Figura 10 - Mapa de Zoneamento Agroambiental para o setor sucroalcooleiro do Estado de São Paulo 


\section{LISTA DE GRÁFICOS}

Gráfico 1- Evolução (\%) do tipo de colheita de cana-deaçúcar 2006 a 2010, Estado de São Paulo

Gráfico 2 - Condições de Saneamento: proporção de domicílios com saneamento básico adequado SP, 88 2010

Gráfico 3 - Renda per capita (\%): proporção de pessoas residentes em domicílios particulares com rendimento mensal total domiciliar per capita nominal até $1 / 2$ salário mínimo SP, 2010 ...........................

Gráfico 4 - Taxa de analfabetismo da população maior ou igual a 15 anos SP,2010 


\section{LISTA DE QUADROS}

Quadro 1a - Mesorregiões Administrativas e seus municípios com RMP > 1,42 para doenças respiratórias......................................................... 99

Quadro 1b - Cont. Mesorregiões Administrativas e seus municípios com RMP > 1,42 para doenças respiratórias........................................................ 101

Quadro 1c - Cont. Mesorregiões Administrativas e seus municípios com RMP > 1,42 para doenças respiratórias 


\section{LISTA DE SIGLAS}

ACS

BIOEN-FAPESP

BM

CATT-BRAMS

CENA

CEPEA

CERESTs

CETESB

CGVAM

Cl

CID-10

Capítulo X CID 10

CNPAE

CONAB

COP 15

CONAMA

CTBE

CTC

ENSP/Fiocruz

ESALQ
American Cancer Society

Programa de Pesquisa em Bioenergia-da Fundação de Amparo à Pesquisa do Estado de São Paulo

Banco Mundial

Coupled Aerosol and Tracer Transport model to the Brazilian developments on the Regional Atmospheric Modelling System

Centro Nacional de Energia Nuclear na Agricultura - ESALQ/USP

Centro de Estudos Avançados em Economia Aplicada - ESALQ/USP

Centros de Referência em Saúde do Trabalhador

Companhia de Tecnologia de Saneamento Ambiental

Coordenação Geral de Vigilância em Saúde Ambiental

Conservação Internacional

Classificação Internacional de Doenças 10를ição;

Doenças do Aparelho Respiratório

Centro Nacional de Pesquisa em Agroenergia

Companhia Nacional de Abastecimento

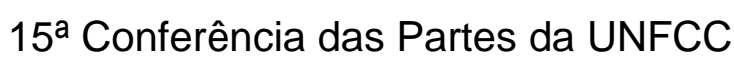

Conselho Nacional de Meio Ambiente

Laboratório Nacional de Ciência e Tecnologia do Bioetanol

Centro de Tecnologia Canavieira

Escola Nacional de Saúde

Pública/Fundação Osvaldo Cruz

Escola Superior de Agricultura Luiz de 
Queiroz

FAO

FAOSTAT

FAPESP

FERAESP

GEE

IAC

IBAMA

IBGE

IDH-M

IEA

In Metro

INPE

ISA

MCT

ONGs

Orplana

PAHs

PNAD

PNUMA

Proálcool

Projeto Canasat
Food and Agriculture Organization of The United Nations

The Statistic Division of The Food and Agriculture Organization of The United Nations

Fundação de Amparo à Pesquisa do Estado de São Paulo

Federação dos Empregados Rurais Assalariado do Estado de São Paulo

Gases do efeito estufa

Instituto Agronômico de Campinas

Instituto Brasileiro do Meio Ambiente e dos Recursos Naturais Renováveis

Instituto Brasileiro de Geografia e Estatística,

Índice de Desenvolvimento Humano Municipal

Instituto de Economia Agrícola

Instituto Nacional de Metrologia, Normalização e Qualidade Industrial.

Instituto Nacional de Pesquisas Espaciais

Instituto Socioambiental

Ministério da Ciência e Tecnologia

Organizações Não Governamentais

Organização de Plantadores de Cana da Região Centro-Sul do Brasil

Hidrocarbonetos e Hidrocarbonetos Aromáticos Policíclicos

Pesquisa Nacional por Amostra de Domicílios

Programa das Nações Unidas e Meio Ambiente

Programa Nacional do Álcool

Monitoramento da Cana-de-açúcar via imagens de satélite 
SAS

SIH

SIM

SISAM

SMA

SVS

TNC

UNFCC

Unica

USP

WWF
Secretaria de Assistência à Saúde

Sistema de Informações Hospitalares

Sistema de Informações sobre Mortalidade Sistema de Informações Ambientais Integrado à Saúde Ambiental

Secretaria do Meio Ambiente do Estado de São Paulo

Secretaria de Vigilância em Saúde

The Nature Conservancy

Convenção Quadro das Nações Unidas sobre Mudança do Clima

União da Indústria de Cana-de-açúcar

Universidade de São Paulo

World Wildlife Fund 


\section{LISTA DE SÍMBOLOS}

$\begin{array}{ll}\mathrm{CH}_{4} & \text { Metano } \\ \mathrm{SO}_{2} & \text { Dióxido de Enxofre } \\ \mathrm{CO}_{2} & \text { Dióxido de carbono } \\ \mathrm{CO} & \text { Monóxido de carbono } \\ \mathrm{N}_{2} \mathrm{O} & \text { Óxido Nitroso } \\ \mathrm{NO}_{2} & \text { Dióxido de Nitrogênio } \\ \mathbf{N O x} & \text { Óxidos de Nitrogênio } \\ \mathbf{O}_{3} & \text { Ozônio } \\ \mathbf{P M} & \text { Material Particulado } \\ \mathbf{P M}_{10} & \text { Material Particulado <10 } \mu \mathrm{m} \text { de diâmetro } \\ & \text { aerodinâmico } \\ \mathbf{P M}_{2,5} & \text { Material Particulado }<2,5 \mu \mathrm{m} \text { de diâmetro }\end{array}$




\section{LISTA DE ABREVIATURAS}

Aerossol

AlH

CAl

BH

CGD ou GBD

CPM

C-R

DCNT

DPOC

Ei

Focos

GH

MCMC

Oi

PPBV

PQM

PTS ou TPS

RMP ou SMR

RR

SIG ou GIS

TM

UR

YLD

YLL
Profundidade Óptica dos Aerossóis

Autorizações de Internação Hospitalar

Complexo Agroindustrial Canavieiro

Burnt harvest, cana colhida com queima

Carga Global da Doença

Coarse Particulate Mode

Concentração-Resposta

Doenças crônicas não transmissíveis

Doença pulmonar obstrutiva crônica

Internações esperadas

Focos de Queima

Green harvest,cana colhida sem queima

Método de Estimação de Monte Carlo

Óbitos Esperados

Partes por bilhão em volume

Porcentagem de Queima prévia de palha de cana por Município

Partículas Totais em Suspensão

Razão de Mortalidade Padronizada

Risco Relativo

Sistema de Informações Geográficas

Thematic Mapper

Umidade Relativa do ar

Years Lived with Disability

Years of Life Lost 


\section{Resumo}

Paraiso MLS. Avaliação do impacto à saúde causado pela queima prévia de palha de cana-de-açúcar no Estado de São Paulo [Doutorado]. São Paulo: Faculdade de Medicina/Universidade de São Paulo; 2013.

O etanol de cana-de-açúcar se consolida como combustível renovável, o que promove nova expansão da cultura da cana-de-açúcar no Brasil e, principalmente, no Estado de São Paulo. Como a queima prévia controlada da palha de cana-de-açúcar ainda é considerada uma prática agrícola necessária para a viabilização econômica da colheita, em mais de $70 \%$ dos municípios do Estado de São Paulo a população é obrigada a conviver com essa poluição. Para estudar a distribuição desse fator de risco e sua relação com a saúde, realizei um estudo epidemiológico ecológico nos 645 municípios de São Paulo. Usei um modelo Bayesiano de regressão multivariada relacionando os efeitos na saúde com a exposição à queima prévia da palha de cana-de-açúcar, sendo controlados os efeitos das variações socioeconômicas (saneamento, educação e renda) e climáticas (temperatura máxima, umidade mínima e precipitação), através da inserção das mesmas no modelo. O efeito sobre a saúde foi medido por meio da Razão de Mortalidade e Morbidade Padronizada (RMP) dos desfechos: óbitos por doenças respiratórias nas faixas etárias acima de 65 anos e internações por doença respiratória, nas faixas etárias menores de 5 anos e acima de 65 anos de cada um dos municípios. Usei como medida de exposição à queima prévia dados obtidos no INPE: percentual da área de cana colhida com queima (PMQ), níveis médios de Aerossol e Focos de queima, testadas separadamente. Para resolver a autocorrelação entre os dados, estes foram considerados conforme sua disposição espacial, através da construção de uma matriz de vizinhança dos 645 municípios do Estado. Utilizei o método de simulação de Monte Carlo via Cadeias de Markov (MCMC) para 'suavizar' as estimativas da RMP. A análise demonstrou que existe associação entre a queima prévia da palha de cana-de-açúcar e a ocorrência de doenças respiratórias, porque o aumento nos focos de queima (Focos) esteve associado significativamente com o aumento das internações por doenças respiratórias, na faixa etária de menores de cinco anos. Os resultados mostraram que a queima prévia da palha da cana-de-açúcar oferece efetivamente risco à saúde da população e, adicionados aos mapas coropléticos gerados, oferecem subsídios para a vigilância epidemiológica e contribuem para o estabelecimento de políticas públicas para controle da poluição do ar, que contemplem além dos grandes centros urbanos, os pequenos municípios. A eliminação desse fator de risco deve fazer parte das medidas primordiais de prevenção à saúde a serem adotadas no Estado.

Descritores: Saúde ambiental; Estudos epidemiológicos; Fatores de risco; Impacto ambiental/análise; Sistemas de informação geográfica; Incêndios; Doenças respiratórias/epidemiologia; Doenças respiratórias/prevenção \& controle; Saccharum; Poluição do ar/efeitos adversos; Poluição do ar/estatística \& dados numéricos; Medicina preventiva; Material particulado; Indicadores de morbi-mortalidade; Brasil. 


\begin{abstract}
Paraiso MLS. Evaluation of the health impact caused by the pre-harvest burning of sugarcane straw in the State of São Paulo [Doutorado]. São Paulo: "Faculdade de Medicina, Universidade de São Paulo"; 2013.

Ethanol from sugarcane is consolidated as a renewable fuel which promotes further expansion of the culture of sugarcane in Brazil and especially in the State of São Paulo. As the controlled pre-harvest burning of sugarcane straw is still considered an agricultural practice necessary for the economic viability of this crop in more than $70 \%$ of municipalities in the State of São Paulo the population is forced to live with this pollution. To study the distribution of this risk factor and its relationship with the health of the population, I conducted an ecological study in the 645 municipalities of São Paulo. I used a Bayesian multivariate regression model relating the health effects and the exposure to previous straw burning of sugarcane, controlling the effects of socioeconomic factors (sanitation, education and income) and climate (maximum temperature, minimum humidity and precipitation) by the insertion of these variables in the model. The effect on health was measured by Standardized Mortality and Morbidity Ratio (SMR) of the outcomes: deaths from respiratory diseases in the age group above 65 years old and admissions for respiratory disease in children less than 5 years old and above 65 years old of each of the municipalities. I used as a measure of exposure to the pre-harvest burning data obtained at INPE: percent of sugarcane area harvest with burning (PMQ), levels of Aerosol and Spotlights of burning, tested separately. To solve the autocorrelation in the data these were considered as their spatial arrangement, by building a neighborhood matrix of the 645 municipalities in the state. I used the Markov Chain-Monte Carlo simulation method (MCMC) to 'soften' the estimates of the SMR. The analysis showed that there is an association between previous straw burning of sugarcane and respiratory diseases, because the increase in outbreaks of burning (Spotlights) was significantly associated with increased hospital admissions for respiratory diseases in children aged under five years old. The results show that the previous straw burning of sugarcane effectively offers health risk to the population and added to the choropleth maps generated provide valuable information for epidemiological surveillance and contribute to the establishment of public policies for the control of air pollution, which should contemplate beyond the major urban centers, the small towns. The elimination of this risk factor should be part of a primordial prevention measure to be taken in the state.
\end{abstract}

Descriptors: Environmental health; Epidemiologic studies; Risk factors; Environmental impact/analysis; Geographic information systems; Fires; Respiratory tract diseases/prevention \& control; Respiratory tract diseases/epidemiology; Saccharum; Air pollution/adverse effects; Air pollution/statistics \& numerical data; Preventive medicine; Particulate matter; Indicators of morbidity and mortality; Brazil. 
INTRODUÇÃO 


\section{INTRODUÇÃO}

As doenças respiratórias constituem importante causa de morbidade e mortalidade global, sendo a poluição do ar um de seus mais importantes fatores de risco. Análise sistemática realizada por Lim et al. (2012), traz a poluição do ar, na forma de material particulado fino $\mathrm{PM}_{2,5}$ (material particulado $<2,5 \mu \mathrm{m}$ diâmetro aerodinâmico), como um dos dez maiores fatores de risco, responsáveis pela atual Carga Global de Doença (CGD). A poluição do ar contribuiu com 3,1 milhões de anos de vida perdidos devido à mortes prematuras $(\mathrm{YLL})^{1}$ e 76 milhões de anos de vida vividos com incapacidade, $(\mathrm{YLD})^{2}$. Estudos anteriores da Carga Global da Doença relatam menores valores de risco relacionados à poluição do ar (Murray e Lopez, 2013). Segundo o Health Effects Institute, a poluição do ar apresentou um aumento de sua importância por dois motivos principais. Primeiramente, devido às novas técnicas que capturam estimativas globais de poluição por Material Particulado, baseadas em medidas no nível do solo e/ou sensoriamento remoto. Segundo, análises mais recentes sobre os efeitos dos níveis de poluição do ar sobre a morbidade e a mortalidade vêm mostrando que a magnitude desses efeitos são maiores do que observado anteriormente (HEI, Winter 20122013).

\footnotetext{
${ }^{1}$ Years of Life Lost, traduzido como anos de vida perdidos.

${ }^{2}$ Years lived with Disability traduzido como anos vividos com incapacidade.
} 
Assim, justifica-se a necessidade de redução ou eliminação de importantes e persistentes fatores de risco para a ocorrência de doenças respiratórias, como a poluição do ar devido às queimadas em geral; tanto as realizadas nas cidades, para limpeza de terrenos, quanto as realizadas na agricultura, na abertura de pastos, preparação do solo e, principalmente, na queima prévia de palha da cana-de-açúcar (Saccharum L.).

No caso da cana-de-açúcar, as queimadas são uma prática anual e o período de queima coincide com o de clima seco e frio (Manço, 1992), aumentando o risco para a incidência de doenças respiratórias. A coincidência entre a safra da cana-de-açúcar e o período de clima seco tem sido utilizada como argumento pelos interessados na manutenção das queimadas. Contesta-se, desse modo, associação entre a queima prévia da palha da cana-de-açúcar e os danos à saúde já verificados em trabalhos científicos (Cançado, 2003; Arbex et al., 2000; Lopes, 2006; Lopes et al., 2006; Lopes et al., 2007). É verdade que o fogo sempre esteve presente na cultura da cana, mas somente no processo da fabricação de açúcar e álcool. Fogo Morto, obra de José Lins do Rego (2013) publicada originalmente em 1943, faz justamente alusão ao encerramento das atividades produtivas de um engenho no Nordeste brasileiro. No entanto, é necessário recuperar a história e reconhecer que a queima prévia da palha, como é feita atualmente, não existiu desde a introdução da cultura da cana-de-açúcar no Brasil. A queima da palha somente foi adotada como prática regular no final dos anos 1950, para facilitar o corte da cana-de-açúcar, após a introdução das máquinas 
carregadoras. Segundo Szmercsáni (1994), a queima prévia da palha de cana-de-açúcar foi introduzida por motivo econômico, ou seja, para aumentar a produtividade da colheita manual. $\mathrm{O}$ aumento da escala de produção das usinas gerou a necessidade de aumento do fornecimento diário de cana-de-açúcar cortada para abastecimento das fornalhas. Para que não houvesse pressão sobre a demanda por mão de obra, foi introduzida a queima prévia da palha. Os custos de produção não aumentaram, pois o corte era mais fácil sem a palha, além de prevenir acidentes de trabalho relacionados à presença de animais peçonhentos nos canaviais.

Atualmente, com o desenvolvimento de novas variedades de canade-açúcar, o período de queimadas no centro-sul do país foi ampliado. Ele tem início em março ou abril e se estende até novembro ou dezembro, segundo dados do Projeto Canasat do Instituto Nacional de Pesquisas Espaciais (INPE) ${ }^{3}$. Considerada uma prática agrícola bem sucedida, a queima prévia da palha se tornou parte do modelo de produção de canade-açúcar no Brasil. Existe interesse na sua expansão para outras nações na estratégia de ampliação da produção de biocombustíveis (Neves e Chaddad, 2012).

É interessante saber que a queima prévia da palha não é prática usual em todos os países que cultivam cana-de-açúcar, como Cuba e Austrália (Ripoli e Ripoli, 2009), ressaltando ainda que, predominante no Brasil, esse não constitui o único modo de produção.

\footnotetext{
${ }^{3}$ Disponível em: www.dsr.inpe.br/canasat.
} 
No presente estudo, tomo como ponto de partida a queima prévia de palha de cana-de-açúcar no Estado de São Paulo, utilizando como exemplo o municípío de Piracicaba (Figuras 1 e 2). A queima da palha da cana-de-açúcar lança partículas e gases a grande distância, e as massas de ar levam a fuligem para casas, ruas e logradouros públicos. Essa poeira (carvãozinho) sedimentada com a umidade do sereno, transformase em um lodo negro que se deposita nos quintais das casas. Além do transtorno evidente aos habitantes desse município e de outros vizinhos, devido ao aumento dos serviços de limpeza pública e lavanderia, há evidências científicas de que as queimadas provocam acidificação das águas pluviais (Lara et al., 2001) das bacias hidrográficas a que pertencem os rios de cidades canavieiras, dentre outros problemas.

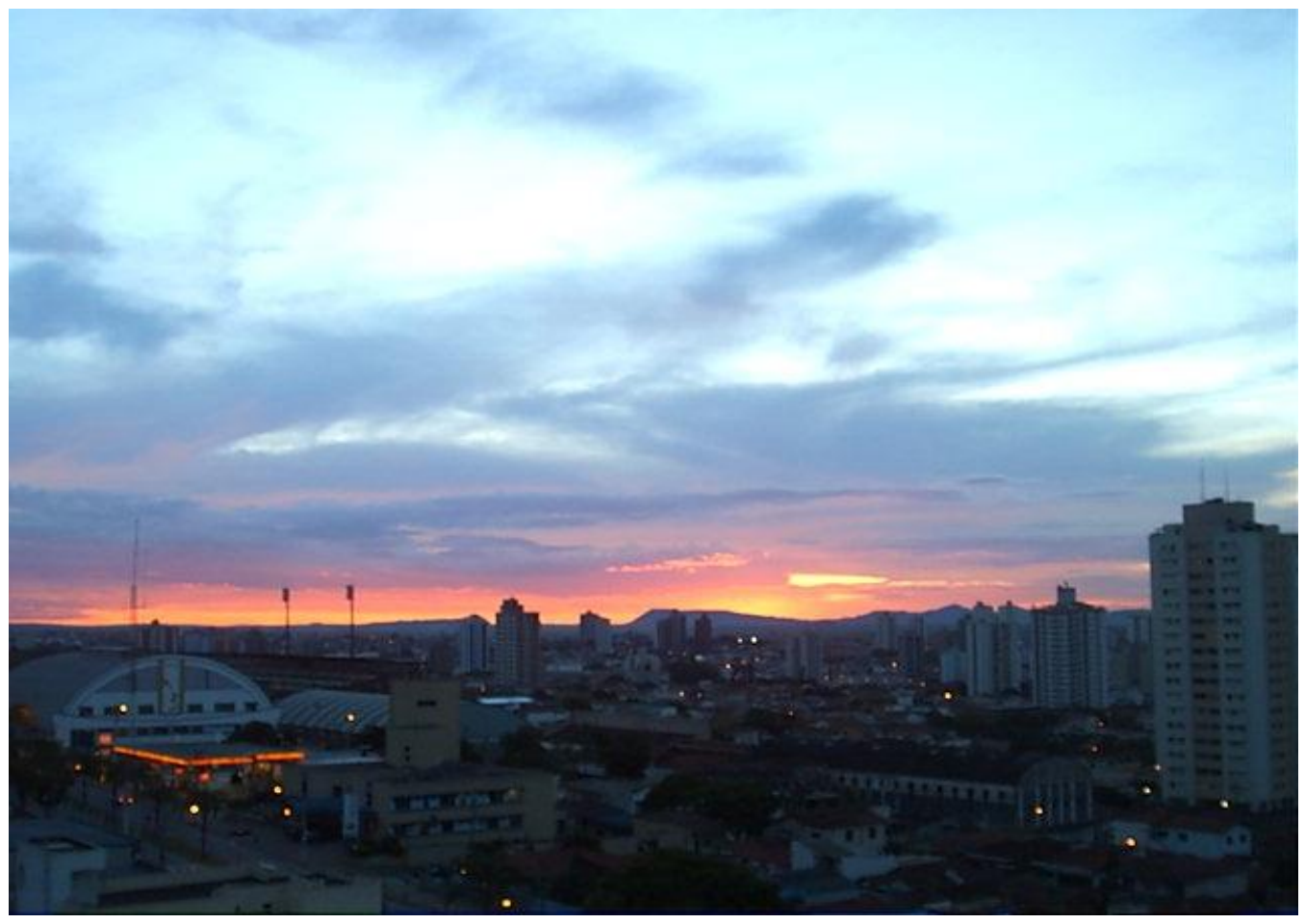

Figura 1. Piracicaba sem queimada de cana-de-açúcar 


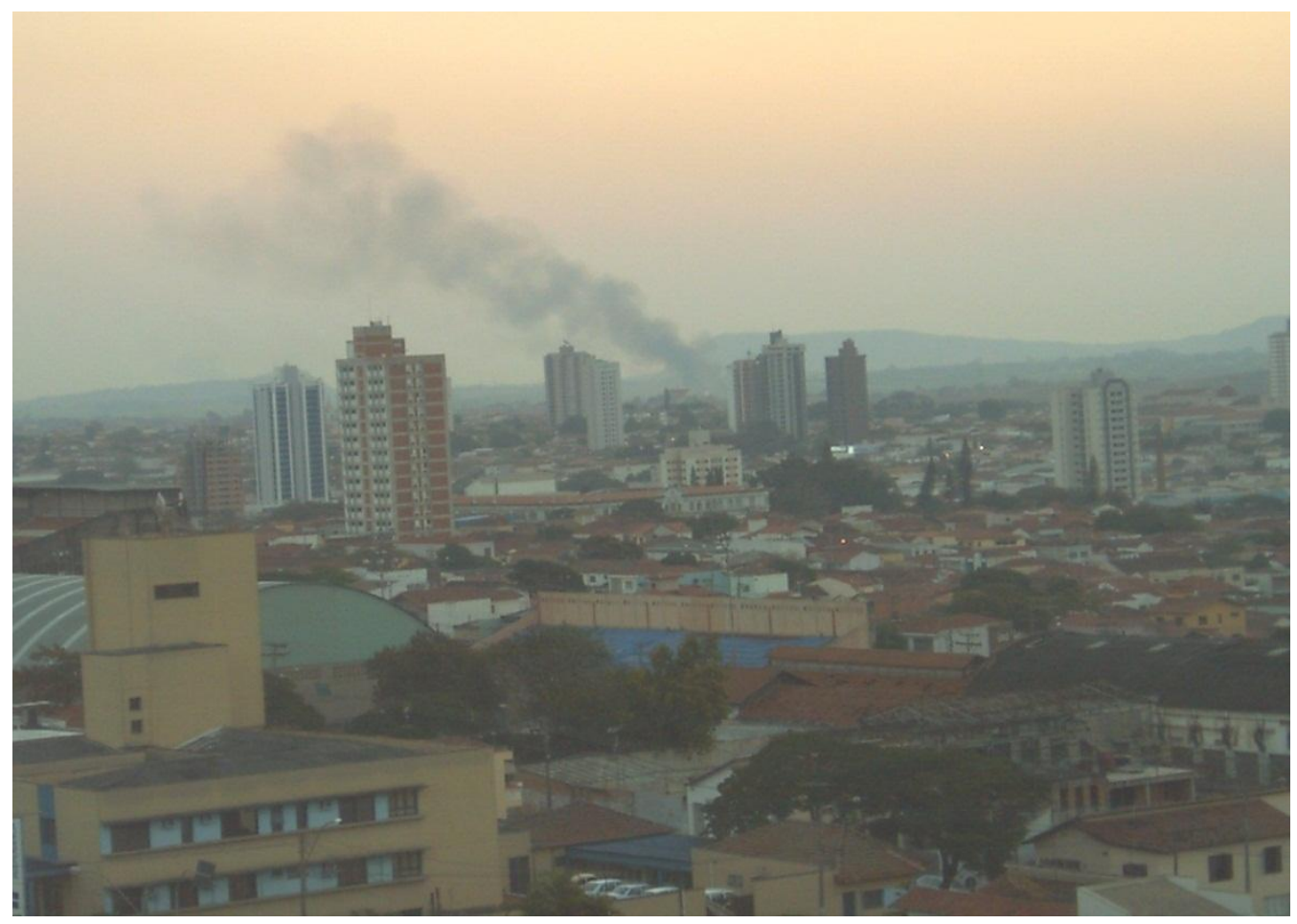

Figura 2. Piracicaba com queimada de cana-de-açúcar

A combustão incompleta gerada pela queima prévia emite partículas finas $\left(\mathrm{PM}_{2,5}\right)$ e grossas $\left(\mathrm{PM}_{10}\right)$ também chamadas de inaláveis ${ }^{4}$ : monóxido (CO) e dióxido de carbono $\left(\mathrm{CO}_{2}\right)$, aldeídos (acroleína, formaldeído), metano $\left(\mathrm{CH}_{4}\right)$, óxidos de nitrogênio (NOx) e óxido nitroso $\left(\mathrm{N}_{2} \mathrm{O}\right)$, hidrocarbonetos e hidrocarbonetos aromáticos policíclicos (PAHs) e aerossóis (Arbex et al., 2004). Em contato com o sol, muitos desses gases - como o monóxido de carbono, o metano e os hidrocarbonetos - podem produzir ozônio $\left(\mathrm{O}_{3}\right)$, por meio de reação fotoquímica (Ribeiro e Assunção, 2002). As folhas do canavial queimam muito rápido. Em dez minutos, uma massa seca de aproximadamente 20 toneladas/hectare se transforma em fuligem e avança para as cidades do entorno, conforme a direção dos ventos (Rocha et al.,

${ }^{4}$ Partículas de material sólido ou líquido suspenso no ar, na forma de poeira, neblina, aerossol, fumaça, fuligem etc., que podem permanecer no ar e percorrer longas distâncias. Faixa de tamanho $<10 \mu$. 
2005). A proporção de palhiço ${ }^{5}$ no canavial depende da variedade de canade-açúcar e está associada a aspectos da idade (em meses) da plantação e ao número da soqueira ${ }^{6}$ (rebrotas de $1^{\circ}$ ao $5^{\circ}$ corte) (Ometto et al., 2005).

No período da queima, há maior prevalência de internações hospitalares e visitas às emergências médicas por problemas respiratórios, destacando-se a asma, a pneumonia e a bronquite (Ribeiro e Assunção, 2002). Estudos têm demonstrado essa associação, mas as evidencias não são suficientes para afirmar que os referidos poluentes sejam os únicos responsáveis por tais problemas, tendo em vista que outros fatores, como clima frio e baixa umidade relativa do ar também contribuem para essa situação (Roseiro et al., 2006).

Apesar das citadas consequências à saúde, são poucos os estudos a respeito do volume de poluentes emitidos pela queima da palha de cana-deaçúcar (Lopes et al., 2007), o que dificulta uma avaliação mais precisa dos efeitos nocivos provocados por essa prática agrícola.

De acordo com comunicação oficial da Companhia de Tecnologia de Saneamento Ambiental ${ }^{7}$ (CETESB)/Piracicaba no documento Alguns aspectos relativos à queima dos canaviais (Companhia de Tecnologia de Saneamento Ambiental, 1981 apud Ripoli e Ripoli, 2009), já em 1981, a quantidade de material particulado (carvãozinho) emitido na atmosfera pela queima de cana foi verificado como da ordem de $4 \mathrm{kgf} / \mathrm{t}$ (kilogramaforça/tonelada) de colmo de cana. Isso significa que, para uma

\footnotetext{
${ }^{5}$ Palha de cana-de-açúcar.

${ }^{6}$ Rebrotação da planta de cana.

${ }^{7}$ Atualmente, denominada Companhia Ambiental do Estado de São Paulo.
} 
produtividade de 100 toneladas de cana-de-açúcar por hectare (ha), são emitidos 400kgf de material particulado por hectare de área de queima.

A preocupação com o aumento da poluição gerada pela queima prévia da palha de cana-de-açúcar, em especial devido ao aumento da produção estimulado pelo Programa Nacional do Álcool (Próalcool) nos anos 1970, levou ao desenvolvimento do Projeto Fogo (Marinho e Kirchoff, 1991) para estudo do efeito das queimadas sobre os gases atmosféricos ozônio $\left(\mathrm{O}_{3}\right)$, monóxido de carbono $(\mathrm{CO})$ e dióxiodo de carbono $\left(\mathrm{CO}_{2}\right)$. Foi observado que, durante o período de queima da palha da cana-de-açúcar, havia concentração de até 80 partes por bilhão em volume (PPBV) para $\mathrm{O}_{3}$, e de 600 PPBV para CO. Na época, considerava-se que a absorção de $\mathrm{CO}_{2}$ pela cana-de-açúcar durante a fotossíntese - necessária ao crescimento da planta na safra seguinte - absorveria todo $\mathrm{o} \mathrm{CO}_{2}$ emitido na queima da palha (Gonçalves, 2005). Portanto, mesmo com a constatação dessa alta emissão de ozônio $\left(\mathrm{O}_{3}\right)$ e monóxido de carbono $(\mathrm{CO})$ acima dos padrões estabelecidos pelo Conselho Nacional do Meio Ambiente (CONAMA) ${ }^{8}$, o etanol foi considerado um combustível limpo (Marinho e Kirchoff, 1991).

Atualmente, o INPE (França et al., 2012) desenvolve trabalhos para determinar com precisão o fator de emissão $\left(\mathrm{FE}^{9}\right)$, de poluentes da queima da palha de cana-de-açúcar. Além disso, uma nova metodologia está sendo proposta a fim de reduzir as incertezas na estimativa de áreas queimadas com base nos focos de calor obtidos por sensoriamento remoto, particularmente no que se refere à omissão de informações sobre a queima

\footnotetext{
${ }^{8}$ Padrão CONAMA, Resolução 003/90, padrão $\mathrm{O}_{3}=160 \mu \mathrm{g} / \mathrm{m}^{3} ; \mathrm{CO}=150 \mathrm{ppm}$.

${ }^{9} \mathrm{FE}$ representa a quantidade de material produzido por determinada quantidade de
} material combustível seco consumido. 
da palha da cana-de-açúcar, sua extensão e/ou duração. Nessa nova abordagem, o modelo de emissões 3BEM (Brazilian Biomass Burning Emission Model) (Longo et al., 2010) fez o cálculo das emissões com base na área com cana-de-açúcar queimada em um determinado período, ao invés de calculá-las apenas baseado na área queimada estimada por meio dos focos de calor detectados por satélite. Os resultados dessa nova metodologia poderão ser utéis para determinar com maior precisão o efeito da queima da palha de cana-de-açúcar nos futuros estudos sobre impacto da queima à saúde.

Qual é o impacto da queima prévia da cana-de-açúcar sobre a saúde da população do Estado de São Paulo, sendo ele o maior produtor dessa matéria-prima e responsável por mais $60 \%$ da produção dela no país?

Neste estudo, o mais importante é demonstrar que existe associação entre a queima prévia e os impactos na saúde em grande parte do Estado, independentemente das condições climáticas e socioeconômicas, e não obter o valor exato do impacto da queima prévia na saúde. Dessa forma, busco contribuir para a adoção de medidas preventivas em relação à danos à saúde relacionados à queima prévia da palha de cana-de-açúcar.

Embora médicos e ambientalistas alertem para os riscos envolvidos no uso da queima prévia sobre a saúde das populações, empresários e produtores rurais defendem o uso desse modelo, tendo como argumento a necessidade de manutenção do emprego de centenas de trabalhadores rurais. Desse modo, a queima da palha da cana-de- 
açúcar e os transtornos por ela causados acabaram sendo incorporados à vida das cidades onde a produção de cana-de-açúcar se destaca como atividade econômica. Seus defensores alegam que se deve 'suportar' os incômodos do progresso econômico e da vida moderna. Parece anacrônico, mas esse foi o argumento utilizado no clássico livro Primavera Silenciosa, escrito há cinquenta anos (Carson, 2010), quando fazia referência ao uso de agrotóxicos contaminantes químicos. É uma situação análoga aos incômodos sofridos atualmente pelas populações dessas cidades em relação à queima prévia da palha de cana-de-açúcar. Justifica-se a prática pelos benefícios econômicos de curto prazo que a cultura da cana-de-açúcar traria para a sociedade.

Estudos de prevenção de doenças crônicas não transmissíveis, DCNT, em indivíduos e populações mostram que existe grande potencial para prevenção de doenças em larga escala, em países e comunidades (Ezzati e Riboli, 2012). Desse modo, a eliminação da queima prévia da palha da cana-de-açúcar poderia ser uma política pública a ser incorporada na agenda da saúde do Estado e, ao contrário das medidas de prevenção para uma doença específica, poderia agir para prevenção de várias doenças. As políticas e ações adotadas para esse fim necessitam, além do suporte político, de instituições capazes de criá-las, dotando-se com instrumentos para monitoramento e, quando necessário, redirecionamento de ações. Corroborando essa ideia, na Declaração da Reunião de Alta Cúpula das Nações Unidas em 2011 foi determinada a priorização da prevenção às DCNT (Beaglehole, 2011) e, enfatizada a necessidade de abordagens e ações multissetoriais. Com este trabalho, 
espero contribuir para uma mudança de postura da sociedade em relação à queima prévia no sentido de promover o melhoramento das condições de saúde da população do Estado de São Paulo.

Como mencionado anteriormente, a queima prévia da palha da cana-de-açúcar e os danos dela provenientes tornaram-se tão presentes que passaram a ser considerados apenas mais um componente da paisagem das cidades canavieiras paulistas. Essa é a realidade atual, apesar de o Código Florestal de 1965 ter estabelecido, no Artigo nํ2, que é proibido o uso de fogo nas florestas e demais formas de vegetação.

Devido à importância da cultura da cana-de-açúcar no Estado de São Paulo, seu uso foi regulamentado por meio de legislação específica. Em 1984, foi firmado o 'Acordo de Guariba', para proporcionar melhores condições aos trabalhadores da cana-de-açúcar. Isso encareceu, do ponto de vista do produtor, o custo da produção, o que levou à introdução de máquinas de colheita do 'tipo australiano' no processo produtivo (Scopinho e Valarelli, 1995). O uso dessas máquinas não dispensa a prévia queima da palha, mas reduz o custo da mão de obra. Em 2010, $10 \%$ da colheita de cana-de-açúcar ainda eram feitos com esse tipo de máquina (Rudorff et al., 2010).

No início dos anos 1980, o aumento da preocupação com as queimadas no Estado de São Paulo (Gonçalves, 2005) levou a CETESB a promover dois Simpósios (1984 e 1985) sobre o tema Queima de palha dos canaviais (São Paulo, CETESB, 1997). Segundo Scopinho et al.(1999), a partir de 1990, o Poder Judiciário instaurou uma verdadeira guerra contra as usinas da região canavieira paulista, em razão da prática 
das queimadas, passando a responsabilizar judicialmente os responsáveis (Gonçalves, 2005). No entanto, a questão somente adquiriu vulto depois da Conferência do Rio, a Eco-92, quando se verificou o fortalecimento dos movimentos sociais e ambientalistas. A sociedade civil, mobilizada em associações ambientalistas e de promotores públicos, reivindicou o fim das queimadas, em virtude dos efeitos deletérios à saúde do trabalhador e da população em geral. Em 1997, a pressão da sociedade civil pelo abandono da queima prévia obrigou a celebração do Acordo dos Bandeirantes, transformado posteriormente no Decreto no 42.056 (São Paulo, 1997) que estabelecia o ano de 2006 como limite para o fim da queima prévia da cana-de-açúcar no estado. O Decreto se transformou na Lei Estadual no 11.241 (Gonçalves, 2005), que ampliou o prazo para o fim das queimadas para 2021 nas áreas mecanizáveis (declividade do terreno menor que 12\%), e para 2031 naquelas em que a lei considera não haver tecnologia para a mecanização (declividade do terreno maior que 12\%) (Anexo 1). A lei prevê um processo de redução gradativa da área queimada, mediante a liberação de autorizações de queima. Essa legislação vigente poderia ser interpretada como um retrocesso, uma vez que o Decreto de 1997 previa o fim das queimadas para o ano de 2006.

Medidas foram tomadas para mitigar os efeitos ou mesmo determinar o fim da queima prévia da palha de cana-de-açúcar, mas sempre prevaleceram as dificuldades de monitoramento e argumentos relativos à previsão de problema social causado pelo desemprego da mão de obra da cana-de-açúcar. 
A partir de 2003, por demanda da União da Indústria de Cana-deaçúcar (Unica), foi desenvolvido pelo INPE o projeto Canasat, que faz uso de sensoriamento remoto e, assim, fornece condições efetivas de monitoramento do cultivo da cana-de-açúcar no estado. Ele foi desenvolvido em colaboração com o Centro de Estudos Avançados em Economia Aplicada (Cepea) da Escola Superior de Agricultura Luiz de Queiroz (ESALQ/USP) e o Centro de Tecnologia Canavieira (CTC).

No Estado de São Paulo, o Projeto Canasat monitora desde 2006, além da produção, o tipo de colheita de cana, com ou sem queima prévia A partir de 2005, ele foi expandido para os Estados de Goiás, Minas Gerais, Mato Grosso, Mato Grosso do Sul e Paraná. Em 2010, passou a cobrir também os Estados do Espírito Santo e do Rio de Janeiro, mapeando as áreas cultivadas por cana-de-açúcar em toda a região Sudoeste do Brasil.

O bom momento econômico do setor sucroenergético, permitiu que, em 2007, houvesse um entendimento entre o Governo do Estado de São Paulo, as usinas e fornecedores de cana-de-açúcar para a eliminação gradual da queima prévia (São Paulo, SMA, 2007). Foi firmado o Protocolo Agroambiental, um acordo assinado pelo Governador e seus Secretários de Estado de Meio Ambiente e de Agricultura; pelos presidentes da Unica e da Organização de Plantadores de Cana da Região Centro-Sul do Brasil (Orplana) (Unica, 2007). Por esse acordo, os atores envolvidos se comprometeram voluntariamente a antecipar o prazo legal do fim da queima prévia da cana-de-açúcar para o ano de 2014 na área mecanizável (declividade<12\%), e para o ano de 2017, nas áreas 
ainda hoje não mecanizáveis (declividade>12\%), considerando o atual nível de tecnologia. Nas mesmas bases, seguiram-se acordos em outros estados: Minas Gerais (Minas Gerais, 2008) e Espírito Santo (Espírito Santo, 2009).

A efetividade da eliminação gradual da queima prévia com a aplicação do Protocolo é continuamente verificada pelo Canasat. $\mathrm{Na}$ publicação de Aguiar et al. (2011), verifica-se a situação da cultura de cana-de-açúcar, do plantio à colheita, e a distribuição do percentual de cana-de-açúcar colhida com queima $(B H)^{10}$ e sem queima $(\mathrm{GH})^{11}$ no estado, no período de 2006 a 2011. Nesse período, a expansão da cultura no Estado de São Paulo foi de 1,5 milhão de hectares. Como a limitação da queima estabelecida pelo Protocolo é determinada apenas em um percentual da área total plantada, verifica-se a diminuição apenas relativa da área de colheita com queima $(\mathrm{BH})$, pois, em valores absolutos, não houve praticamente redução na área de colheita com queima $(\mathrm{BH})$. A área sem queima foi compensada pelo aumento de área total da cultura de cana-de-açúcar (Aguiar et al., 2011).

Os trabalhos sobre o mapeamento da colheita de cana-de-açúcar (Rudorff, 2010; Aguiar et al., 2011; Aguiar et al., 2007), embora realizados por uma mesma equipe de pesquisadores, mostram resultados diferentes. O trabalho mais recente demonstra que, se continuado o ritmo atual de avanço da eliminação da queima no estado, o prazo para sua conclusão deverá ser postergado para 2015 ou 2016. Pelo Gráfico 1, observo que,

\footnotetext{
${ }^{10}$ Burnt harvest.

${ }^{11}$ Green Harvest.
} 
de 2006 a 2010, houve incremento de mais de $100 \%$ na área de colheita de cana-de-açúcar sem queima.

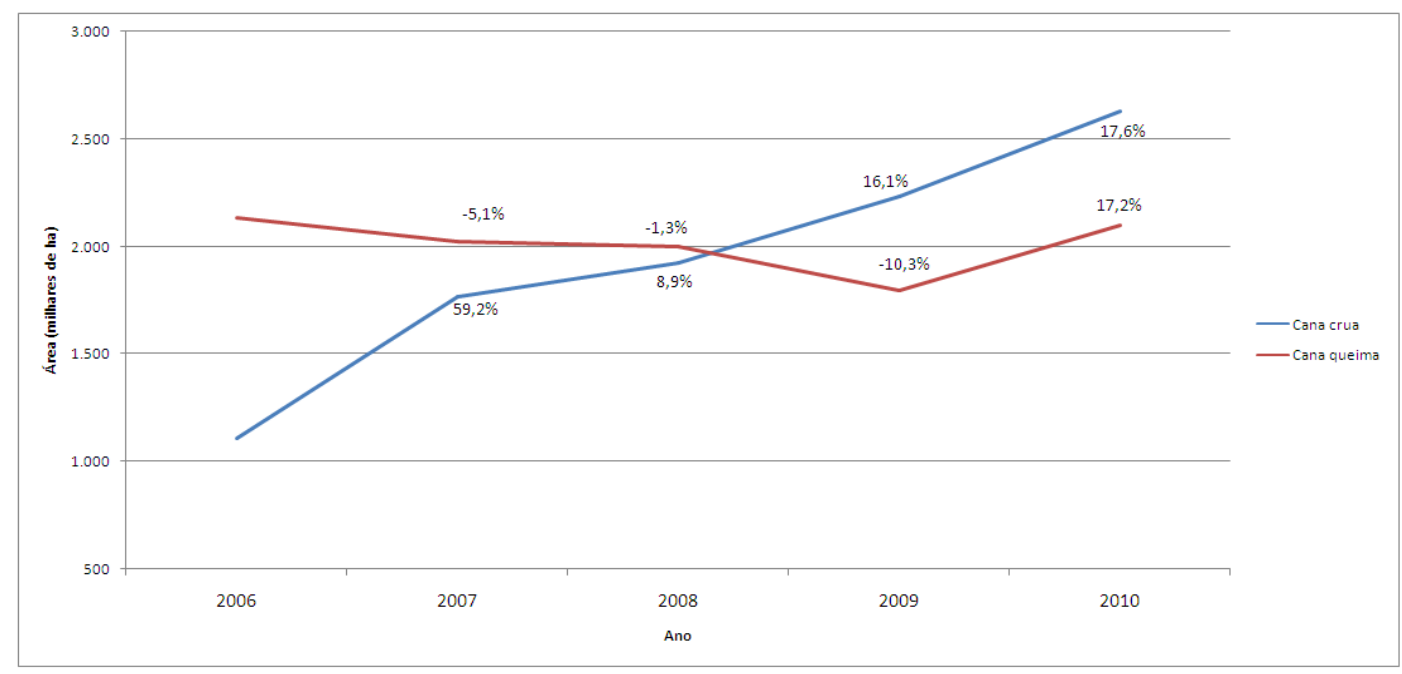

Fonte: Projeto Cana Sat.

Observação: Os valores percentuais representam as variações entre dois momentos no tempo.

Gráfico 1. Evolução (\%) do tipo de colheita de cana-de-açúcar, Estado de São Paulo 2006 a 2010

No mesmo período, a redução de área com queima $(\mathrm{BH})$ foi de apenas $0,5 \%$. No ano de 2010 , houve um período seco muito grande, tendo como consequência novo impulso da área de colheita de cana-deaçúcar com queima. Esta cresceu aproximadamente (17\%) na mesma proporção do que cresceu a área de plantio (Aguiar et al., 2011).

No restante do país, a prática da queima prévia foi expandida sem regulamentação. Somente em 1998, com o Decreto Federal oㅜ 2.661, essa questão foi regulamentada e foram estabelecidas normas de precaução relativas ao emprego do fogo em práticas agropastoris e florestais. O Capítulo IV, Artigo n¹6 do referido Decreto, regulamenta o emprego do fogo como método despalhador e facilitador do corte da 
cultura canavieira em áreas passíveis de mecanização da colheita, e preconiza sua gradual eliminação.

Em 1999, por meio da Portaria ํㅜ 345, o Instituto Brasileiro do Meio Ambiente e dos Recursos Naturais Renováveis (IBAMA) tornou-se responsável pela autorização para queima no nível federal. Essa autorização deve ser obtida pelo interessado junto ao IBAMA ou em órgão por ele autorizado, ou por meio de entidade de classe, sindicato, associação, cooperativa, dentre outros, ao qual seja filiado.

Neste estudo, trabalho com a perspectiva de que a queima prévia de cana-de-açúcar prejudica a saúde da população, as condições de vida e de trabalho, e do meio ambiente. O modelo de produção sem queima se mostra economicamente viável atualmente, devido ao avanço da tecnologia de colheita mecanizada.

Com a posição adotada neste estudo, também me coloco em conformidade com as demandas da sociedade civil organizada, representada por organizações não governamentais (ONGs) ambientalistas nacionais e internacionais, como a Pastoral do Migrante, Imaflora, World Wildlife Fund (WWF, 2008), Greenpeace, The Nature Conservancy (TNC), Conservação Internacional (Cl), Instituto Socioambiental (ISA) e Amigos da Terra. Elas exercem continuamente pressão para que a produção de cana-de-açúcar respeite os direitos humanos e não destrua o meio ambiente. Procuro, dessa forma, colaborar para tornar realidade a 'civilização da biomassa', ou seja, o almejado ecodesenvolvimento, com base na biomassa. (Abramovay, 2009). 


\subsection{Poluição do ar e saúde}

Em escala mundial, a utilização doméstica de combustíveis sólidos (carvão, lenha, resíduos) é a mais importante fonte de poluição do ar no interior das residências (Arbex et al., 2002). A exposição a subprodutos da combustão da biomassa de madeira está associada a numerosos problemas respiratórios (Alves, 2006; Arbex et al., 2004) e a um aumento da mortalidade e da carga da doença. Também está associada a um largo espectro de efeitos agudos e crônicos, cuja natureza varia de acordo com os constituintes dos poluentes. Em todo o mundo, estudos epidemiológicos e toxicológicos desenvolvidos em diversas instituições de pesquisa reforçam a premissa de que a exposição aos poluentes atmosféricos está associada a efeitos adversos sobre a saúde, como doenças do aparelho respiratório, cardiovasculares e até câncer (Bell et al., 2011; Arbex et al.,2010, 2007, 2004, 2000).

A maior parte dos estudos sobre poluição por material particulado se refere à sua ocorrência em área urbana, e não por queimadas a céu aberto. $\mathrm{Na}$ área rural, esse tipo de queimada é geralmente proveniente de fontes móveis, muitas vezes não controladas, como a queimada em pastos ou a queima prévia da palha cana-de-açúcar.

\subsubsection{Material particulado e doenças respiratórias}


O material particulado, MP, é o poluente que apresenta maior toxidade, em ambiente aberto ou fechado, sendo por isso o mais estudado. Ele é uma mistura de partículas líquidas e sólidas em suspensão no ar (Cançado et al., 2006), cuja deposição e remoção vão depender da sua composição e tamanho. As partículas são divididas quanto ao tamanho, em dois grupos: partículas grandes (coarse mode), com diâmetro entre $2,5 \mu \mathrm{m}^{12}$ e $10 \mu \mathrm{m}$, emitidas pela combustão controlada, dispersão mecânica do solo ou por outros materiais da crosta terrestre (pólen, esporos e outros materiais biológicos também se encontram nessa faixa de tamanho); e partículas pequenas (fine mode), com diâmetro menor que $2,5 \mu \mathrm{m}$.

A composição do material particulado atmosférico associado à queima da palha da cana-de-açúcar inclui partículas finas ácidas, tais como nitratos secundários, sulfatos e espécies orgânicas (Allen et al., 2004), além do Black Carbon ${ }^{13}$ (Lara et al., 2005), que faz parte tanto do particulado fino, como do grosso. O Black Carbon desempenha um importante papel na absorção da radiação solar e, então, pode aumentar o aquecimento atmosférico quando está em concentração elevada.

No caso da cana-de-açúcar, a influência da emissão de poluentes pela queima da palha de cana-de-açúcar e a composição do aerossol foi bem estudada por pesquisadores do Centro Nacional de Energia Nuclear na Agricultura, Piracicaba - SP (CENA) (Lara et al, 2005), de abril de 1997 a março de 1998. O local de amostragem, ao contrário das estações da

\footnotetext{
${ }^{12}$ Unidade $=$ Micrômetro .

${ }^{13}$ Espécies de carbono particulado que absorve eficientemente a radiação. $O$ termo criado em português para Black Carbon corresponde a "negro de fumo". No entanto, adotou-se o termo em inglês, pois é a forma comumente encontrada na literatura.
} 
CETESB no interior, era localizado na estação meteorológica da Escola Superior de Agricultura Luiz de Queiroz da Universidade de São Paulo (ESALQ-USP). Esse local se encontra a cerca de $4 \mathrm{~km}$ do centro de Piracicaba e a menos de $1 \mathrm{~km}$ da plantação de cana-de-açúcar mais próxima. Amostras foram coletadas, abrangendo o período com e sem queima prévia de cana-de-açúcar. As partículas denominadas inaláveis devido ao seu tamanho, foram separadas em duas frações: partícula fina, $\mathrm{PM}_{2,5}(<2,5 \mu \mathrm{m})$; e grossas (coarse particulate mode - CPM) PM $(2,5 \mu \mathrm{m}<$ e > 10 $\mu \mathrm{m})$. Concluiu-se que as concentrações médias de $\mathrm{PM}_{2,5}, \mathrm{CPM}$, Black Carbon e seus elementos químicos eram estatisticamente mais altos na estação seca (queima), do que na chuvosa (sem queima). Os resultados da análise de componentes principais mostrou de três a quatro fontes diferentes para $\mathrm{PM}_{2,5}$ e CPM, respectivamente. A principal fonte de $\mathrm{PM}_{2,5}$ encontrada foi a cana-de-açúcar queimada, representando $60 \%$; a poeira do solo respondeu por 14\%, e as indústrias e queima de óleo combustível (veículos) contribuíram com 12\% cada um. Segundo os autores do estudo, a concentração de $\mathrm{PM}_{10}$ durante a estação seca, na região de Piracicaba, era semelhante aos valores observados em Rondônia, na Bacia Amazônica, local onde ocorre extenso desmatamento associado a incêndios florestais (Artaxo et al., 2002). Observou-se também uma concentração bem superior à verificada na área metropolitana de São Paulo. No entanto, durante a estação chuvosa, os valores de $\mathrm{PM}_{10}$ em Piracicaba eram mais elevados que os de Rondônia e similares aos encontrados na região metropolitana de São Paulo. A média anual de $\mathrm{PM}_{10}$ encontrada em torno de Piracicaba foi ligeiramente maior 
do que o padrão vigente à época no país, $50 \mu \mathrm{g} / \mathrm{m}^{3}$. As partículas grossas dominavam a porção de $\mathrm{PM}_{10}$ e, possivelmente, estavam associadas à queima de palha de cana-de-açúcar na grande área de solos expostos em torno de Piracicaba. A queima, durante o período da colheita, emite partículas grossas e promove a ressuspensão da poeira do solo (Lara et al., 2005).

\subsubsection{Ação das partículas no sistema respiratório}

A qualidade do ar é um dos fatores essenciais à manutenção da saúde, quando considerado o sistema respiratório. A maioria dos poluentes tóxicos ambientais penetra no organismo humano por meio do ar inalado. Considerando que uma pessoa adulta em repouso tem ventilação pulmonar de cerca de 8.640 litros por dia, a poluição do ar apresenta importante efeito cumulativo, devendo-se levar em conta o tempo de exposição, o padrão respiratório e a solubilidade do agente químico envolvido. O nariz 'filtra' impurezas do ar, mas, nos casos de obstrução nasal, a respiração bucal é ativada, sendo nociva ao sistema respiratório. A capacidade de o organismo remover material particulado depende do tamanho e de outras propriedades físicas das partículas (Manço, 1992).

Assim, as partículas maiores de $10 \mu \mathrm{m}$ ficam eficientemente retidas nas narinas, enquanto que os menores de $2,5 \mu \mathrm{m}$ atingem as porções mais profundas do sistema respiratório. Elas transpõem a barreira epitelial, atingem o interstício pulmonar e são responsáveis pelo 
desencadeamento de processo inflamatório, conforme a Figura 3, a seguir.

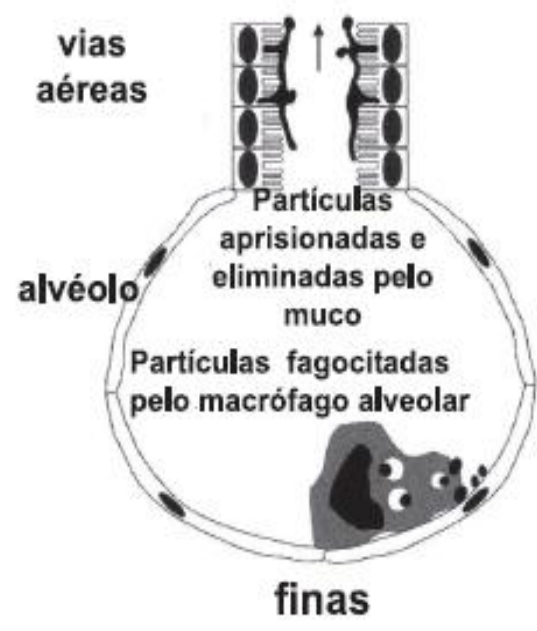

finas

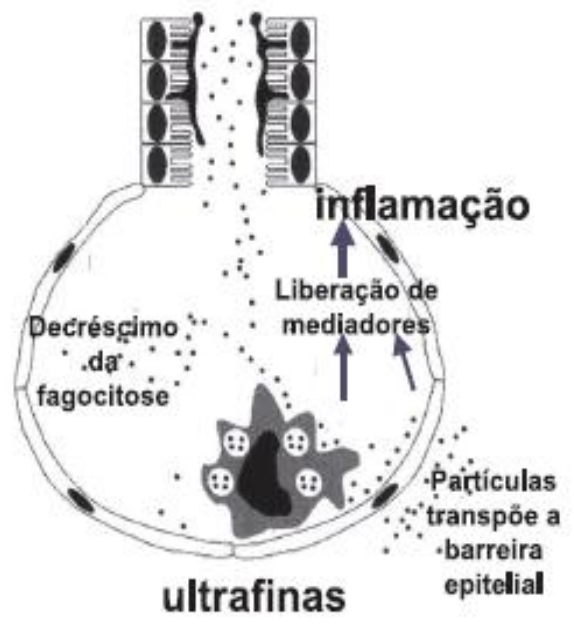

Donaldson e col, 2001

Fonte: Arbex, 2004.

Figura 3. Representação esquemática dos eventos hipotéticos após exposição às partículas ultrafinas (direita) quando comparado com a exposição a partículas finas (esquerda)

A inflamação crônica da árvore brônquica pode levar a quadros de doença pulmonar obstrutiva crônica (DPOC), enquanto que a destruição do parênquima pode causar enfisema. O acúmulo de muco na árvore brônquica predispõe aos episódios de infecção do trato respiratório.

\subsubsection{Estudos epidemiológicos sobre poluição do ar e saúde}

Grandes episódios de poluição do ar ocorreram no Vale do Meuse, na Bélgica, em 1930 (Fircket, 1931) e em Donora, nos Estados Unidos, em 1948 (Ciocco e Thompson, 1961), sendo associados a efeitos na saúde. No entanto, as pesquisas sobre associação entre poluição do ar e 
saúde humana só tiveram grande impulso após episódio ocorrido em Londres, no inverno de 1952 (Krewski et al., 2003), quando, em um intervalo de quatro dias, concentrações atmosféricas de PTS (partículas totais em suspensão) oscilaram entre $1,98 \mathrm{mg} / \mathrm{m}^{3}$ e $2,65 \mathrm{mg} / \mathrm{m}^{3}$ e de $\mathrm{SO}_{2}$ entre $0,94 p p m$ e 1,26ppm, sendo acompanhadas por 4.000 mortes, número muito superior ao esperado, principalmente por agravamento de doenças respiratórias. Logan (1952) demonstrou que níveis elevados de poluição do ar por partículas do ambiente provocam aumentos imediatos e dramáticos na mortalidade, principalmente em idosos.

Nesta breve revisão da literatura sobre o tema poluição do ar e saúde, apresento estudos considerados relevantes para a compreensão da importância do tema do presente estudo. A seguir, teço considerações a respeito de alguns estudos internacionais sobre poluição do ar; depois, estudos realizados no Brasil, passando pela descrição de estudos de poluição em geral e sendo mais específica abordo a poluição da queima de biomassa de palha da cana-de-açúcar no Estado de São Paulo, Brasil.

Dois estudos de coorte prospectivos, envolvendo milhares de indivíduos - a Harvard Six Cities Study (Dockery et al., 1993) e o Estudo da Sociedade Americana do Câncer (Pope III et al., 1995) - serviram como evidências para a Agência de Proteção Ambiental dos EUA (Environmental Protection Agency-EPA) estabelecer os primeiros padrões de qualidade do ar para partículas finas, menores que $2,5 \mu \mathrm{g}$ de diâmetro aerodinâmico (Krewski et al., 2005).

O primeiro é um estudo de coorte sobre os efeitos de longo prazo dos poluentes atmosféricos sobre a saúde. Os participantes foram 
selecionados aleatoriamente, a partir de seis cidades norte-americanas que tinham uma ampla variação de níveis de material particulado e gases poluentes. O inquérito inicial (que começou em 1974) centrou-se nas mudanças dos sintomas pulmonares e da função pulmonar. Os principais resultados dessas análises, para todas as causas de mortalidade, foram o aumento das mesmas em associação ao aumento das concentrações de partículas inaláveis, partículas finas e sulfato. Como resultado dessas descobertas em população limitada, os investigadores originais consideraram fazer uma análise semelhante, mas com uma população de estudo maior. Em colaboração com a Sociedade Americana de Câncer (American Cancer Society, ACS), foi usado o banco de dados do Cancer Prevention Study II da ACS (CPS-II) para analisar mortalidade e poluição do ar por partículas nos Estados Unidos (Pope III et al., 1995).

O Estudo da ACS é uma coorte prospectiva, iniciada em 1982, incluindo aproximadamente 1,2 milhão de homens e mulheres recrutados de todos os 50 estados dos EUA, o Distrito de Columbia e Porto Rico. Os principais resultados dessas análises mostraram que, para ambos os sexos, níveis médios mais elevados de sulfato foram significativamente associados ao aumento da mortalidade por todas as causas, dentre elas câncer de pulmão e doença cardiopulmonar.

No Brasil, Marcilio e Gouveia (2007) realizaram estudo abrangente, coletando informações das sete maiores cidades do país. Com base em estudos de séries temporais, foi estimado o impacto da poluição atmosférica urbana na saúde de idosos ( $\geq 65$ anos) e crianças (> cinco anos) pelo cálculo do coeficiente de concentração-resposta (C-R), 
associado a mudanças na concentração de $\mathrm{PM}_{10}$, e estimados os números de óbitos e internações hospitalares associados à poluição do ar.

Esses autores, juntamente com técnicos do município de São Paulo (Gouveia et al., 2006), realizaram estudo ecológico de séries temporais naquela cidade, observando o número de internações hospitalares por doenças respiratórias e cardiovasculares em crianças e idosos em relação a níveis diários de poluição do ar. Utilizaram modelos aditivos generalizados em regressão de Poisson. Todos os poluentes, com exceção do ozônio, apresentaram associação estatisticamente significativa com internações por doenças respiratórias e cardiovasculares. Um aumento de $10 \mu \mathrm{g} / \mathrm{m}^{3}$ em partículas inaláveis foi associado a um aumento de $4,6 \%$ nas internações por asma em crianças e de $4,3 \%$ nas internações por DPOC, e 1,5\% para a doença isquêmica do coração em idosos. As associações foram consistentes com a literatura e indicaram que os níveis de poluição do ar na cidade tinham impacto negativo sobre a saúde da população.

Os efeitos da exposição ao material particulado estão bem relatados em uma revisão de Pope III et al. (1995). Ela contém oitenta estudos (publicados a partir de 1985) em várias cidades do mundo, desde lugares de clima frio a de clima quente. Muitos desses estudos mostram associação estatisticamente significante entre hospitalizações ou visitas a serviços de saúde por doença respiratória e aumento da poluição por material particulado em séries temporais curtas. Os autores identificaram efeitos da mudança no curto prazo da exposição à poluição por material 
particulado sobre a mortalidade diária. Verificaram que, embora as muitas formas diferentes de medir a poluição por material particulado dificultem a comparação de resultados, a maior parte dos estudos sugeria que um aumento de $10 \mu \mathrm{g} / \mathrm{m}^{3}$ na concentração de $\mathrm{PM}_{10}$ estava associado ao aumento na mortalidade diária de $0,5 \%$ a $1,5 \%$. Eles estimaram que cerca de $2 \%$ a $9 \%$ da mortalidade total estava associada à poluição por material particulado. Todavia, os autores consideraram importante o fato de esse tipo de estudo não permitir a avalição das exposições individuais dos sujeitos (por exemplo, uso de tabaco), e que a força da associação entre mortalidade e material particulado era sensível às especificações do modelo e às características econômicas e demográficas, além da escolha das áreas de estudo.

Gouveia e Fletcher (2000a) desenvolveram dois estudos na cidade de São Paulo, no período de novembro de 1992 a setembro de 1994, usando contagens diárias de internações hospitalares por doenças respiratórias, juntamente com os níveis diários de variáveis meteorológicas e poluentes do ar $\left(\mathrm{PM}_{10}, \mathrm{SO}_{2}, \mathrm{NO}_{2}, \mathrm{O}_{3}\right.$ e $\left.\mathrm{CO}\right)$, analisados por meio de regressão de Poisson. Os modelos finais foram ajustados para os efeitos das tendências temporais, padrões sazonais, dias da semana, feriados, fatores meteorológicos e correlação serial.

Em outro estudo de série temporal (Gouveia e Fletcher, 2000b), os mesmos pesquisadores analisaram a influência do fator idade e do nível socioeconômico na modificação de associações entre mortalidade e poluição do ar, medindo a mortalidade por todas as causas, causa respiratória e causa cardiovascular. O modelo usado foi de regressão de 
Poisson, ajustado para padrões temporais, meteorológicos e de autocorrelação. As associações entre poluentes do ar e mortalidade em crianças menores de 5 anos de idade não foram estatisticamente significativas. O aumento no risco de morte de acordo com a idade foi significativo, sendo os efeitos mais evidentes em indivíduos com mais de 65 anos e em áreas com maior nível socioeconômico. Os resultados mostraram evidência de associação entre a poluição do ar e a mortalidade, mas com magnitude menor do que a encontrada em estudos semelhantes na Europa e na América do Norte. Mostraram, ainda, que os idosos apresentavam maior risco de mortalidade associada à poluição do ar, considerando que "Esta complexidade deve ser levada em conta na avaliação do risco à saúde baseada em estudos de séries temporais" (Gouveia e Fletcher, 2000b, p.750).

Em 2003, foi publicado estudo ecológico sobre intervenção ocorrida em Dublin, Irlanda (Clancy et al., 2003), relativa à eliminação da queima do carvão betuminoso usado para aquecimento das lareiras dos domicílios. Foram comparados dados de poluição do ar e mortalidade 72 meses antes da eliminação da queima do carvão (1984 a 1990) e depois dela (1990 a 1996). A troca do combustível resultou em $70 \%$ de redução na poluição por material particulado, medido pelo Black Smoke. As taxas de mortalidade por causas respiratórias e cardiovasculares, ajustadas pelo tamanho da população e faixa etária, declinaram de 15,5\% a 10,3\%, respectivamente. Os resultados sugeriram que o material particulado tinha um efeito danoso ao sistema cardiopulmonar. Além disso, as estimativas de efeito, extrapoladas a partir desse estudo, foram substancialmente 
maiores do que aquelas obtidas a partir de estudos de séries temporais diárias de mortalidade e estimativas do efeito de abordagem em longo prazo, sugerindo que séries temporais de curto prazo ou estudos episódicos não captavam adequadamente os efeitos cumulativos da exposição à poluição.

Em 2009, Pope III et al. (2009) usaram o desenho de estudo ecológico e dois cortes transversais para avaliar o impacto da redução da poluição do ar na expectativa de vida em 211 municípios, de 51 áreas metropolitanas dos Estados Unidos. Compararam-se dados ambientais em relação à expectativa de vida em dois períodos distintos, compreendidos entre o final dos anos 1970 e início de 1980, e um período posterior, no final da década de 1990 e início da de 2000. Ajustou-se o modelo para variáveis socioeconômicas, características demográficas e variáveis proxy para o tabagismo. Os autores estimaram modelos cuja variável resposta era a diferença entre a expectativa de vida calculada para os dois períodos. A mesma abordagem foi aplicada para as variáveis explicativas. O aumento médio na expectativa de vida estimada para os estados foi de 2,72 anos relativo a uma redução média de $\mathrm{PM}_{2,5}$ de $6,52 \mu \mathrm{g} / \mathrm{m}^{3}$

\subsubsection{Estudos epidemiológicos sobre poluição da queima de palha de cana-de-açúcar e seus efeitos sobre a saúde}

Em vista da importância da cultura canavieira no Brasil, era esperado que existissem muitos estudos para avaliar os efeitos da 
queima prévia da palha de cana-de-açúcar na saúde da população que vive nas cidades próximas e no entorno. Essa não é a realidade, como relata Ribeiro (2008), ainda que alguns trabalhos tenham sido feitos, sendo a maior parte em cidades canavieiras do Estado de São Paulo.

Em 1995, na cidade de Araraquara, Arbex et al. (2000) realizaram pesquisa epidemiológica, colhendo como indicador de saúde o número de visitas diárias dos pacientes que necessitavam de terapia de inalação em um dos principais hospitais da cidade. A poluição foi medida diretamente, por meio da colocação de quatro recipientes (bandejas) em pontos estratégicos da cidade, e o material particulado coletado foi pesado (artifício usado devido à falta de dados). As medidas foram feitas apenas no período mais intenso de queima, nos meses de maio a agosto. Os dados do peso dos sedimentos associados ao número de visitas e controlados para sazonalidade, temperatura, dia da semana e chuva, foram inseridos em modelos de regressão de Poisson e apresentaram uma relação significativa dose-dependente. Nos dias mais poluídos, o risco relativo $(\mathrm{RR})$ do número de visitas hospitalares associado a um aumento de 10 $\mathrm{gg}$ no peso do sedimento foi de 1,09 (IC95\%:1,01-1,19), e o RR para necessitar de terapia de inalação foi de 1,20 (IC95\%:1,031,39). Esses resultados demonstraram haver associação entre a queima de cana-de-açúcar e efeitos deletérios à saúde da população exposta.

Na mesma cidade, um novo experimento foi realizado, um estudo ecológico de série temporal de 2003 a 2004 (Arbex et al., 2007), observando-se o período com e sem queima, com aferição da 
concentração diária de Partículas Totais em Suspensão, PTS ${ }^{14}\left(\mu \mathrm{g} / \mathrm{m}^{3}\right)$. A temperatura e umidade usadas foram as médias diárias obtidas no aeroporto local. O modelo de regressão de Poisson usado teve como variável dependente o número diário de internações hospitalares por asma (CID-10, J15) obtidas no principal hospital de Araraquara, e como variável independente a concentração diária de PTS. A concentração de PTS mostrou ter um efeito agudo sobre as admissões por asma, um dia após o aumento da concentração, permanecendo praticamente inalterada nos quatro dias seguintes. Um aumento de $10 \mu \mathrm{g} / \mathrm{m}^{3}$ na média móvel de cinco dias (lag 1-5) das concentrações de PTS foi associado a um aumento de 11,6\% (IC95\%:5,4-17,7) nas admissões hospitalares por asma.

Nesse mesmo experimento, foi estudado outro desfecho (Arbex et al., 2010): as admissões hospitalares por hipertensão (CID-10,115) de indivíduos de todas as idades. A concentração de PTS também apresentou efeito sobre as internações por hipertensão observadas um dia após o aumento da queima, sendo que, após dois dias, esse efeito se manteve praticamente inalterado. Um aumento de $10 \mu \mathrm{g} / \mathrm{m}^{3}$ na média móvel de três dias da concentração de PTS defasado em um dia conduziu a um aumento nas internações hospitalares relacionadas a hipertensão, durante o período da queima prévia, de 12,5\% (IC95\%:5,6\%-19,9\%), quase $30 \%$ maior do que durante o período sem queima.

Em Piracicaba, outra cidade canavieira do Estado de São Paulo, Cançado (2003) também analisou a influência da queima da cana-de-

\footnotetext{
${ }^{14}$ Partículas Totais em Suspensão.
} 
açúcar no sistema respiratório. Ele fez uso dos dados de um grande experimento de pesquisadores do CENA (Lara et al., 2005), já citado, onde foi coletado material particulado proveniente da queima da cana-deaçúcar, separado pela granulometria, e composição química. Ao mesmo tempo, Cançado coletou os dados de admissão hospitalar por causa de doenças respiratórias em crianças ( $<13$ anos de idade) e idosas (> 64 anos de idade). Foi usada uma modelagem linear generalizada e controlado para os efeitos sazonais e temporais se obteve uma associação entre aumento de $10,2 \mu \mathrm{g} / \mathrm{m}^{3}$ nas partículas de $P M_{2,5}$ e de $42,9 \mu \mathrm{g} / \mathrm{m}^{3}$ nas de $\mathrm{PM}_{10}$ com aumentos de $21,4 \%$ (IC95\%:4,3-38,5) e 31,0\% (IC95\%:1,25-60,21) nas internações hospitalares em crianças e idosos, respectivamente. No período da queima, existiam 3,5 vezes mais internações do que no período sem queima.

Em uma outra cidade canavieira paulista chamada Espírito Santo do Turvo, mas com apenas 3.600 habitantes de base econômica rural, sem indústrias, nem muitos carros, foi desenvolvido um outro estudo interessante (Ribeiro e Pesquero, 2010). A cidade foi escolhida por não existir outra atividade econômica que pudesse confundir o efeito da poluição devido à queima de cana-de-açúcar (potenciais efeitos de confusão) de modo que interferisse na análise dos efeitos sobre a saúde respiratória de crianças. O Laboratório de Qualidade do Ar da Faculdade de Saúde Pública da USP realizou medições de Material Particulado Total em Suspensão (PTS), Material Particulado Inalável $\left(\mathrm{PM}_{10}\right)$ e Dióxido de Nitrogênio $\left(\mathrm{NO}_{2}\right)$ durante os períodos de 8 a 12 de novembro de 2004, e 6 a 12 de julho de 2005. Os amostradores foram localizados na Escola 
Municipal do Campo, situada na zona urbana de Espírito Santo do Turvo. E foram aplicados questionários para avaliar a morbidade respiratória referida, em alunos de 11 a 13 anos. Os resultados dos questionários foi comparado aos obtidos previamente em Juquitiba, município da Região Metropolitana de São Paulo, caracterizado pela concentração de Parques e de vegetação nativa de mata atlântica preservada. A medição de poluentes, realizada em dias em que havia queima de cana-de-açúcar mostrou valores inferiores ao padrão de qualidade do ar brasileiro (Resolução CONAMA no 03/90) (Anexo 6). Entretanto, foram observadas altas prevalências de sintomas e doenças respiratórias nas crianças de 11 a 13 anos. Como não existiam outros fatores que pudessem explicar essa alta prevalência, a indicação foi de que a poluição advinda da presença da agroindústria da cana-de-açúcar seria suficiente para constituir um fator de risco à saúde respiratória de crianças, mesmo quando o nível de poluição medido estava em conformidade com os padrões brasileiros de qualidade do ar.

São poucos os estudos que usam a população inteira do estado como objeto de análise. No estudo Cana, incêndios e saúde respiratória em São Paulo, Brasil: estudo de caso sobre as implicações sociais da produção de Agroenergia (Uriarte et al., 2009), a unidade de análise foi o território dos municípios de São Paulo, sendo o fator de exposição os focos de queima, obtidos por meio de imagens de satélite do INPE, no ano de 2003. Como desfecho, foram analisados dados sobre a saúde respiratória de idosos ( $\geq 60$ anos) e crianças (<10 anos), medidos através de dados secundários mensais de morbidade e mortalidade por doenças 
respiratórias no ano de 2003, extraídos do Sistema de Informações sobre Mortalidade (SIM) e Sistema de Informações Hospitalares (SIH) do Sistema Único de Saúde (SUS), Ministério da Saúde (MS), disponibilizados pelo departamento de informática do Sistema Único de Saúde (DATASUS). As taxas foram padronizadas pelo tamanho da população em cada faixa etária do Censo de 2000, e foram usados dados climáticos mensais do ano de 2003: A precipitação total e a média de temperatura máxima. Foi construído um modelo de regressão logística de efeitos mistos para entender a relação de dependência entre a saúde respiratória e a qualidade do ar. A área da cultura canavieira de cada município em 1995 foi a base para expressar o efeito crônico de queimadas anteriores nas doenças respiratórias. A variação mensal na ocorrência de queimadas foi diretamente associada à morbidade respiratória para idosos e crianças. O estudo concluiu que, no Estado de São Paulo, aproximadamente $1,8 \%$ das internações por doenças respiratórias de crianças e idosos eram atribuídas às queimadas. Além disso, para os municípios com mais de $50 \%$ do território ocupado com cana-de-açúcar, o percentual de internações por doenças respiratórias atribuídas à queimada havia aumentado em $15 \%$ e $12 \%$, respectivamente, entre os idosos e as crianças (idosos: 16 dos 109 casos; crianças: 93 de 768 casos). Um aumento de 209 casos de internação em crianças foi atribuído também à exposição crônica (passada) às queimadas de cana-de-açúcar, o que sugere que $38 \%$ do total de casos respiratórias na infância podiam ser atribuídos à exposição a queimadas recentes ou ao efeito crônico (passado). 
Em outro estudo epidemiológico ecológico de Lopes e Ribeiro (2006), através do uso de dados secundários e ferramentas do sistema de informações geográficas (SIG) para analisar uma possível correlação espacial entre produtos das queimadas de cana-de-açúcar e incidência de problemas respiratórios no Estado de São Paulo, no período de 2000 a 2004. A Região Administrativa de Araraquara foi selecionada para análise por possuir alta concentração da cultura. Pelo uso de mapeamento dos eventos focos de queima e de internações do Sistema de Informações Hospitalares (SIH/SUS) e de método de análise espacial, concluíram pela maior incidência de doenças respiratórias nas regiões onde existe a prática de queimadas.

É um dado a considerar o fato de o Brasil ser o maior produtor de cana-de açúcar, atrás dele vindo a Índia, a China e a Indonésia (DinardoMiranda et al., 2008), todos países considerados não desenvolvidos. Isso pode explicar, em parte, a falta de estudos internacionais sobre os efeitos da queimada de cana-de-açúcar. Afinal, a cultura não se adapta ao clima temperado ou seco, e, portanto, esse tipo de queimada não é prática comum em países temperados e desenvolvidos. Apenas no sul dos Estados Unidos se cultiva cana-de-açúcar em alguns estados, como a Flórida, por exemplo. Lá se usa a queima da palha e de restos da cultura, mas existe uma legislação rigorosa, visando a seu controle. No Estado de Louisiana, apesar de a colheita ser totalmente mecanizada, queima-se a palha para eliminação de resíduos e, de 1998-1999, foi realizada uma pesquisa exploratória (Boopathy et al., 2002), em que foi medido o número de pacientes hospitalizados por asma. Foi encontrado um 
aumento de três vezes no valor do desvio padrão da média de hospitalizações durante os meses de queima de palha da cana-de-açúcar.

Quanto ao uso do fogo na agricultura, além da queima na cultura de cana-de-açúcar, no Brasil, a população está sujeita à um problema paradoxal, que são as queimadas em cidades da Amazônia, onde são verificadas altas taxas de internação e mortalidade por doenças respiratórias no período de seca. Nessa época, a floresta derrubada e os pastos são queimados para renovação, e, desse modo, o nível de fogo e fumaça atinge magnitudes que chegam a prejudicar o funcionamento dos aeroportos (Sá et al., 2007).

Atualmente, existem vários estudos demonstrando esse problema, sendo comum o uso de séries temporais. Na cidade de Rio Branco, Acre (Ignotti et al., 2007), foi realizado um trabalho sobre os impactos da poluição do ar provocada pelas queimadas. O estudo demonstrou que, no período de 1998 a 2004, a taxa de mortalidade aumentou em cerca de $20 \%$ nos meses com queimada, quando comparados aos meses sem ela. Na mesma região, o subprojeto interinstitucional Avaliação dos efeitos da queima de biomassa na região do arco do desmatamento à saúde humana, coordenado pela Escola Nacional de Saúde Pública (ENSP/Fiocruz) (Carmo et al., 2010) usou os mesmos indicadores de morbidade e mortalidade utilizados no presente estudo. Realizou uma regressão de Poisson via modelos aditivos generalizados e obteve como resultado evidências de que o incremento de $10 \mu \mathrm{g} / \mathrm{m}^{3}$ nos níveis de exposição ao material particulado estaria associado a aumentos de 2,9 e 2,6\% nos atendimentos ambulatoriais por doenças respiratórias em 
crianças, realizados no $6^{\circ}$ e $7^{0}$ dias subsequentes à exposição à queimada. 


\section{CONTEXTO}

A cultura da cana-de-açúcar faz parte da história do Brasil desde o período colonial, com fases de crescimento e de crise, mas, como apresenta boa adaptação agronômica na maior parte do território brasileiro, está em constante expansão. Dados da Food and Agriculture Organization (FAO) mostram que, de 1960 a 2011, a área plantada com cana-de-açúcar no país aumentou de 1,4milhões para 9,6 milhões de hectares. Portanto, a taxa média de aumento foi de quase $120 \mathrm{mil} \mathrm{ha/ano}$ (FAOSTAT, 2011), exceto no período entre 1985 e 1990, quando a taxa foi menor.

Este estudo concentra atenção no impacto da recente expansão da cultura da cana-de-açúcar no Estado de São Paulo, considerando o aumento da demanda interna pelo etanol, associado ao lançamento, em 2003, dos carros híbridos chamados flex, que funcionam a álcool ou à gasolina.

Atualmente, o Brasil é o maior produtor e exportador de açúcar, e está em segundo lugar na produção de etanol, em termos absolutos. No ano da realização deste estudo 2010, houve produção de 27,4 bilhões de litros de etanol de cana-de-açúcar, enquanto os Estados Unidos produziram 50,1 bilhões de litros, provenientes do milho. No entanto, o Brasil conseguiu atingir o maior percentual de substituição de gasolina por etanol - 44,5\%, enquanto os EUA atingiram apenas 9,5\% de substituição 
(Nastari, 2011). No país, o etanol combustível é consumido na forma de etanol hidratado, usado pela frota flex, e etanol anidro, adicionado à gasolina na proporção de $25 \%$ em volume, usado tanto pela frota flex quanto pela frota dedicada à gasolina (Nastari, 2011).

O motor do carro flex surgiu em 2003 e, desde então, inúmeros aperfeiçoamentos ocorreram, fazendo o tornar-se dominante no mercado e crescimento exponencial. O motor do veículo flex, funciona com qualquer mistura de gasolina e etanol, e os dois combustíveis ficam no mesmo tanque. A injeção se ajusta automaticamente, graças a sensores que analisam as emissões do veículo. O sucesso dos carros flex, e a obrigatoriedade, no país, de haver entre $20 \%$ e $25 \%$ de etanol na gasolina, fez com que o consumo do biocombustível superasse o de gasolina em 2008 - limiar do processo em que a política governamental para combustíveis, privilegiando a gasolina, passou a influenciar uma reviravolta no mercado. Hoje, ao mesmo tempo em que mais proprietários de carros flex podem optar pela gasolina, quase $90 \%$ dos veículos leves comercializados no Brasil são flex, dentre eles diversos modelos importados, produzidos com tecnologia flex em outros países para atender ao mercado brasileiro (Nigro e Szwarc, 2010).

A cadeia produtiva da cana-de-açúcar (Neves et al., 2009) foi calculada em US\$28,1 bilhões, o equivalente a $2 \%$ do Produto interno Bruto (PIB) do Brasil ou quase o PIB de um país como o Uruguai (US\$ 32 bilhões) (Neves et al., 2009).

A crise do Petróleo nos anos 1970 (em 1973 o preço do petróleo aumentou $300 \%$ em cinco meses) levou à criação do Programa Nacional 
do Álcool, ou Proálcool de $1975^{15}$, que tornou o país pioneiro no uso em larga escala do etanol como combustível veicular. Com ele, foi criado um parque industrial de produção de bens de capital para a agroindústria sucroenergética e, atualmente, o país é exportador dessa tecnologia para essa indústria em outros países. Tanto a tecnologia usada na agroindústria canavieira como a desenvolvida pela indústria automobilística, para o uso do etanol - por exemplo, a dos veículos flexfuel -, foram desenvolvidas nacionalmente. Dessa forma, existem atualmente condições conjunturais favoráveis e boas perspectivas de ampliação do Complexo Agroindustrial Canavieiro (CAI), inclusive com atração de capital e parceiros internacionais (Alves e Alves, 2000).

O etanol precisa se tornar uma commodity energética global para que a expectativa de desenvolvimento econômico depositada na produção de cana-de-açúcar se realize, e o setor, agora denominado sucroenergético, possa expandir sua produção e atingir amplamente o mercado internacional. Para isso, diferentemente dos tempos da colônia escravocrata exportadora de açúcar, a produção do etanol de cana-deaçúcar deve estar em conformidade com o nível internacional de exigências quanto à qualidade do produto e ao cumprimento de regras internacionais relativas ao mercado de trabalho e à preservação do meio ambiente. Nesse sentido, o governo e o setor produtivo adotaram medidas, como o Zoneamento Agroambiental (ZAA) para o Setor Sucroalcooleiro no Estado, por meio da Resolução SMA-SAA no 04 de 18 de setembro de 2008 (Anexo 2).

\footnotetext{
${ }^{15}$ Decreto Federal no $76.593 / 1975$.
} 
Com o crescente aumento da demanda mundial por biocombustíveis e do interesse de empresas nacionais e internacionais em aportar recursos para produção de etanol no Brasil, o Governo Federal também necessitou adotar medidas para permitir que o investimento externo continuasse a fluir para o país. Desse modo, também estabeleceu um Zoneamento Agroecológico da Cana-de-açúcar por meio do Decreto nº 6.961 (Brasil, 2009), elaborado pela Empresa Brasileira de Pesquisa Agropecuária, Embrapa, e detalhado para cada estado. Com isso, o Estado brasileiro garantiu que novas plantações de cana-de-açúcar não ocupassem áreas de vegetação nativa, nem os biomas Pantanal e Amazônia, como se pode ver na Figura 4.

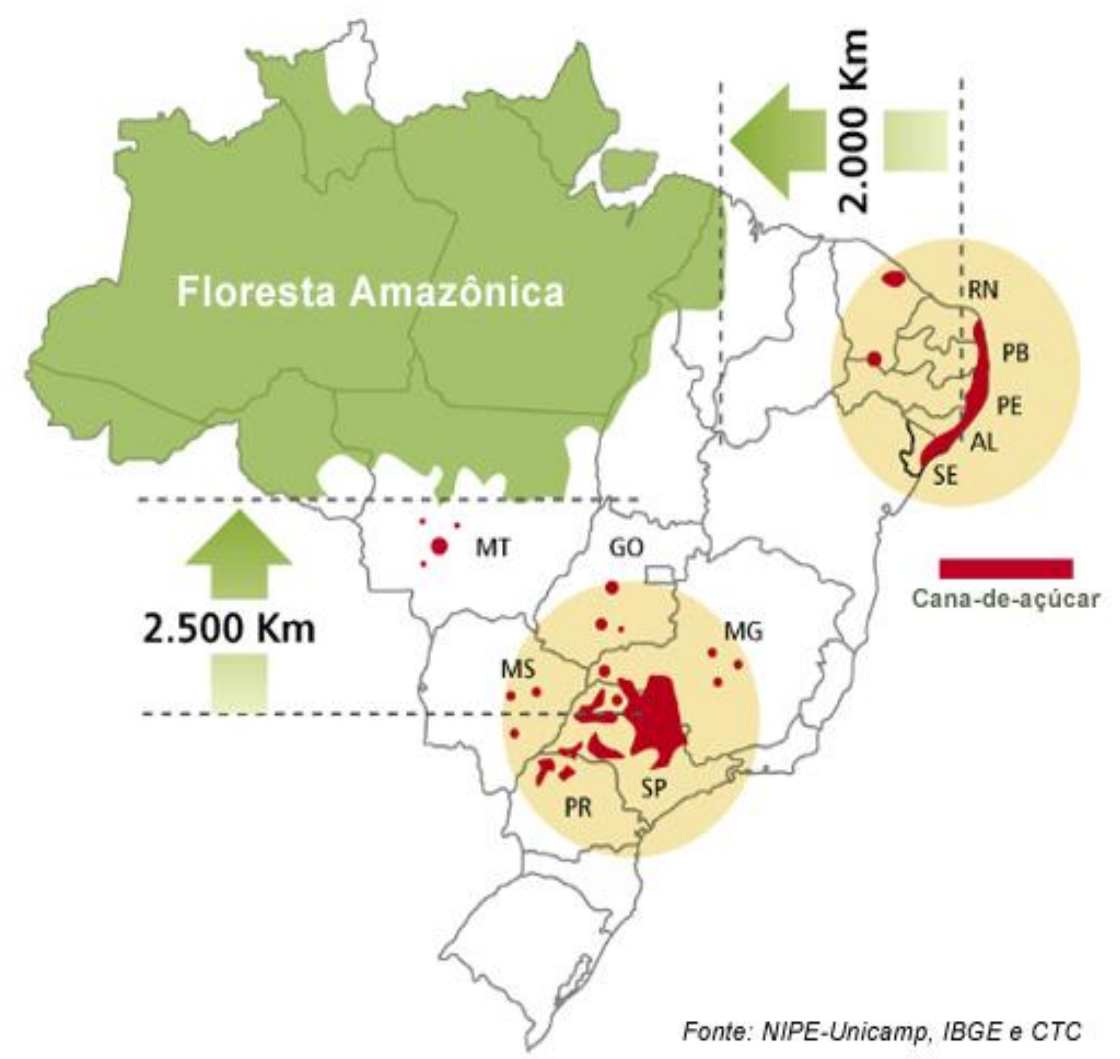

Figura. 4. Localização da cultura da cana-de-açúcar no Brasil 
Atualmente, existe em torno da produção de etanol um ambicioso programa de pesquisas e inovação tecnológica composta por entidades públicas e privada (Jank e Nappo, 2009). O Ministério da Agricultura estabeleceu, pelo Plano Nacional de Agroenergia 2006-2011 ${ }^{16}$, a produção de etanol como parte da estratégia de desenvolvimento do país. Essa política é fortalecida por diversos organismos. No nível federal, por exemplo, o Ministério da Ciência e Tecnologia (MCT) criou, em 2010, o Laboratório Nacional de Ciência e Tecnologia do Bioetanol (CTBE). Tratase de uma instituição articuladora de pesquisa externa que dispõe de infraestrutura para realização, por universidades e institutos de pesquisa públicos e privados, de projetos para a manutenção da liderança brasileira no setor de fontes renováveis de energia e de insumos para a indústria química, em especial para o fortalecimento da cadeia produtiva do bioetanol de cana-de-açúcar. Ele trabalha na fronteira do conhecimento. Por meio da Embrapa, o Governo Federal criou, no Distrito Federal, o Centro Nacional de Pesquisa em Agroenergia (CNPAE) ${ }^{17}$, que desenvolve pesquisas relacionadas ao biodiesel, ao biogás e a florestas energéticas $^{18}$, além das relacionadas ao etanol.

No nível estadual, o governo do Estado de São Paulo, criou em 2008 o Programa de Iniciativas em Bioenergia (Bioen), por meio da Fundação de Amparo à Pesquisa do Estado de São Paulo (FAPESP) que,

\footnotetext{
${ }^{16}$ Disponível em: ttp://www.embrapa.br/publicacoes/institucionais/agroenergia_miolo.pdf ${ }_{17}^{17}$ Disponível em: http://www.cnpae.embrapa.br/agroenergia_miolo1.pdf/view.

${ }^{18}$ Florestas energéticas são plantações florestais industriais, cultivos para a produção de energia.
} 
entre outras pesquisas, busca criar compostos de alto valor econômico a partir de substratos da cana-de-açúcar (Marques, 2012).

O setor privado dispõe, desde 1969, do Centro de Tecnologia Canavieira $(\mathrm{CTC})^{19}$ com destaque para o desenvolvimento de tecnologias que permitam a evolução da produção e do processamento da cana-deaçúcar. Este possui atualmente o maior banco de germoplasma de canade-açúcar, além de uma rede de pesquisa para melhoramento genético dessa cultura agrícola estratégica.

\subsection{Novo ciclo da cana-de-açúcar no Brasil}

A partir de 2002, o CAl iniciou um período de grande dinamismo, fazendo lembrar o período áureo do Proálcool (1974/1983). Atualmente, suas principais commodities - o açúcar e, principalmente, o álcool desfrutam de papel privilegiado na dinâmica do agronegócio brasileiro, graças aos fatores a seguir (Ramão et al., 2007).

- Excelentes perspectivas do comércio nacional e internacional, tanto para o açúcar quanto para o álcool;

- Fim de parte das barreiras europeias ao açúcar brasileiro;

- Elevação dos preços internacionais do petróleo, os quais, desde março de 2008, ultrapassaram a marca de US\$100.00 por barril e, em 2012, chegaram a mais de US $\$ 114.00$ por barril;

- Redução nas subvenções às exportações de açúcar na Europa, promovendo forte queda nos volumes exportados pelo bloco;

\footnotetext{
${ }^{19}$ Disponível em: http://www.ctcanavieira.com.br/.
} 
- Crescimento da demanda interna de álcool hidratado, ocasionado pelo sucesso dos novos modelos de automóvel lançados em 2003, movidos tanto a álcool quanto à gasolina, os flexfuel;

- Em 2004, o etanol passou a ser combustível de avião;

- Em 2009, foi lançada a motocicleta com essa tecnologia;

- Em 2010, ônibus movidos a etanol começaram a circular pelas ruas de São Paulo;

- Imposição de metas para redução das emissões de $\mathrm{CO}_{2}$ em muitos países signatários do Protocolo de Kyoto, tendo como uma questão central a preocupação com o aquecimento global, o que tem provocado crescimento na demanda externa por álcool anidro, fazendo-o despontar como uma nova commodity internacional;

- Incapacidade de os EUA terem condições de atender à sua própria demanda interna futura de álcool e tampouco à demanda externa, apesar de serem os maiores produtores mundiais de álcool de milho, e

- Baixos custos de produção das commodities açúcar e álcool - os custos de produção do açúcar e do álcool no Brasil são significativamente menores do que os de países que fabricam tais produtos, utilizando outras matérias-primas, como a beterraba ou o milho (Alves et al., 2008). 


\subsection{Colheita de cana-de-açúcar: tecnologia e mão de obra}

A colheita da cana-de-açúcar é decomposta em três atividades: o corte, o carregamento e o transporte, antes feito por burros, como mostra a Figura 5, a seguir.

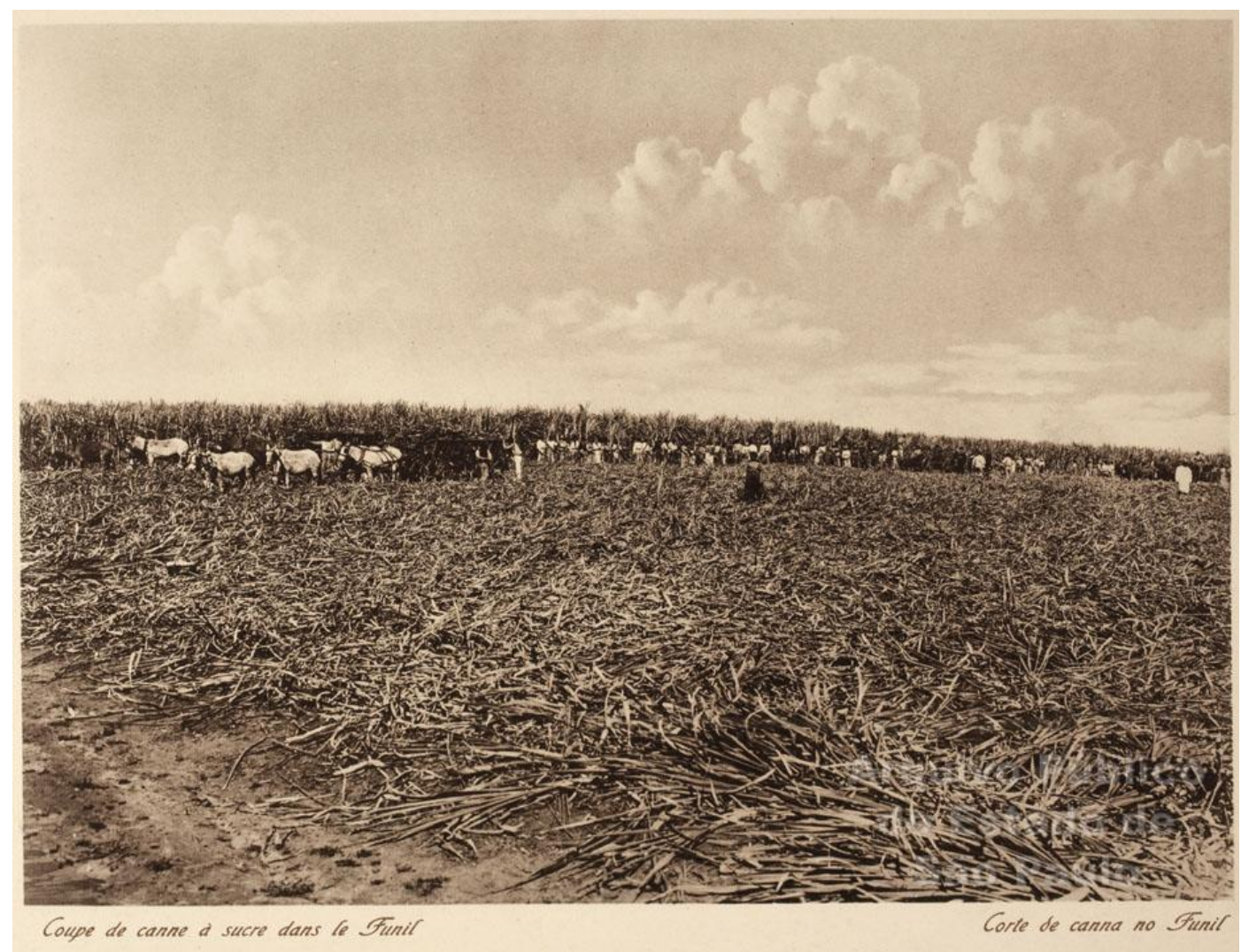

Fonte: Acervo fotográfico do Instituto Geográfico e Cartográfico de São Paulo.

Disponível em: http://www.igc.sp.gov.br/Produtos/aspectos_urbanos.html

Figura 5 - Corte de cana-de-açúcar enfeixada e transporte por tração animal

$\mathrm{Na}$ maioria das usinas brasileiras, a mecanização incidiu primeiramente sobre as duas últimas etapas e até meados da década de 1950, a palha de cana-de-açúcar não era queimada no campo, simplesmente porque sequer existiam máquinas carregadoras de cana- 
de-açúcar ${ }^{20}$. As folhas, então, eram usadas na confecção dos feixes de cana-de-açúcar (Alves, 1991). Os fardos formados por feixes eram transportados nas costas pelos próprios cortadores, ou em veículos de tração animal (Figura 5). Destes, passavam para os caminhões que transportavam a cana-de-açúcar até a usina. Tais características do corte inviabilizavam o plantio de talhões muito grandes, pois eram necessários muitos trabalhadores para cortar e carregar o produto no mesmo talhão ${ }^{21}$. Essa técnica só foi modificada pela introdução das carregadeiras, chamadas de guinchos, e dos caminhões de transporte.

Com o aumento da demanda externa e da necessidade de elevação da capacidade de produção das usinas, acompanhada de maior área plantada para abastecimento dessas, no final da década de 1950, a cana-de-açúcar passou a ser queimada antes do corte e deixou de ser enfeixada. Segundo Belik (1985) a primeira grande inovação introduzida na organização do trabalho no corte da cana-de-açúcar data dessa época, com a disseminação e a prática da queima das folhas para facilitar o corte. O aumento de produtividade foi resultado, principalmente, da facilidade de trabalho no canavial após a queima. Este, sem as folhas secas que atrapalhavam os movimentos e exigiam a limpeza do canavial após cada operação de corte, teve sua produtividade aumentada de 2,5 toneladas/dia para 4 toneladas/dia por trabalhador (Alves, 1991). Outro fator importante para o aumento da produtividade foi a divisão das tarefas

${ }^{20}$ Comunicação oral Professor, Caetano Ripoli (falecido).

${ }^{21}$ Talhão é a área da plantação delimitada pelos carreadores ou vias, por onde podem trafegar os caminhões e as máquinas agrícolas. Em geral, os talhões são retangulares, para facilitar o tráfego, mas, dependendo das condições do terreno, eles podem ter o formato de trapézios, losangos ou outro polígono qualquer. 
entre o corte e o carregamento, antes executados por apenas um trabalhador e, a partir desse período, por pessoas diferentes. Por sua vez, houve um aumento nas exigências para seleção desses trabalhadores que passaram a ser recrutados apenas entre os mais fortes e resistentes, para poder suportar a carga de trabalho extenuante. Nessa fase, teve início o pagamento por produção para os cortadores e carregadores, visando a incentivar o aumento da produtividade do corte manual, causando o aumento do ritmo e da extensão da jornada de trabalho - um aspecto negativo, pois, segundo Scopinho e Valarelli (1995), a introdução do pagamento do corte por produção intensificou o ritmo de trabalho até o limite da capacidade física dos cortadores. O aumento da renda do trabalhador com melhor produtividade provocou um efeito perverso, pois, dessa maneira, os cortadores e seus sindicatos passaram a defender a queima prévia da cana-de-açúcar como condição indispensável à manutenção de seus empregos e renda, concorrendo para que fosse estabelecido, nas convenções coletivas de trabalho da categoria, que o corte manual somente pudesse ser realizado com cana-de-açúcar queimada (Moraes, 2007). O motivo para isso é que a queima, além de aumentar a produtividade do trabalhador, elimina os insetos e animais ali existentes, reduzindo o número de acidentes durante o corte.

A substituição de carregadores pelos guinchos mecânicos ocorreu em diferentes épocas no Centro-Sul e no Nordeste, sendo que este deixou de enfeixar a cana-de-açúcar cortada apenas nos anos 1980, em consequência das greves que ocorreram em Pernambuco, em 1979 (Alves et al., 2000). 
Uma das primeiras atividades na cultura de cana-de-açúcar a ser mecanizada foi o transporte. Os caminhões utilizados no campo passaram a ser cada vez maiores para acompanhar o aumento da produtividade do corte e do carregamento, e para evitar a perda de sacarose, fato que costuma ocorrer devido à fermentação, principalmente quando a cana-de-açúcar é queimada, o que reduz a produtividade da fabricação de açúcar e do álcool.

A mecanização da atividade de colheita teve início somente no final dos anos 1970 (Silva, 2008), quando apareceram as primeiras colheitadeiras mecânicas. Como a produtividade das máquinas na época era mais baixa do que a atual, a colheita mecanizada acabava tendo um alto custo em comparação à colheita manual que usava mão de obra com baixa qualificação, excedente no país. No início, as novas máquinas eram usadas apenas como estratégia para forçar a redução dos salários dos cortadores (Graziano, 1981) e seu uso ficou restrito a algumas regiões do país e ao período de início da safra. Como já citado, o Proálcool resultou no surgimento de mais fornecedores de cana-de-açúcar ou canavicultores, promoveu investimentos no aprimoramento tecnológico. Desse modo, surgiram máquinas mais eficientes, que passaram a colher cana-de-açúcar sem queima ou queimada, ereta ou tombada. Além de cortar e picar a canade-açúcar, depositando-a diretamente nos caminhões, as novas máquinas dispensam a utilização das máquinas carregadeiras, gerando o desemprego também dos operadores, do cortador e do catador, bem como do 'bituqueiro' (Scopinho e Valarelli, 1995; Scopinho et al.,1999). A introdução da colheita mecânica começou pelas usinas de maior porte, pois há necessidade de 
modificações técnicas, desde o plantio até o recebimento da cana-de-açúcar na usina. Essas modificações pressupõem investimentos elevados no redimensionamento dos talhões, no espaçamento entre as ruas, no nivelamento e na correção de falhas do terreno para possibilitar a produtividade máxima em toneladas de cana-de-açúcar por hora. Portanto, a substituição só é feita para aumentar o lucro do produtor, que só é positivo a partir de um tamanho mínimo de propriedade ou uma escala de produção suficiente para cobrir os custos fixos da adaptação. A preocupação ambiental só existe quando existe Legislação de controle, o que tem sido sempre postergado.

Entretanto, tem que se considerar que o trabalho da colheita manual da cana-de-açúcar é, certamente, uma das atividades laborais mais árduas do meio rural (Gonçalves, 2005). Além da postura física exigida para o corte, com o uso do 'podão'22, e da realização de atividades repetitivas e desgastantes, ele é praticado ao ar livre, com exposição ao sol e à chuva (Facioli, 2009). O pagamento do trabalho por produtividade diária é calculado em metros de cana-de-açúcar colhida e, depois, convertido em toneladas (Silva, 2008). Tal sistema estimula o trabalhador a forçar ao máximo seu desempenho produtivo na colheita. Isso gera pressão por resultados no ambiente de trabalho. Atualmente, a maior parte dos trabalhadores temporários da cana-de-açúcar provém das áreas mais pobres do país: do Nordeste, sobretudo Maranhão e Piauí, e do Vale do Jequitinhonha, em Minas Gerais (Ficarelli e Ribeiro, 2010). Os migrantes são, na maioria, jovens que se deslocam todos os anos, a partir 
do mês de março, e permanecem em alojamentos construídos pelas usinas ou em pensões das cidades-dormitório até o início do mês de dezembro. São os chamados 'migrantes temporários', embora essa migração seja permanentemente temporária (Roseiro, 2002).

Atualmente, a mecanização total da colheita é uma realidade, bem como a perda de postos de trabalho de baixa qualificação. Segundo dados da Pesquisa Nacional de Amostra de Domicílio (PNAD) do IBGE, observou-se uma redução de $23 \%$ dos empregados do setor de cana-deaçúcar entre 1992 e 2005 (Moraes, 2007). Em 1992, eram no país 670.099 empregados e, em 2005, os dados indicavam uma diminuição para 519.197. Apesar disso, os canaviais ainda constituem importante fonte de empregos para uma fração da população com baixo nível de instrução, e a cultura da cana-de-açúcar, em números absolutos, ainda é a atividade agropecuária que mais demanda mão de obra na colheita.

No Estado de São Paulo, segundo dados do Instituto de Economia Agrícola (IEA), foram estimados aproximadamente 163 mil trabalhadores empregados na safra 2006/07, com mais de $90 \%$ formalizados. Após denúncias de morte de trabalhadores por exaustão entre os anos de 2004 e 2008, feitas pela Pastoral do Migrante em Guariba - SP (Silva, 2008), e reportagens publicadas em jornais, como: Cortadores de cana têm vida útil de escravo em SP (Zafalon, 2007), contendo informações sobre essa situação degradante, o Governo Federal se mobilizou, visando a garantir condições de trabalho adequadas e saudáveis aos trabalhadores da cana-de-açúcar. Sob o comando da Casa Civil da Presidência da República, foi negociado um acordo entre empresários, trabalhadores e 
governo: o Compromisso Nacional para Aperfeiçoar as Condições de Trabalho na Cana-de-açúcar (Brasil, SGPR, 2009), assinado em 2009. Atualmente, o Ministério da Saúde exerce ações de fiscalização, por meio dos Centros de Referência em Saúde do Trabalhador (Cerest), oferecendo principalmente suporte técnico especializado em parceria com as Vigilâncias Municipais e Estaduais, considerando os seguintes aspectos: a responsabilidade sanitária sobre os riscos e agravos à saúde do trabalhador do setor canavieiro; a quantidade de trabalhadores expostos a riscos decorrentes desses ambientes laborais (aproximadamente 450 mil trabalhadores em 175 usinas de 130 municípios paulistas), e da população exposta aos riscos ambientais decorrentes das atividades do setor (Sanchez et al., 2009).

O aumento da produtividade das máquinas de colheita tornou a mecanização total da colheita de cana-de-açúcar um processo irreversível. Além de uma opção ambientalmente correta, ela passou a ser economicamente interessante. Para reduzir, pelo menos em parte, o problema gerado pela eliminação de postos de trabalho e o desemprego para essa categoria de trabalhador foi criado um programa de requalificação de trabalhadores chamado Programa Renovação, que deve atingir sete mil trabalhadores treinados por ano, entre funcionários e exfuncionários da cana-de-açúcar. Esse programa foi criado pela Unica e pela Federação dos Empregados Rurais Assalariado do Estado de São Paulo (Feraesp), com apoio do Banco Mundial (BM).

Considerando o exposto, minha posição é a favor da eliminação total da queima prévia da palha de cana-de-açúcar, da colheita manual e, 
consequentemente, do cortador. Essa posição corresponde à de Francisco Alves (2009, p.156-157), segundo a qual:

[...] não cabe à sociedade a defesa e a preservação de maus empregos. Devemos nos mobilizar pela criação de novos e bons empregos, que promovam a melhoria das condições de trabalho e o respeito aos direitos humanos, e preservem o meio ambiente. $O$ trabalho no corte de cana é uma atividade penosa, que aleija e mata trabalhadores.

\subsection{Vantagens da produção de etanol combustível a partir da cana-de-açúcar}

Após ser colhida, a cana-de-açúcar é transportada para a usina, onde é moída para extração do caldo de cana-de-açúcar. Durante o processo de extração do caldo, é gerado o bagaço como subproduto. Este é usado como combustível para alimentar as caldeiras da usina, sendo o seu excedente vendido como bioeletricidade (Castro et al., 2010). A energia da cana-de-açúcar é aproveitada de três formas: térmica, usada para o aquecimento de caldeiras no processo produtivo do açúcar e do etanol; mecânica, que movimenta as máquinas de extração e de preparação do caldo e turbinas de geração de energia; e elétrica, usada para o consumo próprio da usina ou vendida para as redes de distribuição do sistema elétrico. Segundo Zilmar de Souza (consultor para bioeletricidade da Única), "O setor sucroenergético tem um potencial ainda não explorado, em bagaço e palha, semelhante à quantidade de energia elétrica gerada por três usinas do porte de Belo Monte" (Única, Ethanol Summit 2011, p.25). 
Atualmente, o uso da biomassa da cana-de-açúcar (bagaço e palha) pode ser a melhor opção energética para o país, por diversos motivos. Dentre eles, podem ser citados a necessidade de atenuar os efeitos do aquecimento global, a contenção do aumento dramático dos preços da energia e o aumento da segurança energética por meio da redução da dependência das regiões produtoras de petróleo, em constante conflito. Isso, ainda que o Brasil seja autossuficiente em petróleo, pois o preço das commodities mundiais está atrelado ao preço do seu transporte, ainda muito dependente do uso de petróleo como combustível (Castro et al., 2010).

A bioeletricidade representa uma fonte de energia renovável, tecnicamente viável para substituição dos combustíveis fósseis na matriz energética do país.

O aumento das preocupações com as mudanças climáticas, provocadas pela emissão antrópica de gases causadores do efeito estufa (GEE), como o gás carbônico $\left(\mathrm{CO}_{2}\right)$ emitido pela queima dos combustíveis fósseis, levou o mercado internacional de energia a ampliar o interesse por combustíveis renováveis, como o etanol, mas foi exigido que a produção respeitasse padrões internacionais de conformidade socioambiental. Foi criado em 2009 um Comitê Internacional com participação de mais de 30 países, estando na coordenação o Brasil e a Alemanha, visando ao estabelecimento de uma norma internacional específica para Bioenergia, a (Sustainability Criteria for Bioenergy). Desse momento em diante, o setor sucroenergético organizado passou a participar de Fóruns nacionais e internacionais que tratam de questões de 
sustentabilidade ambiental, como a 15 Conferência das Partes (COP 15) da Convenção Quadro das Nações Unidas sobre Mudança do Clima (UNFCC), em Copenhague, Dinamarca, em 2009, quando a Única fez uma contundente defesa do etanol de cana-de-açúcar como alternativa concreta e disponível atualmente para o combate às mudanças climáticas $^{23}$. No mesmo evento, Ângela Merkel (Chanceler da Alemanha), enfatizou a necessidade de a energia da biomassa ser produzida de forma sustentável para a proteção climática, mas reforçou a necessidade de garantir que não haja conflito de interesses entre o desenvolvimento e a sustentabilidade.

O Instituto Nacional de Metrologia, Normalização e Qualidade Industrial (Inmetro) criou o Programa Brasileiro de Certificação em Biocombustíveis (WWF, 2008; Galdos, 2010) que atesta se o etanol brasileiro atende aos requisitos de sustentabilidade (social, ambiental e econômica) acordados internacionalmente, e se reduz a emissão dos gases do efeito estufa (GEE) e contribui para a mitigação das mudanças climáticas. Em linhas gerais, para o etanol de cana-de-açúcar receber certificação são exigidos: não utilizar trabalho escravo, nem infantil; não causar desmatamento; respeitar os direitos do trabalhador, e proporcionar condições adequadas de trabalho. Dessa forma, o etanol ganhará credibilidade, provando que colabora para a produção de energia mais sustentável. O produto brasileiro certificado se tornará mais competitivo em

23. UNICA defende na COP-15 a eficiência do etanol de cana no combate às mudanças climáticas. Notícias Internacionais, 9 dez 2009. Disponível em: http://www.unica.com.br/noticia/32751495920334743692/unica-defende-na-cop-15eficiencia-do-etanol-de-cana-no-combate-as-mudancas-climaticas/ 
relação às outras fontes de biocombustíveis e poderá ser comercializado livremente em todos os mercados como uma commodity mundial.

\subsection{Cultura de cana-de-açúcar no Estado de São Paulo}

O governo de São Paulo criou o Projeto Etanol Verde ${ }^{24}$, sob a coordenação da Secretaria do Meio Ambiente do Estado de São Paulo (SMA), devido à crescente expansão da atividade canavieira e sua importância na economia do estado, bem como à necessidade de organizar a atividade agrícola e industrial de modo a promover adequação ambiental e minimizar os impactos sobre o meio ambiente e a sociedade. O Etanol Verde articula 21 projetos estratégicos que estimulam a sustentabilidade da cadeia produtiva de açúcar, etanol e bioenergia, sendo um deles o Protocolo Agroambiental que determina medidas complementares para produtores e indústrias cumprirem, como o estabelecimento, por parte dos produtores, de um Plano Técnico de Conservação do Solo e de Recursos Hídricos ${ }^{25}$, a proibição gradual da queima prévia de palha de cana-de-açúcar em áreas de expansão do cultivo; a proibição da queima a céu aberto de quaisquer subprodutos da cana-de-açúcar; a proteção dos remanescentes florestais de nascentes e de matas ciliares; o adequado gerenciamento das embalagens de agrotóxicos, e a redução de consumo de água na etapa industrial. Essas iniciativas incorporam outros benefícios ambientais, como a possibilidade

${ }^{24}$ Disponível em: http://www.ambiente.sp.gov.br/etanolverde/index. php.

${ }^{25}$ Disponível em: http://www.ambiente.sp.gov.br/etanolverde/protocoloagroambiental/diretivas/. 
de aproveitamento da palha não queimada e do bagaço para cogeração de energia, propiciando às usinas autossuficiência energética e aumento de receitas com a venda do excedente em bioeletricidade. Todavia, esse caminho ainda não foi totalmente explorado, em virtude da necessidade de readequação das antigas usinas e do redimensionamento dos talhões da cultura da cana-de-açúcar.

\subsubsection{Monitoramento da área plantada e do tipo de colheita de cana-de-açúcar: com queima $(\mathrm{BH})$ ou sem queima $(\mathrm{GH})$}

A cana-de-açúcar é uma cultura agrícola semiperene, plantada em um ano e colhida em outro. Portanto, quando se faz referência à cultura de cana-de-açúcar, é usual referir-se à safra de dois anos - o ano em que ocorre o plantio e o ano seguinte da colheita. Após o plantio, o produto começa a ser colhido, a partir do mês de abril, estendendo-se até dezembro. A colheita da mesma planta se repete por vários anos - cinco no mínimo -, enquanto seu rendimento for razoável. Logo, no mesmo

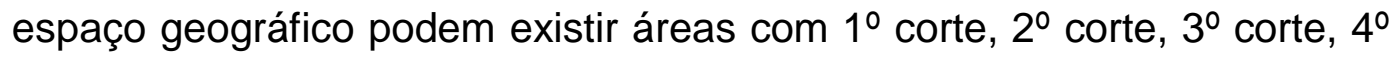
corte e $5^{\circ}$ corte (alguns casos podendo atingir até 10 cortes).

Os dados relativos à produção e à porcentagem de mecanização da cana-de-açúcar são conhecidos por meio dos dados fornecidos pelo Projeto Canasat-Inpe.

A identificação dos tipos de colheita, com ou sem queima, é um problema bem resolvido pela equipe do INPE, conforme Rudorff et al. (2010). O Canasat, por meio de sensoriamento remoto, avalia se os 
produtores do Estado de São Paulo estão substituindo a colheita manual da cana-de-açúcar pela colheita mecânica e sem queima, verde ${ }^{26}-$ e, consequentemente, eliminando o uso do fogo. Ao contrário da maioria das culturas, a cana-de-açúcar tem um extenso calendário de colheita. Portanto, seu monitoramento obriga a aquisição de imagens de todo o período de colheita. As imagens de sensoriamento remoto são obtidas pelo satélite Landsat-5, com o sensor TM (Thematic Mapper) a bordo, recobrindo sistematicamente o território brasileiro a cada 16 dias. Portanto, no período seco (entre os meses de abril e setembro), a probabilidade de se adquirir imagens livres de cobertura de nuvens no Estado de São Paulo é maior. Esse período também corresponde ao de maior intensidade de colheita da cana-de-açúcar no estado.

O trabalho de identificação do tipo de colheita em imagens de sensoriamento remoto é feito com base nas diferenças visuais da canade-açúcar colhida, com e sem queima prévia. Áreas onde a colheita foi processada com queima prévia da palha apresentam cores escuras nas imagens, por causa da mistura entre as cinzas do fogo e do solo. Já as áreas em que a colheita foi processada sem a queima da palha, aparecem brilhantes nas imagens, graças à presença dos resíduos da colheita, compostos principalmente de folhas secas.

Conforme informado pela equipe do Canasat, a interpretação visual das imagens é feita em dois passos:

\footnotetext{
${ }^{26}$ Colheita verde significa colheita sem queima.
} 
I. Primeiro, as imagens são avaliadas em ordem cronológica por diversos intérpretes, que identificam os campos da cultura e as classificam de acordo com tipo de colheita, com ou sem queima, e

II. A classificação final é revista por um único intérprete, para assegurar uniformidade na interpretação das imagens.

\subsubsection{Legislação de eliminação da queima e Protocolo Agroambiental}

A fiscalização do cumprimento do Protocolo Agroambiental é exercida por uma comissão tripartite composta por representantes das Secretarias de Estado do Meio Ambiente, Agricultura e dos produtores de cana-de-açúcar. As usinas aprovadas recebem um certificado de conformidade, o qual deve ser renovado anualmente e poderá ser cancelado em caso da mesma apresentar inconformidades. Além dos usineiros representados pela Única, também são signatários do acordo os fornecedores de cana-de-açúcar, representados pela Orplana. O estágio de cumprimento do Protocolo também pode ser acompanhado no site do Programa Etanol Verde $^{27}$ da SMA. Em 2012, 169 unidades haviam assinado o Protocolo, correspondendo a mais de $90 \%$ do parque agroindustrial paulista. Mais de 5.600 fornecedores, por meio de 27 associações no estado, também aderiram. Eles representam 94\% da produção de álcool do Estado de São Paulo e 56\% da produção do Brasil.

${ }^{27}$ Disponível em: http://www.ambiente.sp.gov.br/etanolverde. 
Esses dados estão disponíveis no site do Projeto Canasat-INPE em mapas e tabelas. (Anexo3).

A colheita de cana-de-açúcar sem queima passou de $34,2 \%$, em relação à área total, na safra agrícola 2006/07 para 55,5\% na safra 2009/10, o que significou um aumento de 1,3 milhões de hectares (ha) colhidos mecanicamente, sem utilização de fogo. A crise financeira mundial de 2008, que reduziu os investimentos no setor, acrescidos os efeitos da seca de 2009/10, foi acompanhada de ampliação em vez de redução da área queimada, tendo como consequência mudanças na previsão do final da queima prévia pela equipe do Projeto Canasat.

O processo de eliminação da prática da queima prévia de palha de cana-de-açúcar tem sido marcado por avanços e retrocessos, mas, de qualquer modo, trouxe benefícios à sociedade como:

- Melhoria do ar nas grandes cidades, com a substituição da gasolina pelo álcool como combustível veicular, pois evita emissão de toneladas de material particulado (MP), de monóxido de carbono (CO), e de hidrocarbonetos.

- No meio rural, onde a cana-de-açúcar é plantada, o cumprimento de diversas exigências ambientais pelos produtores que assinaram o Protocolo tem contribuído para evitar processos erosivos e assoreamento dos corpos d'água, devido à permanência da palha da cana-de-açúcar colhida crua nos canaviais.

- Diminuição do consumo de água pela indústria sucroenergética. Com a eliminação da queima prévia, torna-se desnecessária a lavagem da canade-açúcar na usina, o que reduz o consumo de água no processo de 
produção, tanto do etanol como do açúcar. Segundo o estudo da Embrapa Monitoramento por Satélite: Impacto ambiental da cana-deaçúcar (Embrapa, 2010) este passou de um consumo médio de $5 \mathrm{~m}^{3}$ de água por tonelada de cana-de-açúcar processada na década de 1990, para cerca de $1 \mathrm{~m}^{3}$ e meio por tonelada de cana-de-açúcar atualmente.

\subsection{Controlando outros impactos ambientais da cana-de- açúcar}

Atualmente, o Estado de São Paulo determina que a implantação ou ampliação de empreendimentos sucroalcooleiros se submeta ao licenciamento ambiental com base na Resolução SMA $n^{\circ} 88$, de

dezembro de 2008, para garantir condições sustentáveis para o desenvolvimento do setor. Por meio da Resolução, são definidos parâmetros e diretrizes para o licenciamento ambiental de empreendimentos sucroalcooleiros no estado. Com base no mapa do Zoneamento Agroambiental do Setor Sucroenergético no Estado de São Paulo (Anexo 2) são estabelecidas quatro classes de áreas, com diferentes graus de aptidão agroambiental e parâmetros específicos, de acordo com cada área, para a obtenção de licenças para operação dos empreendimentos. Essas medidas de controle visam à mitigação de outros danos causados pelas queimadas, como os descritos a seguir:

1) Eliminação dos predadores naturais de algumas pragas, como as vespas, inimigas da broca da cana-de-açúcar (Diatrea saccharalis), principal praga da região de Ribeirão Preto. Sem esses predadores, há 
descontrole dessa praga, exigindo a utilização cada vez maior de agrotóxicos, e causando, por sua vez, maior contaminação ambiental.

2) O fogo não mata as sementes das gramíneas invasoras. Ao contrário, estas, por não estar cobertas pela palha, germinam rapidamente. Para combater as plantas invasoras, os agricultores necessitam utilizar herbicidas em grande escala e em quantidade cada vez maior.

3) A eliminação da cobertura vegetal do solo favorece o escorrimento superficial da água das chuvas, agravando processos erosivos. Esse fenômeno é explicado pela insuficiência de cobertura do solo superficial, o qual, com a perda do húmus e a forte compactação pelas chuvas, torna-se impermeável, o que dificulta a infiltração da água e a brotação da vegetação.

Além desses inconvenientes, a queima dos canaviais apresenta outros, (Ometto et al., 2005) como o descontrole do fogo e os danos às redes elétricas. O fogo provoca a exsudação dos colmos e a perda de sacarose da cana-de-açúcar, além do desperdício de massa vegetal que poderia ser incorporada ao solo, e da destruição da fauna e da flora de organismos microscópicos do solo. Isso, sem levar em conta o carvãozinho preto que suja quintais e roupas colocadas nos varais, com o qual os moradores das cidades canavieiras são obrigados a conviver cada vez por período mais longo, devido à ampliação do período de colheita $^{28}$.

${ }^{28}$ Depoimento da autora, que morou em Piracicaba-SP por sete anos. 


\section{JUSTIFICATIVA}




\section{JUSTIFICATIVA}

A expansão da cultura da cana-de-açúcar no Brasil e, principalmente, no Estado de São Paulo é uma realidade (Martinelli, 2008). A queima prévia controlada da palha da cana-de-açúcar ainda é considerada uma prática agrícola imprescindível e necessária para a viabilização econômica da colheita. Atualmente, em mais de $70 \%$ dos municípios do Estado de São Paulo, a população é obrigada a conviver com a queima prévia da palha de cana-de-açúcar, sendo esse um possível fator de risco à saúde da população do interior, que aumenta a sua vulnerabilidade às doenças crônicas não transmissíveis em geral, principalmente as doenças respiratórias. O aumento nos números de internação hospitalar e de mortalidade devido a essa causa provoca acréscimo nos gastos públicos em saúde. Desse modo, entende-se que a questão da queima prévia deve ser vista não somente como um problema ambiental e de saúde pública, mas também como um problema econômico relacionado à boa gestão de recursos públicos. Isso porque a maior parte dos gastos com a saúde da população é arcada pelo Sistema Único de Saúde (SUS), e o benefício (do incremento da produtividade e consequente aumento da margem de lucro da atividade econômica) é recebido apenas pelos envolvidos na cadeia produtiva do setor sucroenergético.

Desde 2007, existe, no Estado de São Paulo, o Protocolo Agroambiental para eliminação da queima prévia de palha de cana-de- 
açúcar, com adesão crescente de usinas e fornecedores de cana-deaçúcar. A SMA informa que mais de 94\% do total de cana-de-açúcar produzida já obedece às diretivas estabelecidas pelo Protocolo. Entretanto, sabe-se que a queima da palha de cana-de-açúcar e a consequente emissão de poluentes ainda vão impactar a saúde das regiões canavieiras do estado até, pelo menos, 2017. Isto, se não ocorrer o previsto atraso na implantação do Protocolo. Segundo estudo de Aguiar (2011), esses prazos devem ser postergados para 2015 ou 2016.

Esse Protocolo foi assinado tanto pelos usineiros como pelos plantadores e fornecedores de cana, mas é apenas um acordo e não uma Lei. Além disso, é importante ressaltar que, mesmo nos estados onde já foi assinado um protocolo de eliminação da queima prévia, este será um processo gradual. Portanto, são necessárias atitudes preventivas concretas para diminuir os danos à saúde devidos à queima direcionados à população das cidades canavieiras.

Conforme Ezzati e Riboli (2012), estudos de base individual são importantes para avaliar o risco de doenças, mas para saber a efetividade das ações de prevenção é necessário realizar estudos com base em dados de população. Desse modo, no âmbito da saúde pública, estudos de modelagem, como o proposto neste sobre o impacto da queima podem ser uma contribuição para o estabelecimento de medidas de vigilância epidemiológica. Medidas essas necessárias à redução de danos à saúde devidos à prática de queima prévia da palha de cana-de-açúcar, até sua eliminação total. 

OBJETIVOS 


\section{OBJETIVOS}

O objetivo deste trabalho foi examinar a associação entre a queima prévia da palha de cana-de-açúcar e a ocorrência de doenças respiratórias nos municípios do Estado de São Paulo, levando em consideração também covariáveis climáticas e socioeconômicas em nível municipal. Esta avaliação foi feita nos meses de abril a outubro de 2010. 
HIPÓTESE 


\section{HIPÓTESE}

Considero que a prática agrícola de queima prévia da palha de cana-de-açúcar tem um impacto negativo na saúde da população do Estado de São Paulo. 


\section{MÉTODOS}




\section{MÉTODOS}

\subsection{Desenho do estudo}

Este é um estudo epidemiológico ecológico (Rothman, 2013), que usa modelo de regressão espacial Bayesiano. Relaciono indicadores de exposição à queima da palha de cana-de-açúcar aos efeitos na saúde. Estes foram medidos por meio da Razão de Mortalidade (RMtP) e Morbidade Padronizadas (RMbP) por doenças respiratórias, nas faixas etárias acima de 65 anos e internações por doença respiratória, nas faixas etárias menores de 5 anos e acima de 65 anos em cada um dos municípios do Estado de São Paulo.

\section{2 Área e período de estudo}

O objeto desta investigação foi o Estado de São Paulo e a unidade de análise seus 645 municípios. O efeito da queima prévia foi medido apenas nos municípios aonde ocorre produção de cana-de-açúcar em escala comercial. A produção de cana monitorada segundo o tipo de colheita (com ou sem queima) no ano de 2010, Para retirar "ruído" da análise, considerei apenas o período de maior ocorrência de queima de palha de cana-de-açúcar no Estado de São Paulo, os meses de abril a 
outubro $^{29} \cdot$. Os dados socioeconômicos usados são considerados apenas em um mês específico de 2010.

\subsection{Variáveis utilizadas e fontes de dados}

\subsubsection{Desfechos: variáveis dependentes}

As variáveis dependentes escolhidas foram Mortalidade e a Morbidade por doenças respiratórias (Capítulo $X$ da $10^{\mathrm{a}}$ Revisão da Classificação Internacional de Doenças - CID 10). Extraí os dados para os desfechos do Departamento de Informática do SUS (DATASUS) ${ }^{30}$ do Ministério da Saúde. Optei por utilizar dados completos sobre as doenças do aparelho respiratório (letra $\mathrm{J}$ de $00-100$ ), devido à preocupação com a confiabilidade dos diagnósticos de bancos de dados hospitalares.

\subsubsection{Mortalidade por doenças respiratórias}

Extraí os dados de mortalidade por local de residência para idosos com idade igual ou superior à 65 anos do Sistema de Informações sobre Mortalidade $(\mathrm{SIM})^{31}$ da Secretaria de Vigilância em Saúde processada pelo DATASUS-MS , para os 645 municípios do Estado de São Paulo, nos meses de abril a outubro de 2010. Em vista do pequeno número de óbitos observados, que causaria grande variabilidade nas taxas de 29 Justificativa da escolha explicada pela análise do número mensal de focos de queima (Anexo 5).

${ }^{30}$ Disponível em: http://www.datasus.gov.br.

${ }^{31}$ Disponível em: http://www.datasus.gov.br/tabnet/sim. 
mortalidade preferi não analisar a mortalidade por doenças respiratórias em crianças menores de 5 anos de idade.

\subsubsection{Morbidade hospitalar por doenças respiratórias}

Extraí os dados de morbidade por doenças respiratórias das Autorizações de Internação Hospitalar $(\mathrm{AlH})^{32}$ por local de residência, oriundas do Sistema de Informações Hospitalares (SIH/SUS) da Secretaria de Assistência à Saúde $(S A S)^{33}$, que tem origem de informações fornecidas conjuntamente pelas Secretarias Estaduais e Municipais de Saúde e são processadas pelo DATASUS-MS. A abrangência do sistema está limitada às internações no âmbito do SUS, excluindo-se as custeadas diretamente ou cobertas por seguro-saúde. Estima-se que o SIH/SUS reúna informações sobre $60 \%$ a $70 \%$ das internações hospitalares realizadas no país, variando de acordo com a região. Eventuais reinternações e transferências do mesmo paciente para outros hospitais também não são identificadas, o que poderia resultar em contagem cumulativa e superestimação dos dados. As faixas etárias examinadas incluíram crianças com idade inferior a 5 anos e idosos com idade igual ou superior a 65 anos, para os 645 municípios do Estado de São Paulo, nos meses de abril a outubro de 2010.

${ }^{32}$ Disponível em: http://tabnet.datasus.gov.br/cgi/sih/.

${ }^{33}$ Disponível em: http://www.saude.gov.br/sas. 


\subsubsection{Medidas de Exposição: variáveis independentes}

O Estado de São Paulo se localiza entre os paralelos 1950', $24^{\circ} 30^{\prime} \mathrm{S}$ e os meridianos $44^{\circ} 00^{\prime}$ e $53^{\circ} 30^{\prime} \mathrm{W}$, na região Sudeste do Brasil, e ocupa área de $248.209,4 \mathrm{~km}^{2}$. Em 2010, a área total de produção de cana-de-açúcar foi de 4.728.135 hectares (ha), sendo que 2.627.025ha $(55,6 \%)$ foram colhidos verdes $(\mathrm{GH})$ e 2.101 .110 ha $44 \%$ colhidos com queima $(\mathrm{BH})$ (Figura 6).

Considerei como população exposta à queima da palha de canade-açúcar toda a população dos municípios paulistas, onde, em 2010, ocorreu colheita de cana-de-açúcar com queima prévia. A impossibilidade de medir diretamente a exposição levou ao uso das medidas indiretas: Focos de Queima (Focos), Percentual de Queima Municipal (PQM) e Profundidade Óptica dos Aerossóis (Aerossol), descritas a seguir.

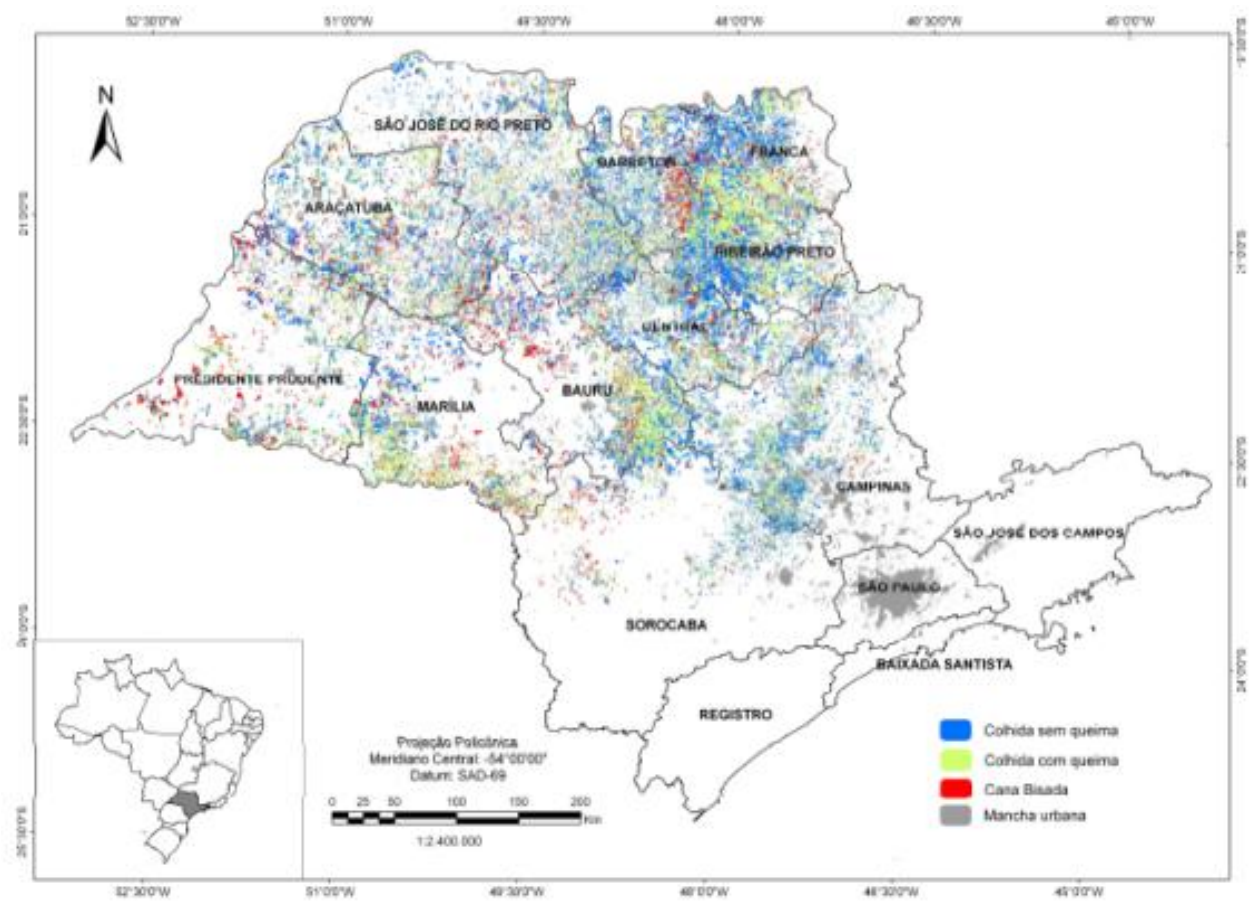

Figura 6 - Modos de colheita de cana no Estado de São Paulo, 2010. 


\subsubsection{Focos de Queima}

Um foco indica a existência de fogo na vegetação em um elemento de resolução da imagem (pixel), que varia de $1 \mathrm{~km} \times 1 \mathrm{~km}$, até $5 \mathrm{~km} \times 4 \mathrm{~km}$, dependendo do satélite e de sua posição em relação ao foco de queima. Embora em um pixel possa existir uma ou várias queimadas distintas, a indicação será de um único foco. Além disso, se uma queimada for muito extensa, ela será detectada em mais de um pixel vizinho ou próximo, ou seja, vários focos estarão associados a uma única grande queimada. Apesar das limitações descritas, usei as medidas de Focos de Queima (Focos), por município como uma das variáveis independentes na modelagem.

A quantidade acumulada de focos de queima representa a melhor estimativa possível da quantidade de fontes de emissão de fumaça obtida de forma metódica e regular para o território brasileiro. Para este estudo, usei a quantidade diária em cada município obtida a partir de consulta ao banco de dados de queimadas do INPE $^{34}$, o qual mostra a quantidade de focos contidos nos limites políticos de cada município paulista. Esses dados são obtidos pela leitura de todos os satélites que possuem sensores ópticos (cada tipo de sensor tem seu próprio algoritmo) recebidos pelo INPE, o qual processa mais de cem imagens por dia, especificamente para detectar focos de queima da vegetação.

\footnotetext{
${ }^{34}$ Disponível em: http://sigma.cptec.inpe.br/queimadas, acessado em novembro de 2012.
} 
Extraí dados mensais do número de Focos de Queima dos 645 municípios paulistas em estudo, para os anos de 2006 a 2010 (Anexo 5). Verifiquei que os focos de queima no Estado de São Paulo se concentram nos meses de abril a outubro. A partir dessa constatação, passei a usar somente esses meses para me referir aos eventos de queima de cana no ano de 2010, para diminuir o "ruído" nos dados com uso dos meses nos quais não ocorre colheita de cana com queima.

\subsubsection{Porcentagem da área de cana-de-açúcar colhida com queima prévia de palha (PQM)}

Obtive os dados do tipo de colheita de cana-de-açúcar em 482 municípios paulistas diretamente do site do Projeto Canasat ${ }^{35}$. Essa área (em hectares) de colheita de cana-de-açúcar realizada com queima prévia (nos meses de abril a outubro) de 2010 foi dividida pela área oficial do município (Resolução nº 05 de outubro de 2002, IBGE) e multiplicada por 100, para obter o Percentual de Queima Municipal (PQM).

\subsubsection{Profundidade Óptica dos Aerossóis (Aerossol)}

O Ministério da Saúde, por meio de sua Coordenação Geral de Vigilância em Saúde Ambiental (CGVAM/DSAST/SVS/MS), em cooperação técnica científica com a Fundação Oswaldo Cruz (FIOCRUZ) desenvolveu o Sistema de Informações Ambientais Integrado à Saúde

\footnotetext{
${ }^{35}$ Disponível em: http://www.dsr.inpe.br/laf/canasat/index.html.
} 
Ambiental-SISAM ${ }^{36}$ (Anexo 4) em parceria com o INPE. Retirei do SISAM as variáveis climáticas e a variável de exposição Profundidade Óptica dos Aerossóis (Aerossol).

Os aerossóis são partículas sólidas ou líquidas suspensas na atmosfera com tamanho da ordem de dezenas de nanômetros a centenas de micrômetros, podendo ter origem em processos naturais, como erupção de vulcões, tempestades de areia etc., ou ser produzidos por atividades humanas, como a queima da palha de cana-de-açúcar ou outra vegetação, e ressuspensão de solo ou queima de combustíveis fósseis. A Profundidade Óptica dos Aerossóis (Aerossol) indica a capacidade de o aerossol interagir com a radiação solar incidente. Essa interação consiste em o aerossol absorver e/ou dispersar a radiação incidente, e depende do tipo e concentração do aerossol. Partículas de aerossol podem influenciar o clima em escalas regionais e globais por meio de interações diretas, atuando como centros espalhadores ou absorvedores de luz solar. São valores adimensionais e descrevem a presença do aerossol em toda a coluna atmosférica, da superfície até aproximadamente $10 \mathrm{~km}$.

\subsubsection{Covariáveis}

\subsubsection{Variáveis socioeconômicas}

A definição de saúde como "um estado de completo bem-estar físico, mental e social e não meramente a ausência de doença ou

\footnotetext{
${ }^{36}$ Disponível em: http://sisam.cptec.inpe.br/sisam.
} 
enfermidade", inserida na constituição da Organização Mundial de Saúde em 1948 é uma concepção de saúde não centrada apenas na doença (Medronho et al., 2009). Esse conceito foi atualizado na década de 1990 com o debate sobre as Metas do Milênio ${ }^{37}$, ampliando mais essa visão, fortalecida pela criação, em 2005, da Comissão sobre os Determinantes Sociais em Saúde da OMS. Essas considerações demonstram a necessidade da inclusão de variáveis socioeconômicas na modelagem de processos de saúde-doença. Tomando por base o Programa de Metas do Milênio, que faz uso de indicadores de saneamento, educação e renda para caracterizar o nível de desenvolvimento da população, usei neste estudo informações de cada município paulista publicadas na Série Indicadores Sociais Municipais. Uma análise dos resultados do universo do Censo Demográfico (Brasil, MP, 2011). Usei os seguintes conceitos definidos pelo IBGE:

Saneamento adequado: é aquele com escoadouro ligado à rede geral ou à fossa séptica, servido de água proveniente de rede geral de abastecimento e com destino do lixo coletado diretamente ou indiretamente pelos serviços de limpeza. O IBGE criou um índice de adequabilidade do tipo de saneamento como maneira de dimensionar as condições de saneamento básico dos domicílios.

Renda: proporção de pessoas residentes em domicílios particulares com rendimento mensal total domiciliar per capita nominal de até $1 / 2$

${ }^{37}$ Disponível em: http://www.un.org/millenniumgoals. 
salário mínimo rendimento nominal mensal da pessoa de 10 anos ou mais de idade, a soma do rendimento nominal mensal de trabalho com o proveniente de outras fontes.

\section{Educação: taxa de analfabetismo da população maior ou igual a 15} anos. É considerada alfabetizada a pessoa capaz de ler e escrever um bilhete simples no idioma que conhece. É considerada analfabeta a pessoa que aprendeu a ler e escrever, mas se esqueceu como se faz, devido a ter passado por um processo de alfabetização que não se consolidou, e apenas assina o próprio nome.

\subsubsection{Variáveis climáticas}

No Estado de São Paulo, a cultura de cana-de-açúcar se concentra principalmente nas regiões centro-norte e oeste (Aguiar et al., 2009), onde predomina o clima tropical com as características principais de chuvas durante a estação do verão e seca durante o inverno. Na estação chuvosa, a temperatura média é de $22^{\circ} \mathrm{C}$, enquanto $18^{\circ} \mathrm{C}$ é a média da estação seca. Nas áreas serranas altas, como a Serra da Mantiqueira e a Serra do Mar, onde predomina o clima subtropical e temperaturas inferiores a $18^{\circ} \mathrm{C}$ no mês mais frio e um verão mais ameno, não existe plantio de cana-de-açúcar para indústria.

O clima é reconhecido por sua influência sobre a saúde, principalmente sobre a incidência de doenças respiratórias. Visando a 
controlar seu efeito, acrescentei ao modelo dados de temperatura, umidade e precipitação descritas a seguir:

a) Umidade Relativa do ar (UR): Usei esta variável, pois sua variação pode interferir no sistema respiratório e na sensação térmica. Ela representa a relação entre a pressão de vapor do ar local e a pressão obtida em condições de equilíbrio ou saturação sobre uma superfície de água líquida ou gelo. Por convenção, o valor de UR é denotado em porcentagem e varia de 0 a 100. Para determinada temperatura, quanto maior o valor de UR, maior é a quantidade de umidade presente na atmosfera. Por ser altamente dependente da temperatura (inversamente proporcional), essa variável tem ciclo diurno bem definido, atingindo seu mínimo próximo das $15 \mathrm{~h}$ e máximo próximo das $6 \mathrm{~h}$. Os valores de Umidade mensal (máxima, média e mínima) extraídos são resultado da estimativa feita pelo Modelo Atmosférico Regional CATT-BRAMS ${ }^{38}$ (Freitas et al., 2007) com $25 \mathrm{~km}^{2}$ de resolução espacial.

b) Temperatura (graus Celsius): Indica a quantidade de energia térmica da atmosfera, e está associada a noções de frio e calor. O excesso de calor aumenta o risco de problemas cardíacos, diarreia, dores de cabeça e problemas de pele. Ela é variável no tempo e no espaço, de acordo com a radiação solar incidente ao longo do ano, movimentação de massas de ar, aquecimento diferencial da terra e da água, correntes oceânicas, altitude, posição geográfica do local onde está sendo mensurada. Como

${ }^{38}$ Disponível em: www.cptec.inpe.br/brams. 
resultado do Modelo Atmosférico Regional CATT-BRAMS, obtive a estimativa da Temperatura mensal (máxima média e mínima) usada no estudo.

c) Precipitação acumulada $\left(\mathrm{mm} / \mathrm{m}^{2}\right)$ : É a quantidade de chuva acumulada ao longo do dia estimada pelo modelo. Os valores de precipitação acumulada são dados em milímetros de água sobre uma determinada área, sendo que um $\mathrm{mm}$ de água equivale a um litro por $\mathrm{m}^{2}$. A quantidade de chuva acumulada é baseada na taxa de precipitação instantânea estimada a partir de imagens do satélite GOES, utilizando-se uma relação entre a temperatura do topo da nuvem e a chuva na superfície. O método que calcula essa taxa é chamado de hidroestimador. As taxas são acumuladas das $12 \mathrm{~h}$ do dia anterior às $12 \mathrm{~h}$ do dia corrente. A estimativa de precipitação por satélite se tornou uma ferramenta de grande valor no monitoramento dessa variável para verificar a ocorrência e a quantidade de chuva, devido à baixa densidade de pluviômetros sobre o território brasileiro. Calculei o valor da Média Mensal de Precipitação Acumulada $\left(\mathrm{mm} / \mathrm{m}^{2}\right)$ e inseri na modelagem.

Atualmente dispomos do Portal do INPE-SISAM, que fornece dados climáticos diários e mensais, obtidos por sensoriamento remoto ou por modelagem matemática para todos os municípios brasileiros. Assim foi possível criar um Banco de Dados Climáticos só com dados dos municípios paulistas com cana-de-açúcar em 2010. 


\subsection{Análises}

No presente estudo ecológico, propus um Modelo de Regressão Múltipla para comparar os riscos de óbitos e internações por doença respiratória entre os municípios paulistas com diferentes padrões de exposição à queima de cana-de-açúcar, e usei as Razões de Mortalidade (RMtP) e Morbidade Padronizadas (RMbP) como variável resposta (Medronho et al., 2009). A padronização usou como taxa de referência o total de internações e óbitos para todos os municípios do Estado de São Paulo, no ano de 2010. Essa taxa, aplicada à população de cada município, gerou o número de internações e óbitos que seriam esperados (Ei). Os valores de internações e óbitos observados (Oi) (extraídos do DATASUS) foram, então, divididos pelos valores esperados (Ei), obtendose as (RMtP) e (RMbP) para doenças respiratórias nos 645 municípios paulistas, nas duas faixas etárias analisadas.

Essas Razões estimadas para determinados municípios podem apresentar grande instabilidade para expressar o risco de um evento, quando o mesmo é raro ou a população do referido município é pequena. Desse modo, flutuações dessas Razões podem não ter relação com algum fenômeno em estudo, mas sim com a ocorrência de um ou dois casos do evento - a mais ou a menos - em uma determinada localidade. (Brasil, Ministério da Saúde, 2007a). Consequentemente, um mapa produzido com esses dados brutos pode não representar o verdadeiro processo que se deseja demonstrar (Kato et al., 2009). Além disso, os 
valores de Razões Padronizadas para cada município não constituem estimativas independentes, ou seja, elas possuem dependência espacial (município com os demais vizinhos), também conhecida como autocorrelação espacial (Brasil, MS, 2007a).

Para lidar com a mencionada instabilidade nas estimativas de RMP e sua autocorrelação (Rothman, 2011), a partir de consulta a literatura, escolhi para análise o modelo Bayesiano hierárquico completo (Bernardinelli, 1992).

Como variáveis independentes, testei separadamente três medidas indiretas de exposição à queima de palha de cana-de-açúcar: a) Somatória do Total Mensal de Focos de Queima (Focos), b) Somatória da Média Mensal da Profundidade Óptica dos Aerossóis e c) Percentual (\%) de Queima por Município (PQM), para cada um dos 645 municípios paulistas.

O possível efeito de confusão, relacionado à influência do clima e das diferenças de condição socioeconômicas dos municípios paulistas sobre a ocorrência das doenças respiratórias, foi tratado com a inserção no modelo de variáveis explicativas referentes à condição climática local (temperatura, umidade e precipitação) e as variáveis explicativas referentes à condição socioeconômica dos municípios (saneamento, educação e renda), as quais também apresentam autocorrelação.

No modelo proposto, considerei que o número de casos de óbitos ou internações por doenças respiratórias observadas por município (Oi) segue uma função exponencial com Distribuição de Poisson. Aproveitando as vantagens matemáticas e computacionais que a 
transformação logarítmica proporciona, testei o modelo descrito pela equação abaixo:

$\operatorname{Ln}(O i) /(E i)=\quad \alpha_{i}+\beta_{1}$ Fator exp. $+\beta_{2}$ Precipitação

$+\beta_{3}$ Temperatura Máxima+ $\beta_{4}$ Umidade Mínima

$+\beta_{5}(\%)$ Saneamento $+\beta_{6}(\%)$ Analfabetismo $+\beta_{7}(\%)$ Renda (1/2SM).

$I=1,2, \ldots, 645$.

Em que:

$\mathbf{O} \boldsymbol{i}=$ número de casos de óbitos ou internações por doença respiratórias observados em indivíduos com menos de cinco anos ou mais de 65 anos no município i;

$\boldsymbol{E}_{t .}=$ número de eventos esperados no município i;

$\alpha_{i}=$ logaritmo natural do risco relativo do município i;

$\boldsymbol{\beta}_{\boldsymbol{k}}=$ Efeito dos parâmetros ajustados no município i;

Fator exp. = (PMQ, Aerossol, Focos $)$ medida indireta de exposição à queima.

Para a análise, utilizei o método de estimação de cadeias de Markov MCMC (Markov Chain-Monte Carlo) e calculei por meio do 'software' livre 'Winbugs' 1.4.0 (Win Bayesian inference Using Gibbs Sampling ${ }^{39}$, próprio para análise Bayesiana de modelos complexos. E visando 'suavizar' as estimativas da RMP para cada desfecho e município em cada modelagem, foram realizadas 10.000 interações, utilizando apenas uma cadeia de Markov, por método de estimação de Monte Carlo

\footnotetext{
${ }^{39}$ Disponível em: http://www.mrcbsu.cam.ac.uk/bugs/winbugs/contents.shtm.
} 
(MCMC). Assim, as RMP ajustadas refletiram melhor a dinâmica da morbidade e mortalidade por doenças respiratórias no Estado de São Paulo.

Também para promover o ajuste da autocorrelação entre os dados, criei uma matriz de vizinhança de primeira ordem, contendo os 645 municípios do Estado de São Paulo, com auxilio do software MAPINFO PROFESSIONAL - Versão 10.0. A matriz indica como cada município se relaciona espacialmente com os demais e seu valor foi usado no modelo Bayesiano descrito (Medronho et al., 2009).

Testei cada medida ou fator de exposição (PQM, Aerossol e Focos de queima) separadamente.

Relacionando cada um dos fatores de exposição com os desfechos estudados, pude testar nove diferentes modelos de regressão.

As $(\mathrm{RMtP})$ e $(\mathrm{RMbP}) \quad$ calculadas através da análise bayesiana, conhecidas como suavizadas, me permitiram a elaboração de mapas coropléticos (Brasil, MS, 2007a). Eles foram elaborados usando-se o Programa MAPINFO PROFESSIONAL - Versão 10.0, e permitem a visualização do grau de excesso de casos de risco para doenças respiratórias nos municípios paulistas, associados com a exposição. Neles através da saturação da cor, os municípios podem ser ordenados em classes distintas.

Em todas as análises foi adotado como nível de significância o $\alpha=$ $5 \%$.

Este estudo recebeu aprovação da Comissão de Ética para Análise de Projetos de Pesquisa do HCFMUSP, CAPPesq. Eu recebi bolsa de 
estudos da Coordenação de Aperfeiçoamento de Pessoal de nível Superior, CAPES durante o desenvolvimento do trabalho.

O conjunto dos resultados é apresentado a seguir. 
RESULTADOS 


\section{RESULTADOS}

O Estado de São Paulo é o maior produtor de cana-de-açúcar do Brasil. Ele responde por $54 \%$ da produção nacional e por $20 \%$ da produção mundial de etanol, segundo estimativa da Companhia Nacional de Abastecimento, Conab (Conab, 2011). Todos os municípios que têm produção de cana-de-açúcar para indústria utilizam a queima prévia como prática agrícola, isto é, tem queima.

Segundo Aguiar et al. (2007), existiam 3,2 milhões de hectares disponíveis para a colheita em 430 municípios na safra 2006/2007. A área foi expandida para 4,7 milhões de hectares em 2010 (Aguiar et al., 2011), ocupando 482 municípios. Portanto, verifica-se nesse período uma expansão de $11 \%$ no número de municípios com cana-de-açúcar no estado.

\subsection{Variações Climáticas, municípios paulistas com cana-de- açúcar, em 2010 (usados no modelo).}

Os dados climáticos, para os meses de abril a outubro, dos 478 municípios que foram usados no modelo estão descritos estatisticamente na Tabela 1 abaixo. Eles confirmam a pressuposição de que não existem grandes variações climáticas no Estado de São Paulo nos municípios onde existe o plantio de cana-de-açúcar para agroindústria. A temperatura nesse período teve uma variação de $14^{\circ} \mathrm{C}$ a $27^{\circ} \mathrm{C}$, e a umidade do ar apresentou variação de $48 \%$ a $93 \%$. Portanto praticamente não existe 
clima frio o que é razoável considerando que a colheita de cana-deaçúcar em São Paulo se concentra na estação seca, que vai de maio a setembro (São Paulo, CETESB, 2009). Portanto, o período estudado (abril a outubro) não incluiu os meses do ano com maior pluviosidade. Mesmo assim, em 2010 a precipitação apresentou 8\% de desvio padrão.

Tabela 1: Descrição das variáveis climáticas de municípios paulistas usadas no modelo.

Período: Abril-outubro - 2010

\begin{tabular}{|c|c|c|c|c|c|c|}
\hline Variável & UN. & Média & Fonte & D.P. & Mín. & Máx. \\
\hline $\begin{array}{c}\text { Temp. } \\
\text { Min. }\end{array}$ & ${ }^{\circ}$ Celsius & 16.62 & $\begin{array}{c}\text { CATT- } \\
\text { BRAMS }\end{array}$ & 1.03 & 14.02 & 18.68 \\
\hline $\begin{array}{c}\text { Temp. } \\
\text { Méd. }\end{array}$ & ${ }^{\circ}$ Celsius & 20.44 & $\begin{array}{c}\text { CATT- } \\
\text { BRAMS }\end{array}$ & 1.34 & 16.68 & 22.77 \\
\hline $\begin{array}{c}\text { Temp. } \\
\text { Max }\end{array}$ & ${ }^{\circ}$ Celsius & 24.48 & $\begin{array}{c}\text { CATT- } \\
\text { BRAMS }\end{array}$ & 1.44 & 20.07 & 27.18 \\
\hline $\begin{array}{c}\text { Um. Mín. } \\
\text { CRrecipit } \\
\text { med. }\end{array}$ & $\% m / m^{2}$ & 51,32 & Sat. GOES & 8,08 & 31,48 & 82,10 \\
\hline $\begin{array}{c}\text { Um. Méd. } \\
\text { Um. Máx. }\end{array}$ & $\%$ & 84.81 & Sat. GOES & 4.18 & 48.82 & 69.06 \\
\hline
\end{tabular}

Fonte: SISAM/INPE. 
$\mathrm{Na}$ Tabela 2, são apresentadas as análises de correlação (Pearson) entre os dados climáticos dos municípios e os desfechos analisados. Dada a inerente correlação entre as variáveis climáticas (média, máxima e mínima) e observando o padrão de correlação entre estas e o desfechos estudados, optei por selecionar a Umidade Mínima (\%) e a Temperatura Máxima (graus Celsius) para inclusão no modelo final. Essas duas variáveis, juntamente com a variável Média Mensal de Precipitação Acumulada $\left(\mathrm{mm} / \mathrm{m}^{2}\right)$ foram inseridas na modelagem Bayesiana.

Tabela 2 - Análise de Correlação das variáveis climáticas e RMP s municípios paulistas inseridos no modelo.

Período: Abril-outubro - 2010

\begin{tabular}{lcccc}
\hline Correlação & & $\begin{array}{c}\mathrm{RM} \mathrm{tP} \\
(>65 \text { anos })\end{array}$ & $\begin{array}{c}\mathrm{RM} \mathrm{bP} \\
(<5 \text { anos })\end{array}$ & $\begin{array}{c}\text { RM b P } \\
(>65 \text { anos })\end{array}$ \\
\hline \hline Temperatura & $\mathrm{r}$ & $-0,061$ & 0,133 & 0,198 \\
máxima* & $\mathrm{p}$ & 0,183 & $\mathbf{0 , 0 0 4}$ & $<0,001$ \\
Temperatura & $\mathrm{r}$ & $-0,062$ & 0,127 & 0,202 \\
média & $\mathrm{p}$ & 0,180 & $\mathbf{0 , 0 0 6}$ & $<0,001$ \\
Temperatura & $\mathrm{r}$ & $-0,056$ & 0,123 & 0,211 \\
mínima & $\mathrm{p}$ & 0,221 & $\mathbf{0 , 0 0 7}$ & $<0,001$ \\
Umidade & $\mathrm{r}$ & 0,032 & $-0,077$ & $-0,198$ \\
máxima & $\mathrm{p}$ & 0,485 & 0,095 & $<0,001$ \\
Umidade & $\mathrm{r}$ & 0,036 & $-0,085$ & $-0,186$ \\
média & $\mathrm{p}$ & 0,432 & 0,063 & $<\mathbf{0 , 0 0 1}$ \\
Umidade & $\mathrm{r}$ & 0,038 & $-0,098$ & $-0,169$ \\
mínima* & $\mathrm{p}$ & 0,406 & $\mathbf{0 , 0 3 3}$ & $<0,001$ \\
Precipitação & $\mathrm{r}$ & $-0,083$ & 0,034 & 0,133 \\
& $\mathrm{p}$ & 0,069 & 0,464 & $\mathbf{0 , 0 0 4}$
\end{tabular}

Fonte: SISAM/INPE.

7.2. Condições Socioeconômicas, municípios paulistas com cana-de-açúcar, em 2010 (usados no modelo). 
A riqueza trazida pela cana-de-açúcar não é realidade para toda população das cidades canavieiras. Como se pode constatar na Tabela 3 e no Gráfico 2, o saneamento básico adequado está presente em $80 \%$ das cidades canavieiras, mas pode se observar que existem cidades que tem apenas $20 \%$ de saneamento básico nos domicílios.

Tabela 3 - Descrição das variáveis socioeconômicas de municípios paulistas inseridos no modelo - 2010

\begin{tabular}{lrrrrrrr}
\hline Variável & Média & \multicolumn{1}{c}{ DP } & Mínimo & P25 & Mediana & P75 & Máximo \\
\hline \hline \% Saneamento & 84,04 & 11,53 & 24,54 & 79,29 & 86,49 & 92,12 & 98,85 \\
\% Renda até 1/2 & 22,41 & 7,04 & 7,62 & 17,09 & 21,98 & 26,47 & 50,55 \\
SM & & 2,46 & 2,67 & 5,93 & 7,63 & 9,28 & 15,30 \\
\% Analfabetismo & 7,76 & & & & & & \\
\hline
\end{tabular}

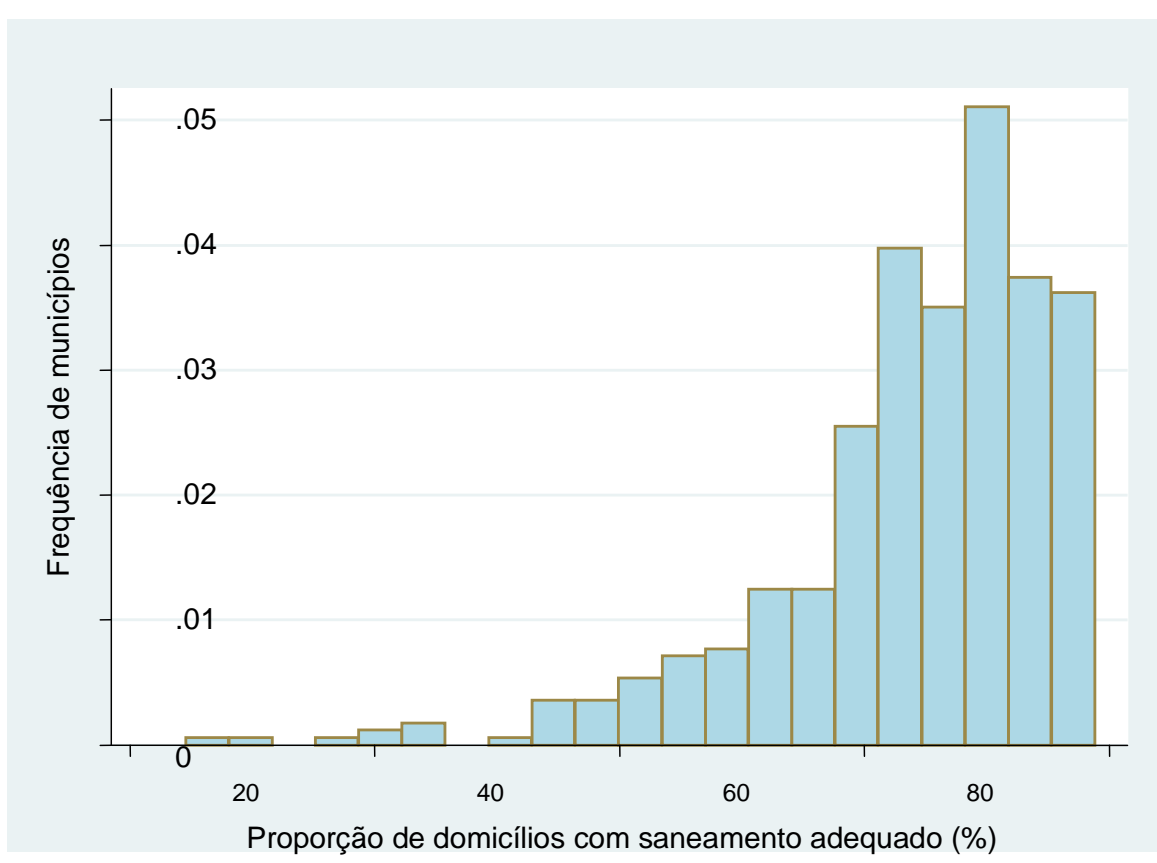

Gráfico 2 - Condições de Saneamento municípios paulistas - 2010: proporção de domicílios com saneamento básico adequado 
Também pela mesma Tabela 3 e observando o Gráfico 3, é possível observar que a proporção da população com renda até 1/2 salário mínimo apresenta muita variação, mas a situação prevalente são de municípios aonde $20 \%$ a $30 \%$ da população possui renda per capita média de até $1 / 2$ salário mínimo. $E$ ainda se observa situações bem precárias, por exemplo, municípios aonde até $50 \%$ da população recebe até 1⁄2 salário mínimo.

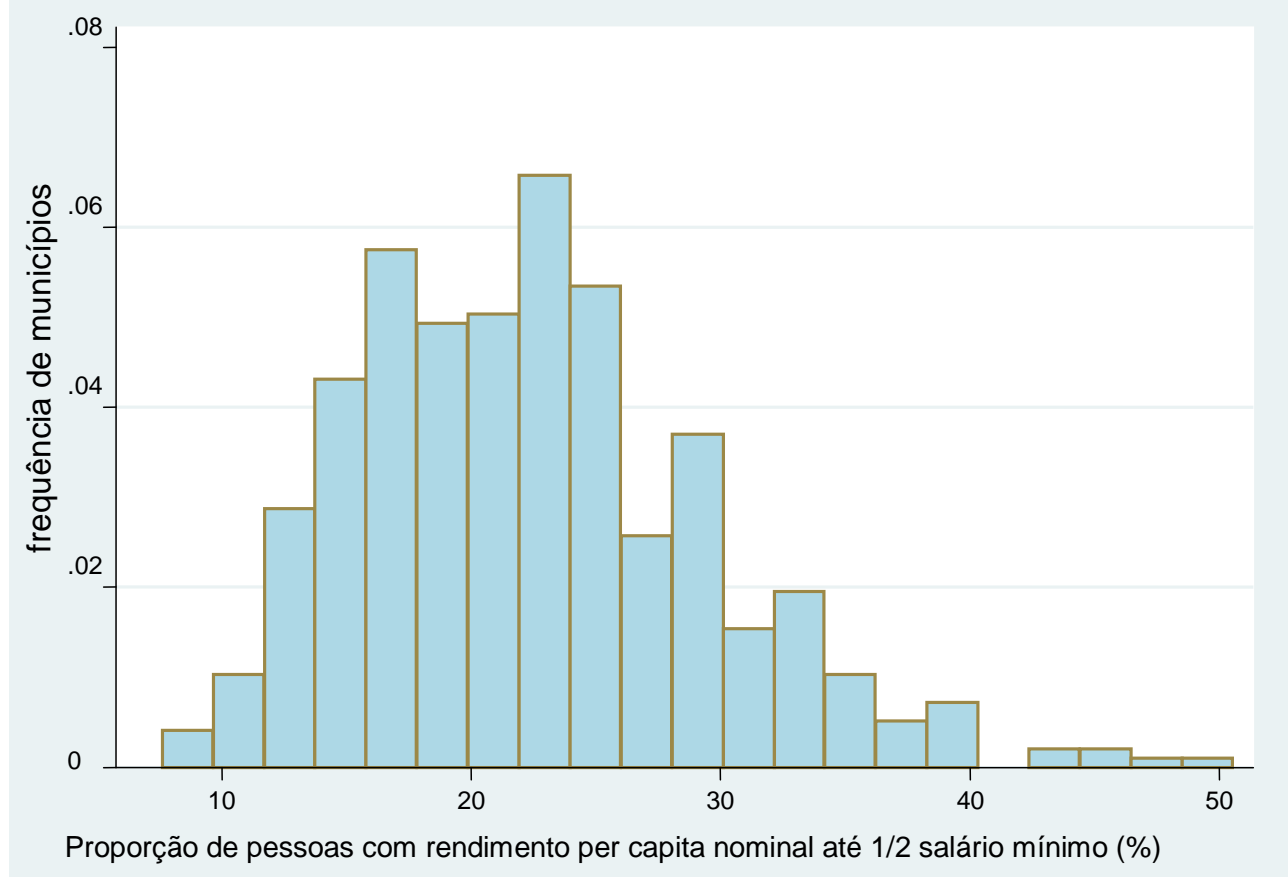

Gráfico 3 - Renda per capita (\%) municípios paulistas - 2010: proporção de pessoas residentes em domicílios particulares com rendimento mensal total per capita nominal até $1 / 2$ salário mínimo

Da mesma forma, observando se a Tabela 3 e o Gráfico 4 verificase que a proporção de analfabetismo na população com idade igual ou maior de 15 anos está entre 5\% e 10\% apresentando uma mediana de $7,6 \%$. 


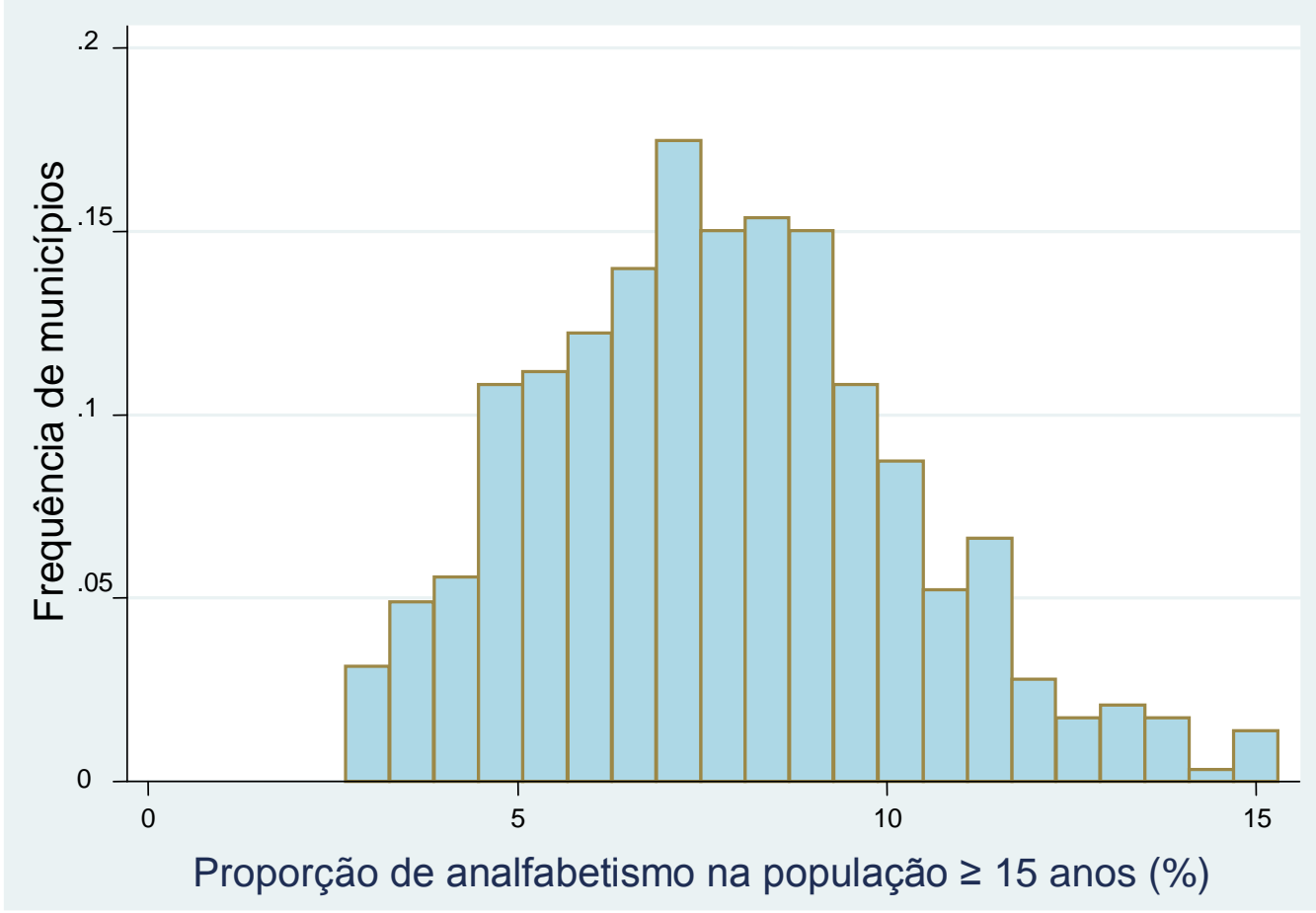

Gráfico 4 - Taxa de analfabetismo nos municípios paulistas - 2010, da população maior ou igual a 15 anos

Realizei a análise de correlação (Pearson) entre as variáveis socioeconômicas e os desfechos (Tabela 4) que se mostrou baixa. Somente a variável de analfabetismo mostrou maior correlação e demonstrou ser significativa para todos os desfechos.

Tabela 4 - Análise de Correlação (Pearson) entre as variáveis socioeconômicas e os desfechos nos municípios paulistas inseridos no modelo - 2010

\begin{tabular}{lcccc}
\hline Correlação & $\begin{array}{c}\text { RM t P } \\
(>65 \text { anos })\end{array}$ & $\begin{array}{c}\text { RM b P } \\
(<5 \text { anos })\end{array}$ & $\begin{array}{c}\text { RM b P } \\
(>65 \text { anos })\end{array}$ \\
\hline \hline \% Saneamento & $\mathbf{p}$ & $\mathbf{0 , 0 7 5}$ & $\mathbf{0 , 0 9 5}$ & $\mathbf{0 , 0 2 4}$ \\
\multirow{2}{*}{ \% Analfabetismo } & $\mathrm{p}$ & 0,102 & $\mathbf{0 , 0 3 8}$ & 0,605 \\
\multirow{2}{*}{ \% Renda até 1/2 SM } & $\mathrm{r}$ & $-0,130$ & 0,125 & 0,192 \\
& $\mathrm{p}$ & $\mathbf{0 , 0 0 4}$ & $\mathbf{0 , 0 0 6}$ & $<\mathbf{0 , 0 0 1}$ \\
& $\mathrm{r}$ & $-0,092$ & 0,070 & 0,055 \\
\hline
\end{tabular}

Observação: somente municípios do modelo. 


\subsection{Medidas de exposição à queima da palha de cana (PQM,} Focos, Aerossol), municípios paulistas (usados no modelo). Período abril a outubro de 2010.

Pela análise de correlação (Pearson) entre as medidas de exposição - Focos de Queima (Focos), Percentual (\%) de Queima Municipal (PQM) e Profundidade Óptica dos Aerossóis (Aerossol) observa-se independência entre elas (Tabela 5).

Tabela 5 - Análise de Correlação (Pearson) entre as Medidas de exposição (PQM, Focos e Aerossol) nos municípios paulistas - 2010.

\begin{tabular}{lccc}
\hline Correlação & & Aerossol & PQM \\
\hline \hline \multirow{2}{*}{ Focos de queima } & $r$ & 0,0662 & 0,3918 \\
& $\mathrm{p}$ & 0,0930 & 0,0001 \\
Aerossol & $\mathrm{r}$ & & 0,1122 \\
& $\mathrm{p}$ & & 0,0043 \\
\hline
\end{tabular}

E pela análise descritiva das mesmas (Tabela 6) se observa uma distribuição muito irregular da exposição nos municípios de São Paulo.

Tabela 6 - Análise descritiva das medidas de exposição (PQM, Focos e Aerossol) nos municípios paulistas - 2010.

\begin{tabular}{lrrccccr}
\hline Variável & Média & \multicolumn{1}{c}{ DP } & Mínimo & P25 & Mediana & P75 & Máximo \\
\hline \hline PQM & 7,80 & 9,15 & 0,00 & 0,00 & 4,69 & 11,57 & 47,59 \\
Focos & 33,71 & 70,20 & 0,00 & 0,00 & 6,00 & 38,00 & 950,00 \\
Aerossol & 0,33 & 0,55 & 0,19 & 0,30 & 0,33 & 0,37 & 0,49 \\
\hline
\end{tabular}

Observação: valores da Profundidade Ótica de aerossóis são interpretados da seguinte forma: de 0,0 a 0,3 = razoável; de 0,3 a 0,8 = poluído, e, acima de 0,8 = muito poluído.

A Tabela 7, também mostra baixa correlação entre medidas de exposição e os desfechos. 
Tabela 7 - Análise de Correlação (Pearson) das medidas de exposição (PQM, Focos e Aerossol) e os desfechos. nos municípios paulistas -2010 .

\begin{tabular}{lcccc}
\hline Correlação & & $\begin{array}{c}\text { RM t P } \\
(>65 \text { anos })\end{array}$ & $\begin{array}{c}\text { RM b P } \\
(<5 \text { anos })\end{array}$ & $\begin{array}{c}\text { RM b P } \\
(>65 \text { anos })\end{array}$ \\
\hline \hline Focos de & $\mathrm{r}$ & $-0,010$ & 0,036 & 0,007 \\
queima & $\mathrm{p}$ & 0,820 & 0,436 & 0,881 \\
Aerossol & $\mathrm{r}$ & $-0,007$ & $-0,054$ & $-0,101$ \\
& $\mathrm{p}$ & 0,878 & 0,238 & 0,027 \\
PQM & $\mathrm{r}$ & 0,077 & $-0,027$ & 0,038 \\
& $\mathrm{p}$ & 0,095 & 0,557 & 0,410 \\
\hline
\end{tabular}

7.4 Razões de Mortalidade (RMtP) e Morbidade (RMbP) Padronizadas para doenças respiratórias, municípios paulistas (usados no modelo). Período abril a outubro de 2010.

Pela descrição da Razão de Morbidade (internações) e Mortalidade (óbitos) Padronizada para os desfechos (óbitos $>65$ anos, internações $<5$ anos e internações >65 anos) apresentada na (Tabela 8) se observa grande dispersão de valores.

Tabela 8 - (RMtP) e (RMbP) p/ Doenças respiratórias, municípios paulistas Período abril à outubro de 2010.

\begin{tabular}{lccccccc}
\hline Variável & Média & DP & Mínimo & P25 & Mediana & P75 & Máximo \\
\hline \hline RMtP (Óbitos > 65 anos) & 0,96 & 0,59 & 0,00 & 0,61 & 0,93 & 1,24 & 4,64 \\
RMbP (Internações $<5$ & 1,18 & 0,96 & 0,00 & 0,56 & 0,92 & 1,52 & 7,61 \\
anos) & & & & & & & \\
RMbP (Internações> 65 & 1,58 & 1,07 & 0,00 & 0,86 & 1,39 & 2,08 & 8,63 \\
\hline anos) & & & & & & &
\end{tabular}


Portanto a $(\mathrm{RMtP})$ e $(\mathrm{RMbP})$ foram ajustados primeiramente com uso da matriz de vizinhança, e, depois foi feito o ajuste ao modelo composto pelo vetor de exposição à queima de palha de cana-de-açúcar. O ajuste foi feito separadamente para cada medida de exposição.

Após o ajuste para os demais parâmetros que podem influenciar nos desfechos os resultados da análise estatística de (RMtP) e (RMbP) é apresentada na Tabela 9, abaixo.

Tabela 9 - (RMtP) e (RMbP) Ajustada p/ Doenças respiratórias, nos municípios paulistas - Período abril a outubro de 2010

\begin{tabular}{|c|c|c|c|c|c|c|c|}
\hline Desfecho & Fator & Média & DP & P 2,5 & Mediana & P 97,5 & $p$ \\
\hline $\begin{array}{l}\text { Óbitos > } 65 \\
\text { anos }\end{array}$ & $\begin{array}{l}\text { PQM } \\
\text { Aerossol } \\
\text { Focos }\end{array}$ & & & & & & $\begin{array}{l}, 641 \\
, 477\end{array}$ \\
\hline $\begin{array}{l}\text { Inter } \\
<5 \text { a }\end{array}$ & $\begin{array}{l}\text { PQM } \\
\text { Aerosso } \\
\text { Focos }\end{array}$ & & & & & & $\begin{array}{l}0,800 \\
0,520 \\
\mathbf{0 , 0 0 8}\end{array}$ \\
\hline ternações & $\begin{array}{l}\text { PQM } \\
\text { Aeross } \\
\text { Focos }\end{array}$ & $\begin{array}{l}-0,43790 \\
-0,00004\end{array}$ & $\begin{array}{l}0,00450 \\
0,50950 \\
0,00028\end{array}$ & $\begin{array}{l}-0,00188 \\
-1,50800 \\
-0,00061\end{array}$ & $\begin{array}{r}0,00694 \\
-0,35150 \\
-0,00004\end{array}$ & $\begin{array}{l}0,01624 \\
0,38280 \\
0,00049\end{array}$ & $\begin{array}{l}0,116 \\
0,390 \\
0,872\end{array}$ \\
\hline
\end{tabular}

Valores ajustados para os demais parâmetros que podem influenciar nos desfechos

Essa análise revela existir uma associação estatisticamente significativa $(\mathbf{p = 0 , 0 0 8 )}$ entre o aumento do número de Focos de queima e as internações para crianças com menos de 5 anos para os municípios com queima de cana-de-açúcar do Estado de São Paulo, em 2010.

O ajuste feito, pelo modelo Bayesiano suaviza as variações aleatórias oque permite a interpretação visual do risco (Kato et al., 2009) no estado. A distribuição espacial da Razão de Mortalidade (RMtP) e Morbidade Padronizadas (RMbP) e Ajustadas, no Estado de São Paulo em 2010, pode ser visualizada por meio de mapas temáticos (Loch e 
Nogueira, 2006) ou coropléticos (Brasil-MS, 2007a). A diferença de tonalidade das cores mostra visualmente a localização dos agregados dos municípios em relação ao risco de doenças respiratórias.

Com os valores calculados pelo 'software' Winbugs construi os mapas (Figuras 7, 8 e 9) que representam a Razão de Morbidade Padronizada (RMbP), ajustada para indivíduos abaixo de cinco anos, . Eles permitem visualizar os municípios do estado de São Paulo agregados, conforme o grau de excesso de risco, comparado ao risco em todo estado, no ano de 2010. Risco apresentado devido à exposição aos focos de queima.

Apresentei os três mapas coropléticos das (RMbP), ajustadas para indivíduos abaixo de cinco anos, apesar dos resultados analíticos não terem sido significativos, quando a medida de exposição foi o PQM e o Aerossol. Entretanto, observo que esses desfechos apresentaram praticamente a mesma distribuição espacial em relação ao excesso de Risco para doenças respiratórias em indivíduos menores que cinco anos, daquela verificada quando foram usados os focos de queima como medida de exposição. 


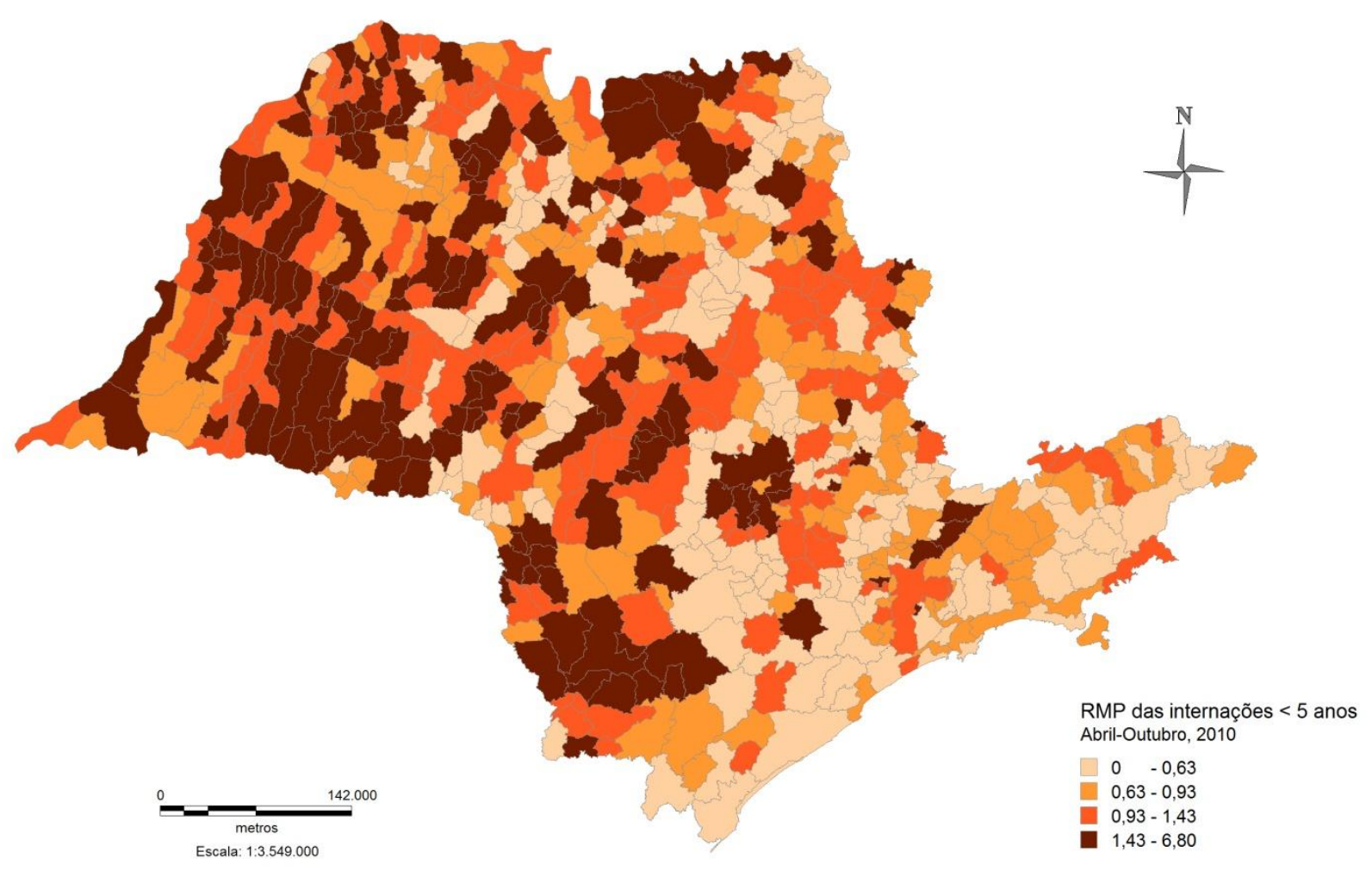

Figura 7 - Razão de Morbidade Padronizada (RMbP), ajustada para < 5 anos. Medida de exposição - Focos - SP 


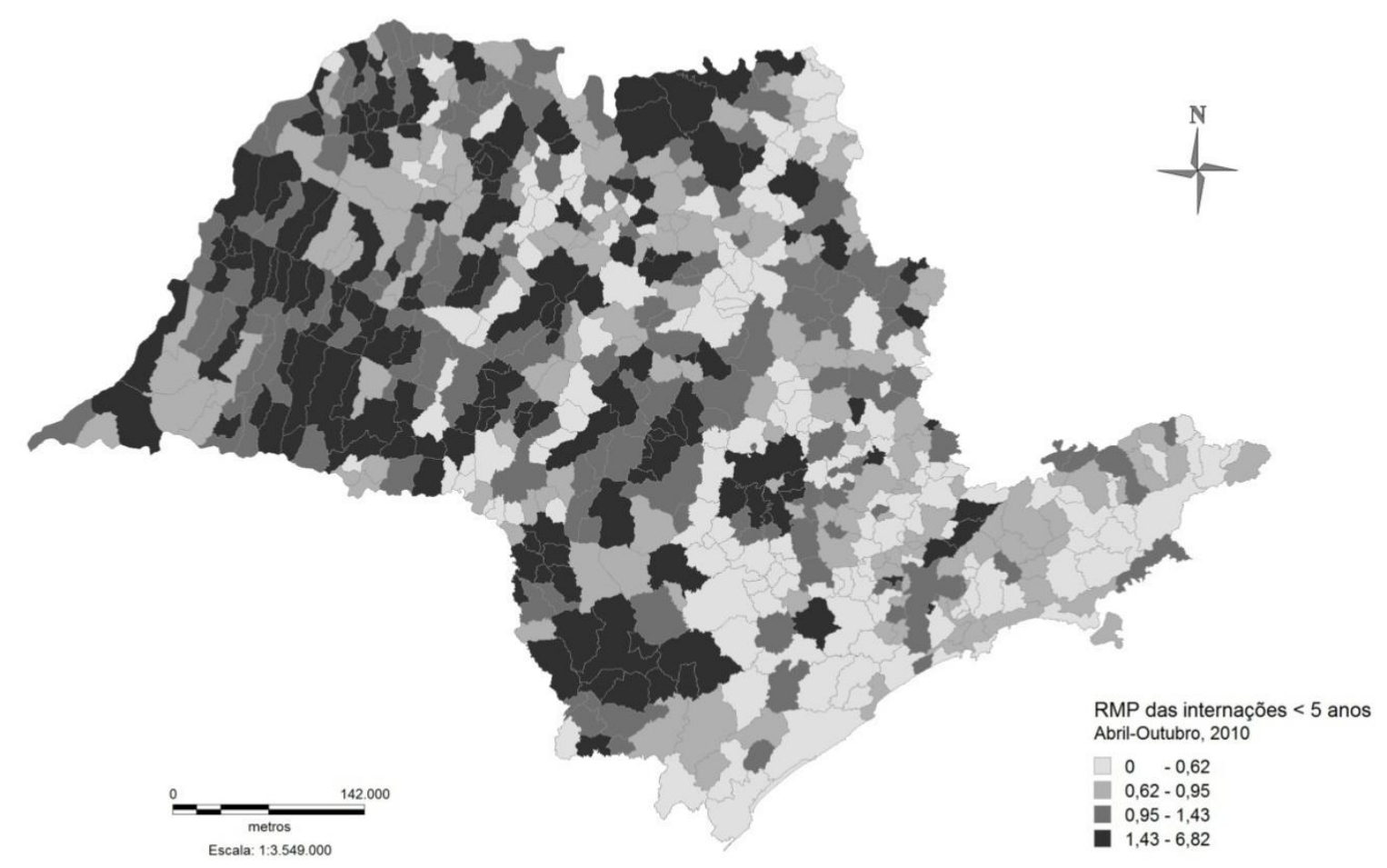

Figura 8 - Razão de Morbidade Padronizada (RMbP), ajustada para < 5 anos. Medida de exposição - Aerossóis, SP 


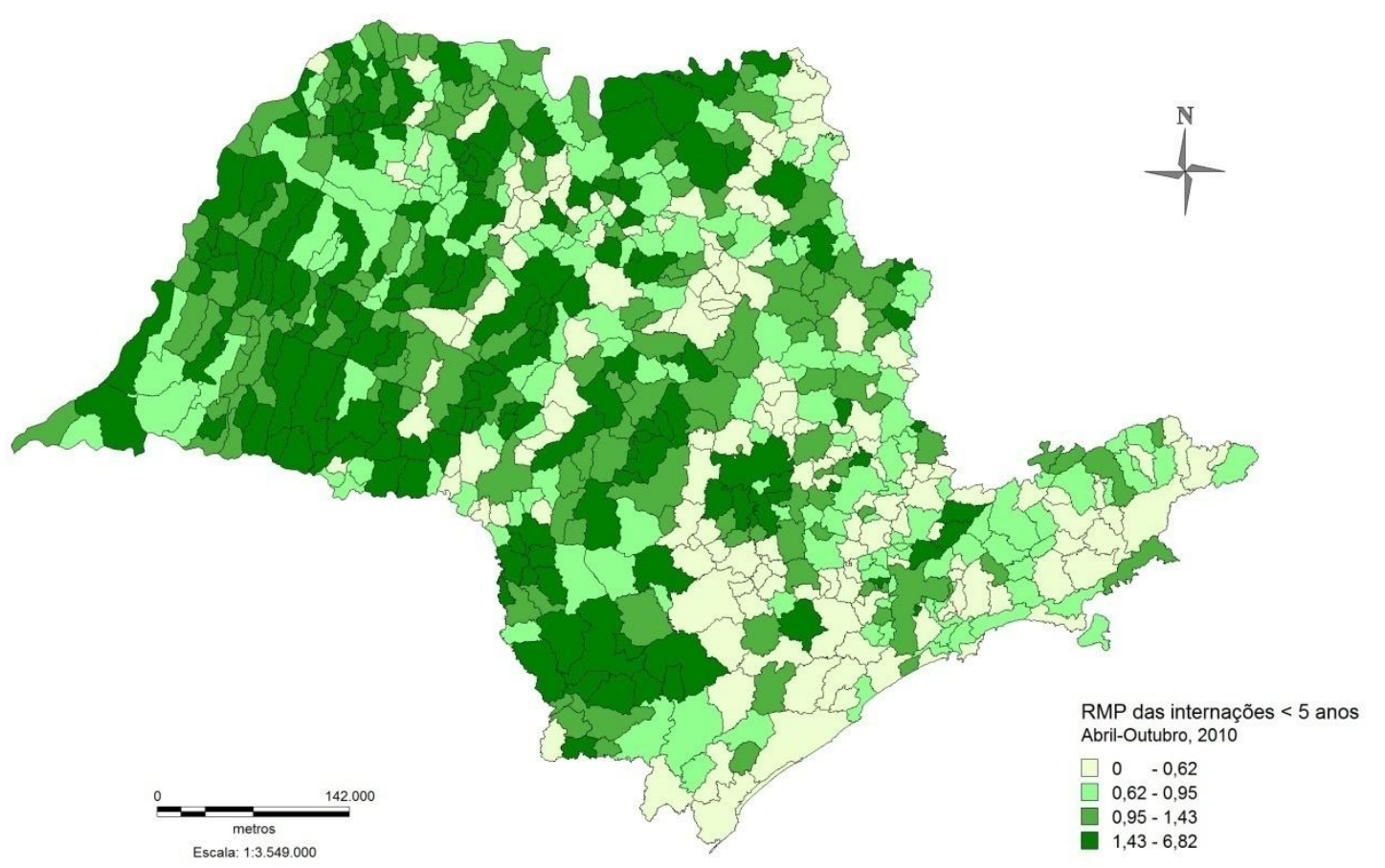

Figura 9 - Razão de Morbidade Padronizada $\left(\mathrm{RM}_{\mathrm{b}} \mathrm{P}\right)$, ajustada para $<5$ anos. Medida de exposição - PQM - SP 
Selecionei os municípios que se situaram no último quartil, ou que apresentaram RMbP maior que 1,42. Dividi por Mesorregião do Estado de São Paulo, e coloquei em ordem decrescente conforme os Quadros 1a, 1b e 1c abaixo. Esses são 145 cidades que compõem as Mesorregiões: São José do Rio Preto, Presidente Prudente, Bauru, Araçatuba, Assis, Ribeirão Preto, Marília, Piracicaba e Campinas. Na grande maioria existe 'queima prévia' de cana-de-açúcar. Nelas, incluem-se muitas cidades consideradas pequenas, com menos de 10.000 habitantes, onde não é realizado nenhum tipo de monitoramento de poluição do ar pelo órgão ambiental responsável. 


\begin{tabular}{|c|c|c|c|c|c|}
\hline \multicolumn{6}{|c|}{ Quadro 1a - Mesorregiões Administrativas e seus municípios com $\mathrm{RMbP}>1,42$ para doenças respiratórias } \\
\hline \multicolumn{6}{|c|}{ MESORREGIÃO } \\
\hline \multicolumn{2}{|c|}{ SÃO JOSE DO RIO PRETO } & \multicolumn{2}{|c|}{ PRESIDENTE PRUDENTE } & \multicolumn{2}{|c|}{ BAURU } \\
\hline MUNICÍPIOS & RMP & MUNICÍPIOS & RMP & MUNICÍPIOS & RMP \\
\hline NOVA GRANADA & 4,543 & SÃO JOÃO DO PAU D'ALHO & 3,894 & DUARTINA & 6,791 \\
\hline ONDA VERDE & 3,596 & TUPI PAULISTA & 3,565 & URU & 5,255 \\
\hline SÃO FRANCISCO & 2,535 & NOVA GUATAPORANGA & 3,553 & DOIS CÓRREGOS & 4,135 \\
\hline NOVO HORIZONTE & 2,433 & MONTE CASTELO & 3,387 & IGARAÇU DO TIETÊ & 3,283 \\
\hline VITÓRIA BRASIL & 2,403 & FLÓRIDA PAULISTA & 3,202 & AVARÉ & 2,608 \\
\hline POLONI & 2,158 & JUNQUEIRÓPOLIS & 2,809 & SÃO MANUEL & 2,373 \\
\hline SEBASTIANÓPOLIS DO SUL & 2,145 & RINÓPOLIS & 2,806 & CAFELÂNDIA & 2,341 \\
\hline SANTA ALBERTINA & 2,097 & TEODORO SAMPAIO & 2,627 & PROMISSÃO & 2,172 \\
\hline GUZOLÂNDIA & 2,027 & MARTINÓPOLIS & 2,614 & PONGAÍ & 1,904 \\
\hline ASPÁSIA & 1,989 & INDIANA & 2,598 & LUCIANËPOLIS & 1,834 \\
\hline PARANAPUÃ & 1,914 & IRAPURU & 2,454 & BARRA BONITA & 1,822 \\
\hline CAJOBI & 1,905 & ANHUMAS & 2,451 & MINEIROS DO TIETÉ & 1,796 \\
\hline IBIRÁ & 1,894 & PACAEMBU & 2,417 & BARIRI & 1,776 \\
\hline AURIFLAMA & 1,866 & SANTA MERCEDES & 2,097 & PRATÂNIA & 1,748 \\
\hline CARDOSO & 1,823 & PRESIDENTE EPITÁCIO & 1,986 & AGUDOS & 1,638 \\
\hline JALES & 1,774 & ADAMANTINA & 1,897 & AREIÓPOLIS & 1,617 \\
\hline PONTALINDA & 1,754 & RANCHARIA & 1,833 & CONCHAS & 1,542 \\
\hline SÃO JOÃO DE IRACEMA & 1,673 & SANTO ANASTÁCIO & 1,822 & PEDERNEIRAS & 1,494 \\
\hline
\end{tabular}




\begin{tabular}{|c|c|c|c|c|c|}
\hline \multicolumn{6}{|c|}{ Continuação MESORREGIÃO } \\
\hline \multicolumn{2}{|c|}{ SAO JOSE DO RIO PRETO } & \multicolumn{2}{|c|}{ PRESIDENTE PRUDENTE } & \multicolumn{2}{|c|}{ BAURU } \\
\hline JOSÉ BONIFÁCIO & 1,651 & SAGRES & 1,794 & BALBINOS & 1,454 \\
\hline MONTE APRAZÍVEL & 1,635 & CAIABU & 1,636 & & \\
\hline MARTINÓPOLIS & 1,624 & OSVALDO CRUZ & 1,62 & & \\
\hline DIRCE REIS & 1,599 & JOÃO RAMALHO & 1,607 & & \\
\hline TANABI & 1,595 & RIBEIRÃO DOS ÍNDIOS & 1,579 & & \\
\hline SANTA ADÉLIA & 1,557 & ESTRELA DO NORTE & 1,566 & & \\
\hline FERNANDÓPOLIS & 1,537 & TACIBA & 1,543 & & \\
\hline $\begin{array}{l}\text { SÃO JOÃO DAS DUAS } \\
\text { PONTES }\end{array}$ & 1,533 & SALMOURÃO & 1,519 & & \\
\hline TURMALINA & 1,498 & OURO VERDE & 1,515 & & \\
\hline PALMEIRA D'OESTE & 1,48 & PRACINHA & 1,481 & & \\
\hline NIPOÃ & 1,475 & SANTO EXPEDITO & 1,444 & & \\
\hline RUBINEIA & 1,475 & & & & \\
\hline TABAPUÃ & 1,442 & & & & \\
\hline OUROESTE & 1,432 & & & & \\
\hline
\end{tabular}

(Conclusão) 


\begin{tabular}{|c|c|c|c|c|c|c|c|}
\hline Quadro 1b-Con & Mesol & rregiões Administrativ & e seus & municípios com $\mathrm{F}$ & $\overline{\mathrm{lbP}>}$ & 1,42 para doenças & tórias \\
\hline & & & $\overline{M E}$ & SORREGIÃO & & & \\
\hline ARACATUBA & & ASSIS & & RIBEIRAO PRETO & & ITAPE] & \\
\hline MUNICÍPIOS & RMP & MUNICÍPIOS & RMP & MUNICÍPIOS & RMP & MUNICÍPIOS & RMP \\
\hline CASTILHO & 2,480 & SARUTAIÁ & 5,721 & MIGUELÓPOLIS & 5,547 & LARANJAL PAULISTA & 3,197 \\
\hline MIRANDÓPOLIS & 2,352 & PIRAJU & 3,262 & SERRANA & 2,873 & RIBEIRÃO BRANCO & 2,768 \\
\hline ANDRADINA & 2,095 & TEJUPÁ & 2,937 & MONTE AZUL PAULISTA & 2,790 & CAPÃO BONITO & 2,748 \\
\hline BORBOREMA & 2,039 & PARAGUAÇU PAULISTA & 2,850 & PIRANGI & 2,421 & ITAPEVA & 2,721 \\
\hline LAVÍNIA & 1,927 & NANTES & 2,839 & CÂNDIDO RODRIGUES & 2,405 & TAQUARIVAÍ & 2,678 \\
\hline GUARARAPES & 1,914 & FARTURA & 2,031 & BATATAIS & 2,393 & TAQUARITUBA & 2,347 \\
\hline TRABIJU & 1,846 & TAGUAÍ & 1,987 & COLÔMBIA & 2,325 & NOVA CAMPINA & 2,233 \\
\hline AVANHANDAVA & 1,770 & ASSIS & 1,840 & CAJURU & 2,222 & ANGATUBA & 2,126 \\
\hline SUZANÓPOLIS & 1,758 & PLATINA & 1,823 & BARRETOS & 2,171 & ITABERÁ & 1,873 \\
\hline $\mathrm{BRA}_{\Gamma} \mathrm{NA}$ & 1,728 & LUTÉCIA & 1,631 & ORLÂNDIA & 2,074 & RIBEIRA & 1,694 \\
\hline BURITAMA & 1,722 & MARACAÍ & 1,605 & TAQUARITINGA & 2,002 & BARÃO DE ANTONINA & 1,628 \\
\hline LUIZIÂNIA & 1,714 & \begin{tabular}{|l} 
PALMITAL \\
\end{tabular} & 1,587 & GUAÍRA & 1,889 & GUAPIARA & 1,614 \\
\hline MURUTINGA DO SUL & 1,570 & CAMPOS NOVOS PAULISTA & 1,537 & IGARAPAVA & 1,880 & RIBEIRÃO GRANDE & 1,540 \\
\hline BILAC & 1,533 & IEPÉ & 1,445 & MORRO AGUDO & 1,644 & ITARARÉ & $\overline{1,502}$ \\
\hline RIBEIRÃO BONITO & 1,515 & CÂNDIDO MOTA & 1,436 & & & & \\
\hline PENÁPOLIS & 1,440 & & & & & & \\
\hline
\end{tabular}




\begin{tabular}{|c|c|c|c|c|c|}
\hline \multicolumn{6}{|c|}{ Quadro 1c-Cont. Mesorregiões Administrativas e seus municípios com RMbP >1,42 para doenças respiratórias } \\
\hline \multicolumn{6}{|c|}{ MESORREGIÃO } \\
\hline \multicolumn{2}{|c|}{ MARILIA } & \multicolumn{2}{|c|}{ PIRACICABA } & \multicolumn{2}{|l|}{ CAMPINAS } \\
\hline MUNICÍPIOS & RMP & MUNICÍPIOS & RMP & MUNICÍPIOS & RMP \\
\hline ÁLVARO DE CARVALHO & 5,842 & CONCHAL & 3,280 & SÃO SEBASTIÃO DA GRAMA & 3,058 \\
\hline BASTOS & 5,659 & TIETÉ & 2,712 & TAPIRATIBA & 2,244 \\
\hline GARÇA & 3,769 & MOMBUCA & 1,641 & JAGUARIÚNA & 1,804 \\
\hline VERA CRUZ & 2,613 & RIO DAS PEDRAS & 1,634 & ÁGUAS DE LINDOIA & 1,543 \\
\hline TUPÍ & 2,591 & JUMIRIM & 1,507 & HORTOLÂNDIA & 1,431 \\
\hline HERCULÂNDIA & 2,453 & PIRACICABA & 1,462 & & \\
\hline LUPÉRCIO & 2,238 & & & & \\
\hline ALVINLÂNDIA & 1,901 & & & & \\
\hline OCAUÇU & 1,784 & & & & \\
\hline IACRI & 1,691 & & & & \\
\hline FERNÃO & 1,605 & & & & \\
\hline
\end{tabular}




\section{DISCUSSÃO}




\section{DISCUSSÃO}

Este estudo, bem como outros realizados no Estado de São Paulo (Arbex et al. 2000; Cançado et al. 2006; Roseiro, 2002; Lopes et al. 2006; Uriarte et al., 2009) demonstra que existe associação entre a queima prévia da palha de cana-de-açúcar e a ocorrência de doenças respiratórias, especialmente em crianças menores de cinco anos. A análise geoespacial da distribuição da Razão de Morbidade Padronizada (RMbP) e ajustada mostrou que o aumento nos focos de queima (Focos) esteve associado significativamente com o aumento das internações por doenças respiratórias, na faixa etária de menores de cinco anos. Assim, para cada incremento de um foco de queima, a RMbP para internações por doenças respiratórias em $<5$ anos aumenta em média 0,0008.

Por utilizarem metodologia diferente da aqui empregada, não foi possível comparar diretamente meus resultados com aqueles obtidos por Uriarte (2009) e Lopes (2006) apesar do objeto de estudo comum. Entretanto, ambos os autores encontram resultados concordantes com o do presente trabalho, indicando associação entre queima da palha de cana-de-açúcar e doenças respiratórias em crianças.

O mapa temático ou coroplético construído apresentou os diferenciais de risco da doença no Estado de São Paulo. Os resultados dispostos nos Quadros 1a, 1b e 1c apresentaram as Mesorregiões e os municípios do estado onde ocorre número excedente de casos de 
doenças respiratórias $(\mathrm{RMbP}>1,42)$. Essa lista confirma a existência de muitas cidades pequenas com alto risco para doenças respiratórias, o que vem a confirmar a necessidade de se proceder também à medição, pelo órgão de controle oficial, dos poluentes atmosféricos para essas cidades impactadas pela queima de palha de cana-de-açúcar.

Os estudos ecológicos sofrem limitações devido ao uso de dados agregados, pois não oferecem possibilidade de se aplicar os resultados obtidos diretamente para o nível individual. Esse tipo de limitação é conhecido como falácia ecológica. Com base em Rose (1985, p.33), “as causas das doenças nos indivíduos é diferente das causas de incidência na população", examinei a diferença nas taxas de adoecimento nos 645 municípios do Estado de São Paulo, para verificar o efeito da 'queima prévia' da palha da cana-de-açúcar. Porém, considerando a condição de saúde da população de cada município e não de cada indivíduo, este estudo pode oferecer resultados efetivos e aplicáveis na definição de políticas públicas de saúde. Assim, mesmo não sendo possível afirmar que as internações tiveram a prática da queima prévia da palha da canade-açúcar como causa do adoecimento, pode-se através desse tipo de estudo obter Mapas (Figuras 7, 8 e 9) que mostrem o excesso de risco de adoecimento por doenças respiratórias distribuídas territorialmente no estado de São Paulo.

Este estudo fez uso das ferramentas de análise espacial, para controle da autocorrelação, o que permitiu estudar, ao mesmo tempo, a influência de muitas variáveis que podem ter influência no processo de adoecimento. Desse modo, a questão da saúde foi analisada por uma 
perspectiva completamente ecológica (Rothman, 2011), ou seja, todas as variáveis (exposição, doença e covariáveis) usadas foram medidas ecológicas, do agregado considerado (município), tomando a saúde e a doença no contexto ambiental e socioeconômico. O uso da matriz de vizinhança para análise espacial permitiu também verificar a influência dos municípios com seus vizinhos.

A não eliminação dos casos de doenças respiratórias devido ao cigarro/tabaco se justifica pelo seu efeito homogêneo sobre a população. Ainda como realizei uma análise estratificada por faixa etária, sendo que o dado significativo foi para menores de cinco anos, o problema se reduziu ao eventual fumo passivo. Além disso, considero que o mesmo tipo de problema poderia ocorrer em todos os municípios, independente da queima prévia ou não da palha. Portanto, isso pode ter ocasionado apenas um erro de classificação não diferencial (Rothman, 2011).

Quanto aos dados climáticos usados, o acesso ao SISAM/INPE possibilitou a obtenção de dados individualizados para cada município, o que aumenta a qualidade da análise. Essa poderia ser ainda mais acurada, caso fossem utilizadas em vez de dados anualizados, informações climáticas mensais, como realizado no trabalho de Uriarte et al. (2009).

Uma possibilidade de melhorar as estimativas seria a troca das medidas de exposição usadas. O uso da (PQM), que carrega um erro devido ao uso do valor porcentual, e das áreas dos municípios variarem muito, podendo levar uma área de queima grande a representar proporcionalmente pouco em um município grande -, poderia ser 
substituído pela área bruta de colheita com queima no município, ou pelo valor das emissões do setor canavieiro, calculadas a partir do novo fator de emissão da queima obtido pelo INPE (França et al., 2012).

O conhecimento científico atual demonstra que a poluição do ar gera diversos danos à saúde, além das doenças respiratórias, por exemplo, doenças cardiovasculares (Arbex et al., 2010) e câncer (Pope III et al., 2002; Fajersztajn et al. 2013). Apesar disso, neste estudo, optei por usar somente o desfecho doenças respiratórias. Portanto, o impacto na saúde devido à queima prévia de cana-de-açúcar está certamente subestimado.

As variáveis socioeconômicas usadas para controlar as diferenças entre os municípios foram as de Educação, Saneamento e Renda, . do CENSO 2010,que foi o mesmo período das informações de desfecho e exposição coletadas, garantindo, desse modo, melhor acurácia às análises.

Considerei usar o Índice de Desenvolvimento Humano Municipal, IDH-M, indicador composto desenvolvido pelo Programa das Nações Unidas e Meio Ambiente (PNUMA). Ele contabiliza três dimensões do desenvolvimento humano: expectativa de vida, educação e renda. Para tal analisa 180 indicadores socioeconômicos sob a perspectiva municipal. No entanto, quando foram realizadas as análises, o IDH-M disponível tinha como base os dados do CENSO 2000. Por isso, julguei que ele expressaria uma situação socioeconômica muito desatualizada dos municípios pesquisados. 
Como simplificação da realidade, uma modelagem tem sempre como ser aprimorada e, segundo Box (1983) ela nunca está certa. De qualquer modo, ainda que as limitações levantadas sejam pertinentes, isso não invalida os resultados encontrados.

Este estudo pode contribuir para a adoção de políticas públicas claras no sentido da eliminação da queima como prática agrícola, assim como garantir o direito à saúde e ao meio ambiente equilibrado para toda a população, como disposto na Constituição Federal, de 1988 (Brasil, 1989). Ressalto que a adoção, pelo setor sucroenergético paulista, da proposta de eliminação da queima prévia da palha de cana-de-açúcar o Protocolo Agroambiental (Única, 2007) deveria servir como exemplo de responsabilidade social e ambiental para os outros estados do Brasil onde se pratica a queima prévia da palha de cana-de-açúcar (Rudorff et al, 2010). Mas, como essa iniciativa ainda não se tornou Lei, sendo apenas um acordo, é importante acompanhar seus desdobramentos e verificar os avanços ou não nesta área. Essa atenção é valida também para outros setores da agricultura nos quais as queimadas são prática comum e os esforços do governo para eliminação da prática tem tido pouco sucesso. (Sá et al., 2007).

A Secretaria de Vigilância em Saúde do Ministério da Saúde implantou o Programa Vigiar (Brasil, MS, 2007b) para mensurar, avaliar e prevenir riscos à saúde da população exposta aos fatores ambientais relacionados à poluição atmosférica. Os resultados produzidos neste trabalho mostraram que a queima prévia da palha da cana-de-açúcar oferece efetivamente risco à saúde da população e, adicionados aos 
mapas gerados, pode oferecer subsídios para a vigilância epidemiológica e contribuir para o estabelecimento de políticas de controle da poluição do ar que contemplem além dos grandes centros urbanos, os pequenos municípios.

Outra questão a ser considerada é o fato de as medições do nível de poluição do ar realizadas no interior do Estado de São Paulo, por meio da rede automática serem somente em 12 cidades grandes, apenas para $\mathrm{PM}_{10}$, e, de modo geral, realizadas nas áreas centrais de grandes cidades, com o objetivo de captar a poluição veicular. Desse modo, não são medidos adequadamente os poluentes emitidos pela queima da palha da cana-deaçúcar (Roseiro e Takayanagui, 2006).

Observo também que as ações judiciais movidas nas 'cidades canavieiras' para eliminação da queima são julgadas improcedentes, porque se alega falta de evidência para justificar sua proibição (Gonçalves, 2005). De acordo com Avólio (2002), as poucas ações consideradas procedentes foram julgadas no âmbito do princípio da precaução (Gonçalves, 2005), o qual visa a garantir a defesa contra potenciais riscos que ainda não foram cientificamente comprovados no estado atual do conhecimento (Goldim, 2002). Argumentos como os usados em Queima da cana e legislação ambiental: quando a preservação do meio ambiente coloca em risco a possibilidade da sobrevivência humana (Gonçalves e Souza, 2009), os quais alegam falta de correlação entre a queima prévia da palha de cana-de-açúcar e os impactos deletérios sobre a saúde da população deverão ser revistos. 
CONCLUSÃO 


\section{CONCLUSÃO}

A decisão de queimar ou não queimar a palha da cana-de-açúcar deveria ser tratada não somente como uma questão de ordem econômica, política, social e ambiental, mas também como um problema de saúde. Essa discussão traz à baila o atual e recorrente tema do desenvolvimento atrelado à preservação do meio ambiente e da qualidade de vida. Ao abordar a atividade da queima de cana-de-açúcar sobre a saúde da população do Estado de São Paulo, procurei fazer um estudo da distribuição de um fator econômico, a 'queima de palha de cana-de-açúcar', na saúde da população. Isso está de acordo com Shy (1997) que entende a doença como consequência do comportamento da sociedade e dos impactos sociais e econômicos das forças do mercado na incidência de doenças.

Deve-se reconhecer o mal gerado pela queima prévia da palha de cana-de-açúcar na saúde da população dos municípios canavieiros. Os dados de colheita com queima nos municípios e os indicadores de morbidade e mortalidade por doenças respiratórias analisadas subsidiam a defesa da eliminação da queima prévia da cana-de-açúcar e sua substituição pelo corte de cana-de-açúcar sem queima (GH). Em vista dos resultados obtidos no presente estudo, a eliminação da queima prévia da palha da cana-de-açúcar demonstrou ser uma medida necessária para melhoria da saúde da população do Estado de São Paulo. 
Diante das evidências de que a exposição aos poluentes atmosféricos apresenta um impacto mensurável sobre as populações humanas, torna-se necessária a execução da vigilância epidemiológica sobre as populações expostas à queima. 
REFERÊNCIAS BIBLIOGRÁFICAS 


\section{REFERÊNCIAS BIBLIOGRÁFICAS}

Abramovay R. (organizador) Biocombustíveis energia da controvérsia. São Paulo: Editora SENAC, 2009.

Aguiar DA, Rudorff BFT, Silva WF, Adami M, Mello MP. Remote sensing images in Support of Environmental Protocol: Monitoring the Sugarcane Harvest in São Paulo State, Brazil. Remote Sensing. 2011 ;3:2682-2703.

Aguiar DA, Adami M, Rudorff BFT, Shimabukuro YE. Imagens de sensoriamento remoto no monitoramento da colheita da cana-de-açúcar. Eng. Agrícola. 2009; 29 (3):440-451.

Aguiar DA, Adami M, Rudorff BFT, Sanchez GA, Barros MA, Sugawara LM, Shimabukuro YE, Moreira MA. Mapeamento da colheita da cana-deaçúcar no Estado de São Paulo: ano safra 2006/2007. São José dos Campos: INPE; 2007.

Allen AG, Cardoso AA, Da Rocha GO. Influence of sugar cane burning on aerosol soluble composition in southeastern Brazil. Atmospheric Environment. 2004; 38: 5025-5038.

Alves FJC. Por que morrem os cortadores de cana? Saúde e Sociedade. São Paulo. 2006; 15; 90-98.

Alves FJC. Modernização da agricultura e sindicalismo: a luta dos trabalhadores rurais da região canavieira de Ribeirão Preto [tese]. Campinas: Instituto de Economia da Universidade de Campinas; 1991.

Alves F, Gusman Ferraz JM, Guedes Pinto LCG, Sczmercsányi T (org.). Certificação Socioambiental para a Agricultura: Desafios para o setor sucroalcooleiro. Piracicaba-SP: IMAFLORA; São Carlos: Edufscar; 2008.

Alves FJC, Alves M. Crise e perspectivas do setor sucroalcooleiro no Estado de São Paulo. In: Ferraz J, Prada L, Paixão M (Ed.). Certificação socioambiental do setor sucroalcooleiro. São Paulo: Embrapa/ Imaflora / Fase, 2000.

Arbex MA, Martins LC, Oliveira RC, Pereira LAA, Arbex FF, Cançado JED. Impact of outdoor biomass air pollution on hypertension hospital. $J$ Epidemiol Comm. Health. 2010:573-579.

Arbex MA, Martins LC, Oliveira RC, Pereira LAA, Arbex FF, Cançado JED. Air pollution from biomass burning and asthma hospital admissions in a 
sugar cane plantation area in Brazil. J Epidemiol Community Health. 2007:395-400.

Arbex MA, Cançado JRD, Pereira LAA, Braga ALF, Saldiva PHN. Queima de biomassas e efeito sobre a saúde. J Bras Pneumol. 2004; 30: 158-175.

Arbex MA, Bohn GM, Saldiva PH, Conceição GM, Braga AL, Pope III AC. Assessment of the effects of sugar cane plantation burning on daily counts of inhalation therapy. J Air Waste Manag. Assoc. 2000;50: 1745-1749.

Artaxo P, Martins JW, Yamasoe MA, Procópio AS, PauliquevisTM, Andrea MO, Guyon P, Gatti LV, Leal AMC. Physical and chemical properties of aerosols in the wet and dry seasons in: Rondonia Amazonia. $J$. Geophys.Res. 2002;107:8081-8095.

Avólio EG. Da (i)licitude das queimadas da palha da cana-de-açúcar. [Dissertação] São Carlos- São Paulo: Escola de Engenharia de São Carlos- Universidade de São Paulo; 2002.

Beaglehole R, Bonita R, Alleyne G, Horton R, Li LM, Lincoln P, Mbanya JC, McKee M, Moodie R, Nishtar S, Piot P, Reddy KS, Stuckler D, for The Lancet NCD Action Group, UN High-Level Meeting on Non-Communicable Diseases: addressing four questions, The Lancet. 2011;378(9789):449455.

Belik W. A tecnologia em um setor controlado. O caso da agroindústria canavieira em São Paulo. Cadernos de Difusão de Tecnologia. 1985; 2(1):99-135.

Bell ML, Cifuentes LA, Davis DL, Cushing G, Telle A, Gouveia N. Environmental health indicators and a case study of air pollution in Latin American cities. Environm. Res. 2011; 111:57-66.

Bernardinelli L, Montomoli C. Empirical Bayes versus Fully Bayesian Analysis of Geographical Variation in Disease Risk. Statistics in Medicine. 1992;11: 983-1000.

Boopathy R, Asrabadi BR, Ferguson TG. Sugar cane (Saccharum officinarumm) L. Burning and asthma in Southeast Louisiana, USA. Bull Environ Contam. Toxicol. 2002; 68(2):173-179.

Box GEP. In: Box GEP, Leonard T, Wu CF (Eds.) Scientific Inference, Data analysis, and Robustness. New York: Academic Press, 1983.

Brasil. Constituição, 1988. Constituição da República Federativa do Brasil 1988. São Paulo: Revista dos Tribunais, 1989. 
Brasil. Ministério do Meio Ambiente. RESOLUÇÃO CONAMA n 3, de 28 de junho de 1990. Publicada no DOU, 22 de agosto de 1990, Seção 1, páginas 15937-15939.

Brasil. Secretaria Geral da Presidência da República. Compromisso nacional para aperfeiçoar as condições de trabalho na cana-de-açúcar. Disponível em http://www.secretariageral.gov.br/compromisso-da-cana.

Brasil. Ministério da Saúde. DATASUS. Processamento de dados do SUS. Procedimentos hospitalares do SUS. Disponível em: http://tabnet.datasus.gov.br.

Brasil. Ministério da Saúde. DATASUS. Informações sobre mortalidade e informações demográficas. Disponível em: http://tabnet.datasus.gov.br/cgi/tabcgi.

Brasil. Ministério da Saúde. Secretaria de Vigilância em Saúde. Fundação Oswaldo Cruz. Introdução à Estatística Espacial para a Saúde Públical Ministério da Saúde, Fundação Oswaldo Cruz; Simone M. Santos, Wayner V. Souza (org.). Brasília, DF: MS, 2007a. (Série B. Textos Básicos de Saúde) (Série Capacitação e Atualização em Geoprocessamento em Saúde; Vol. 3)

Brasil. Ministério da Saúde. Vigiar - instrumento de identificação de município em risco. Brasília (DF): Secretaria de. Vigilância em Saúde/ Coordenação Geral de Vigilância em Saúde; 2007b.

Brasil. Ministério do Planejamento, Orçamento e Gestão. Instituto Brasileiro de Geografia e Estatística, IBGE. Indicadores Sociais Municipais. Uma análise dos resultados do universo do Censo Demográfico. Rio de Janeiro: FIBGE, 2011. (Informação Demográfica e Socioeconômica, 28).

Brasil. Planalto. Decreto 6.961/2009. Zoneamento agroecológico da canade-açúcar. Diário Oficial da União. Brasília, DF, 18 set 2009. p.1.

Cançado JE. A poluição atmosférica e sua relação com a saúde humana na região canavieira de Piracicaba - SP. [tese] São Paulo: Faculdade de Medicina da Universidade de São Paulo, 2003.

Cançado JE, Braga A, Pereira LA, Arbex MA, Saldiva PH, Santos UP. Repercussões clínicas da exposição à poluição atmosférica. $J$ Bras Pneumol. 2006; 32(Supl. 2):S5-S11.

Carmo CN, Hacon S, Longo KM, Freitas S, Ignotti E, Ponce de Leon A, Artaxo P. Associação entre material particulado de queimadas e doenças respiratórias na região sul da Amazônia brasileira. Rev. Panam. Salud Publica. 2010; 27:10-16. 
Carson R. Primavera silenciosa. Tradução: Claudia Santana Martins. São Paulo: Gaia, 2010.

Castro NJ, Brandão R, Dantas GA. A bioeletricidade sucroenergética na matriz elétrica. In: Souza ELL, Macedo IC (coord.) Etanol e a bioeletricidade: a cana-de-açúcar no futuro da matriz energética. São Paulo: Luc Projetos de Comunicação, 2010. p. 135-153.

Ciocco A, Thompson, DJ.A follow-up on Donora ten years after: Methodology and findings. Am. J. Public. Health. 1961:51; 155-164.

Clancy L, Goodman P, Sinclair H, Dockery DW. Effects of air-pollution control on death rates in Dublin, Ireland in intervention study. Rev. Bras. Epidemiol. 2003; 6: 135-149.

Companhia Nacional de Abastecimento, Conab. Acompanhamento de safra brasileira: cana-de-açúcar, terceiro levantamento, janeiro/2011. Brasília (DF): Conab; 2011.

Dinardo-Miranda LL, Vasconcelos ACM, Landelletal MGA. Cana de açúcar. Campinas, SP:Instituto Agronômico de Campinas, IAC, 2008.

Dockery D W, Pope III C A, Xu X, Spengler J D, Ware J H, Fay M E, Ferris $B$ G, Speizer $F$ E. An association between air pollution and mortality in six U.S. cities. N. Engl. J. Med. 1993;329:1753-1759.

Embrapa. Monitoramento por Satélite. Impacto ambiental da cana-deaçúcar. Disponível em: <http://www.cana.cnpm.embrapa.br/index.html>

Ezzati M, Riboli. E. Can No communicable diseases be prevented? Lessons from studies of populations and individuals.Science.2012; 337(6101):1482-1487.

Espírito Santo (Estado). Lei no 9.073, de 04 de dezembro de 2008. Dispõe sobre a eliminação gradativa da prática de queimadas nas colheitas de cana-de-açúcar e dá outras providências. Vitória: Assembleia Legislativa do Estado do Espírito Santo; 04 dez 2008. Disponível em: http://www.al.es.gov.br/antigo_portal_ales/images/leis/html/LO9073.html

Facioli II (org.). Vozes do Eito. Guariba, SP: Eco das letras. (Coletânea de depoimentos sobre a vivência cotidiana de migrantes temporários rurais); 2009.

FAOSTAT. 2011. Food and Agriculture Organization of the United Nations, Statistical Databases. Disponível em: http://faostat.fao.org/.

Fajersztajn L, Veras M, Barrozo LV, Saldiva P. Air pollution: a potentially modifiable risk factor for lung câncer. Nature Reviews Cancer. 2013;13:674-678. 
Ficarelli TR, Ribeiro H. Queimadas nos canaviais e perspectivas dos cortadores de cana-de-açúcar em Macatuba, São Paulo. Rev. Saúde Soc. 2010.19:48-63.

Fircket J. Sur les causes des accidents survenus dans la vallée de la Meuse, lors des brouillards de décembre1930. Bull Acad R Med Belg. 1931;11:683-741.

França DA, Longo KM, Neto TGS, Santos JC, Freitas SR, Rudorff BFT, Cortez EV, Anselmo E, Carvalho Jr JA. Pre-harvest sugarcane burning: determination of emission factors through laboratory measurements. Atmosphere. 2012;3:164-180.

Freitas SR, Longo K, Silva Dias MAF, Chatfield R, Artaxo P, Andreae MO, Grell G, Rodrigues LF, Fazenda A, Panetta J. The coupled aerosol and tracer transport model to the Brazilian developments on the regional atmospheric modeling system (CATT-BRAMS). Part 1: Model description and evaluation. Atmosph Chem Phys Discuss; 2007: 7.

Galdos MV, Cerri CC, Rattan LAL, Bernoux MAL, Brigitte FEIGL, Cerri CEP.Net greenhouse gas fluxes in Brazilian ethanol production systems. Bioenergy. 2010;2:37-44.

Goldim JR.O princípio da precaução. Núcleo Interdisciplinar de Bioética da UFRGS. 2002. Disponível em: http://www.bioetica.ufrgs.br/precau.htm.

Gonçalves DB. Sob as cinzas dos canaviais: o perigoso impasse das queimadas no Estado de São Paulo. Informações Econ. 2005;35(8):3243.

Gonçalves JS, Souza SAM. Queima da cana e legislação ambiental: quando a preservação do meio ambiente coloca em risco a possibilidade da sobrevivência humana. Texto Discussão nํ-9- São Paulo -IEA, 2009.

Gouveia NC, Fletcher T. Respiratory diseases in children and outdoor air pollution in São Paulo, Brazil: a time series analysis. Occup Environ Med 2000a;57: 477-83.

Gouveia NC, Fletcher T. Time series analysis of air pollution and mortality: effects by cause, age and socioeconomic status. J Epidemiol Commun Health.2000b;54:750-755.

Gouveia NC, Freitas CU, Martins LC, Marcilio IO. Respiratory and cardiovascular hospitalizations associated with air pollution in the city of São Paulo, Brazil. Cad. Saúde Pública. 2006; 22:2669-77.

Graziano SJ. Progresso técnico e relações de trabalho na lavoura canavieira. São Paulo: Ed. Hucitec, 1981. 
Health Effects Institute (HEI). Benchmark Study Finds Ambient Air Pollution Among Top Global Health Risks. HEI Update. Winter 2012-2013. p.4-5.

Ignotti E, Hacon SS, Silva AMC, Junger WL, Castro H. Efeitos das queimadas na Amazônia: método de seleção dos municípios segundo indicadores de saúde. Rev. Bras Epidemiol. 2007;10:453-464.

Jank M, Nappo M. Etanol de cana de açúcar: uma solução energética global sob destaque. In: Biocombustíveis: A energia controversa. São Paulo: Editora SENAC, 2009. p. 20-53.

Kato SK, Vieira DM, Fachel JMG. Utilização da modelagem inteiramente bayesiana na detecção de padrões de variação de risco relativo de mortalidade infantil no Rio Grande do Sul, Brasil. Cad. Saúde Pública [online]. 2009;25(7):1501-1510.

Krewski D, Burnett R, Jerrett M, Pope CA, Rainham D, Calle E, Thurston G, Thun M. Mortality and long-term exposure to ambient air pollution: ongoing analyses based on the American cancer society cohort. Journal of Toxicology and Environmental Health, Part A. 2005; 68:1093-1109.

Krewski D, Burnett R, Jerrett $M$, Goldberg $M$, Hoover BC, Siemiatycki J, Abrahamowicz M, White W .Overview of the Reanalysis of the Harvard Six Cities Study and American Cancer Society Study of Particulate Air Pollution and Mortality, Journal of Toxicology and Environmental Health, Part A: Current Issues. 2003;66:16-19, 1507-1552.

Marques F. A escalada do etanol: Articulação dos pesquisadores paulistas ajuda a multiplicar o uso da bioenergia. Seção Política C\&T. Revista Fapesp. $2012 ; 191$.

Lara LBLS, Artaxo P, Martinelli PB, Camargo RL, Victoria ESB, Ferraz ESB. Properties of aerosols from sugar-cane burning emissions in Southeastern Brazil. Atmos. Environ. 2005;26:4627-4637.

Lara LBLS, Artaxo P, Martinelli LA, Victoria RL, Camargo PB, Krusche A, Ayres GP, Ferraz ESB, Ballester MV. Chemical composition of rainwater and anthropogenic influences in the Piracicaba River Basin, Southeast Brazil. Atmospheric Environ. 2001;35(29):4937-4945.

Lim SS, Vos T, Flaxman AD, et al. A comparative risk assessment of Burden of disease and injury attributable to 67 risk factors and risk factor clusters in 21 regions, 1990-2010: a systematic analysis for the Global Burden of Disease Study 2010. Lancet 2012; 380:2224-2260.

Loch R, Nogueira E. Cartografia: representação, comunicação e visualização de dados espaciais. Florianopolis, SC: Ed. da UFSC, 2006. 
Logan WPD. Mortality in the London fog incident 1952. Lancet. 1953;1(6755):336-338.

Longo KM, Freitas SR1, Setzer A, Prins E, Artaxo P, Andreae M. The coupled aerosol and tracer transport model to the Brazilian developments on the Regional Atmospheric Modeling System (CATT-BRAMS). Part 2: Model sensitivity to the biomass burning inventories. Atmosph Chem Phys. 2010;10: 5785-5795.

Lopes FS, Ribeiro H. Mapeamento de internações hospitalares por problemas respiratórios e possíveis associações à exposição humana aos produtos da queima da palha de cana-de-açúcar no Estado de São Paulo. Rev. Bras Epidemiol. 2006;9(2):215-225.

Lopes LV, Derisso EM, Santarpio EAA Queima da palha da cana-deaçúcar e sua relação com problemas respiratórios. Revista Brasileira de Ciências da Saúde. 2007; ano III, nº 14.

Manço JC. Efeitos das Queimadas na saúde humana (aparelho respiratório). In: I Encontro sobre Incêndios Florestais, 1992, Botucatu. Resumo de Palestra. Botucatu: UNESP, FCA, SP-29 de julho de 1992.

Marcilio I, Gouveia NC. Quantificação do impacto da poluição atmosférica sobre a população urbana brasileira. Cad. Saúde Pública. 2007;23(Supl 4): 529-536.

Marinho CVA, Kirchoff VWH. Projeto fogo: um experimento para avaliar os efeitos das queimadas de cana-de-açúcar na baixa atmosfera. Rev. Bras Geofísica. 1991:9;107-119.

Martinelli LA, Filoso S. Expansion of sugarcane ethanol production in Brazil environmental and social challenges. Ecological Application. 2008 ;18(4):885-898.

Medronho RA [et al.] (Ed.). Epidemiologia I. 2.ed. São Paulo: Ed. Ateneu,2009.

Minas Gerais (Estado). Protocolo de eliminação da queima, 2008. Disponível em: http://www.agricultura.mg.gov.br/noticias/719.

Moraes MAFD. Indicadores do mercado de trabalho do sistema agroindustrial da cana-de-açúcar do Brasil no período 1992-2005. Estudos Econômicos. Instituto de Pesquisas Econômicas. 2007; 37:875902.

Murray CJL, Lopez AD. Measuring the Global Burden of Disease. N Engl J Med. 2013;369:448-57. 
Nastari P. Regra clara é essencial para mercados de açúcar e de etanol. Folha S. Paulo. 12 agosto 2011. Caderno Mercados. Commodities/Análise Cana, p. B11.

Neves MF, Chaddad FR. The Benefits of Sugarcane Chain Development in Africa Industry Speaks. International Food and Agribusiness Management Review. 2012;15(1):159-165.

Neves MF, Trombin VG, Consoli M. Mapping and Quantification of the sugar cane chain. FEARP Escola de Negócios - Universidade de São Paulo, Brazil Markestrat (Marketing \& Projetos Estratégicos e Centros de Pesquisa). Ribeirão Preto, SP, 2009.

Nigro F, Szwarc A. O etanol como combustível. In: Souza ELL, Macedo IC (coord.) Etanol e a bioeletricidade: a cana-de-açúcar no futuro da matriz energética. São Paulo: Luc Projetos de Comunicação, 2010. p. 154-189.

Ometto AR, Mangabeira JAC, Hott CM. Mapeamento de potenciais de impactos ambientais da queima de cana-de-açúcar no Brasil.12‥ Simpósio Brasileiro de Sensoriamento Remoto: Anais. Goiania, Brasil, 1621/04. 2005.

Pope III CA, Ezzati M. Fine-particulate air pollution and life expectancy in the United States. New Engl J Med. 2009;360 (4):376-386.

Pope III CA, Burnett RT, Thun MJ, Calle EE, Krewski D, Ito K, et al. Lung Cancer, Cardiopulmonary Mortality, and long-term exposure to fine particulate air pollution. JAMA. 2002; 287(9):1132-1141.

Pope III CA, Bates D, Raizenne ME. Health Effects of Particulate Air Pollution: Time for Reassessment? Environ Health Perspect. 1995;103:472-480.

Ramão FP, Schneider IE, Shikida PF. Padrão tecnológico no corte da cana-de-açúcar: um estudo de caso no Estado do Paraná. Rev. Econ. Agrícola. 2007;54: 21-32.

Rego JL. Fogo Morto. Romance. $75^{0}$ ed. Rio de Janeiro, José Olympio, 2013.

Ribeiro H. Queimadas de cana-de-açúcar no Brasil: efeitos à saúde respiratória. Rev. Saúde Pública. 2008; 42:370-376.

Ribeiro H, Assunção JV. Efeitos das queimadas na saúde humana. Rev. Estud. Avançados. 2002; 16(44):125-148.

Ribeiro H, Pesquero C. Queimadas de cana-de-açúcar: Avaliação de efeitos na qualidade do ar e na saúde respiratória de crianças. Estudos Avançados. 2010; 24 (68):255-271. 
Ripoli TCC, Ripoli MLC. Biomassa de cana-de-açúcar: colheita, energia e ambiente. Piracicaba, SP: Edição dos autores, 2009.

Rocha GO, Allen GA, Cardoso AA. Influence of agricultural biomass burning on aerosol size distribution and dry deposition in Southeastern Brazil. Environ Sci Technol. 2005;39(14):5293-5301.

Rose G. Sick people and sick population. Int. J. Epidemiol. 1985; 14:3238.

Roseiro MNV. Morbidade por problemas respiratórios em Ribeirão PretoSP de 1995 a 2001, segundo indicadores ambientais, sociais e econômicos. 2002. [Mestrado] Escola de Enfermagem de Ribeirão Preto da Universidade de São Paulo. Ribeirão Preto: USP

Roseiro MNV, Takayanagui AMM. Morbidade por problemas respiratórios em Ribeirão Preto (SP) de 1995 a 2001, segundo indicadores ambientais, sociais e econômicos. Rev. Paul Pediatria. 2006; 24(2):163-170.

Rothman KJ. Epidemiologia Moderna. 3.ed. Tradução de Geraldo Serra. Porto Alegre, RS: Artmed, 2011. Título original: Modern Epidemiology.

Rudorff BFT, Aguiar DA, Silva WF, Sugawara LM, Adami M, Moreira MA. Studies on the rapid expansion of sugarcane for ethanol production in São Paulo State (Brazil) using Landsat data. Remote Sens. 2010; 2:10571076.

Sanchez MO, Reis MA, Cruz ALS, Ferreira MP. Atuação do Cerest nas ações de vigilância em saúde do trabalhador no setor canavieiro. Saúde e soc. [online]. 2009;18(Suppl. 1):37-43..

Sá TDA, Kato OR, Carvalho CJR, Figueiredo RO. Queimar ou não queimar? De como produzir na Amazônia sem queimar. Rev. USP. 2007; 72:90-7.

São Paulo (Estado). Companhia Estadual de Tecnologia e Saneamento Ambiental- CETESB. A problemática da queima de palha dos canaviais. $1^{\circ}$ e 2․ Simpósios sobre a Queima de Palha dos Canaviais - 1984 e 1985. Anais. São Paulo: CETESB> Oliveira A. (coordenador), 1997.

São Paulo (Estado). Decreto no42. 056/97. Dispõe sobre o uso, conservação e preservação do solo agrícola. Disponível em: http://www.al.sp.gov.br/legislacao/norma.do?id=5298.

São Paulo (Estado). Companhia Estadual de Tecnologia e Saneamento Ambiental-CETESB Relatório de qualidade do ar no Estado de São Paulo 2008 [recurso eletrônico] / CETESB. - São Paulo: CETESB, 2009. 340 p. (Série Relatórios). 
São Paulo (Estado). Secretaria do Meio Ambiente. Projeto Etanol Verde 2007. Disponível em http://www.ambiente.sp.gov.br/etanolverde//.

São Paulo (Estado). Lei $n^{\circ} 11.241 / 02$. Dispõe sobre eliminação gradativa da queima da palha da cana-de-açúcar. Disponível em: $<$ http://www.al.sp.gov.br/legislacao>.

São Paulo (Estado). Resolução Conjunta da Secretaria do Meio Ambiente e Secretaria de Agricultura e Abastecimento - SMA-SAA no 6, de 24 de setembro de 2009. Dispõe sobre o Zoneamento Agroambiental para o setor sucroalcooleiro no Estado de São Paulo (Anexo 2). Disponível em: http://www.udop.com.br/download/legislacao/meio/zoneamento/res_sma_ conj_6.pdf

Scopinho RA, Eid F, Vian CE, Silva PR. Novas tecnologias e saúde do trabalhador: a mecanização do corte da cana-de-açúcar. Cad. Saúde Pública. 1999:15(1):147-162. [Serial on the Internet]. Jan [cited 2012 Aug 28]; 15(1):147-162.

Scopinho RA, Valarelli L. Modernização e impactos sociais: o caso da agroindústria sucroalcooleira da região de Ribeirão Preto (SP). Rio de Janeiro: Editora Fase, 1995.

Shy CM. The Failure of Academic Epidemiology: Witness for the Prosecution. Am. J. Epidemiol. 1997; 145(6):479-484.

Silva M. Mortes e acidentes nas profundezas do 'mar de cana' e dos laranjais paulistas. Rev. Gestão Integr. Saúde Trab. Meio Ambiente. 2008; 3:1-31.

Szmercsáni T. Tecnologia e degradação ambiental: 0 caso da agroindústria canavieira no Estado de São Paulo. Informações Econômicas IEA. 1994; 224:45-57.

Unica. União da Indústria de Cana-de-açúcar/ Ethanol Summit, 2011. Futuro: Fonte Inspiradora e Renovável. In: Futuro Verde: A cana-deaçúcar no centro da economia de baixo carbono. São Paulo: Unica/Ethanol Summit, 2011, p.20-33.

Unica. União da Indústria de Cana-de-açúcar. Protocolo Agroambiental do setor sucroalcooleiro paulista. São Paulo, 04 jun. 2007. Disponível em:<http://www.unica.com.br/userFiles/Protocolo_Assinado_Agroambient al.pdf>.

Uriarte M, Yackulic CB, Cooper T, Flynn D, Cortes M, Crk T, Cullman G, McGinty M, Sircely J. Expansion of sugarcane production in São Paulo, Brazil: implications for fire occurrence and respiratory health. Agro. Ecosyst. Environ. 2009; 132:48-56. 
WWF - World Wildlife Foundation do Brasil. Relatório do Programa Agricultura e Meio Ambiente: Análise da Expansão do Complexo Agroindustrial Canavieiro no Brasil; 2008.

Zafalon M. Cortadores de cana têm vida útil de escravo em São Paulo. Folha de São Paulo, 29 de abril de 2007. Caderno Dinheiro. p. B1.

llustração da capa da Tese. Regular Division of the Plane with Birds 1949 wood engraving. Disponível em: http://www.mcescher.com/ 
ANEXOS 


\section{ANEXOS}

\section{Anexo 1 - Lei 11.241. Dispõe sobre a eliminação gradativa da queima da palha de cana-de-açúcar e dá providencias correlatas ${ }^{40}$}

- Artigo $1^{0}$-Esta lei dispõe sobre a eliminação do fogo como método despalhador e facilitador do corte de cana-de-açúcar.

- Artigo $2^{0}$ - Os plantadores de cana-de-açúcar que utilizem como método de pré-colheita a queima da palha são obrigados às providencias necessárias para reduzir a prática, observadas as seguintes tabelas.

\begin{tabular}{l|l|l}
\hline \multicolumn{1}{c|}{ ANO } & $\begin{array}{c}\text { ÁREA MECANIZÁVEL ONDE NÃO SE } \\
\text { PODE EFETUAR A QUEIMA }\end{array}$ & $\begin{array}{c}\text { PERCENTAGEM DE } \\
\text { ELIMINAÇÃO DA QUEIMA }\end{array}$ \\
\hline $1^{\circ}$ ano(2002) & $20 \%$ da área cortada & $20 \%$ da queima eliminada \\
\hline $5^{\circ}$ ano(2006) & $30 \%$ da área cortada & $30 \%$ da queima eliminada \\
\hline $10^{\circ}$ ano(2011) & $50 \%$ da área cortada & $50 \%$ da queima eliminada \\
\hline $15^{\circ}$ ano(2016) & $80 \%$ da área cortada & $80 \%$ da queima eliminada \\
\hline $20^{\circ}$ ano $(2021)$ & $100 \%$ da área cortada & Eliminação total da queima \\
\hline
\end{tabular}

\begin{tabular}{|c|c|c|}
\hline ANO & $\begin{array}{c}\text { ÁREA NÃO MECANIZÁVEL, COM } \\
\text { DECLIVIDADE SUPERIOR A } 12 \% \text { E/OU } \\
\text { MENOR DE } 150 \text { ha (cento e cinqüenta } \\
\text { hectares), ONDE NÂO SE PODE } \\
\text { EFETUAR A QUEIMA }\end{array}$ & $\begin{array}{c}\text { PERCENTAGEM DE } \\
\text { ELIMINAÇÃO DA QUEIMA }\end{array}$ \\
\hline $10^{\circ}$ ano(2011) & $10 \%$ da área cortada & $10 \%$ da queima eliminada \\
\hline $15^{\circ}$ ano(2016) & $20 \%$ da área cortada & $20 \%$ da queima eliminada \\
\hline $20^{\circ}$ ano(2021) & $30 \%$ da área cortada & $30 \%$ da queima eliminada \\
\hline $25^{\circ}$ ano $(2026)$ & $50 \%$ da área cortada & $50 \%$ da queima eliminada \\
\hline $30^{\circ}$ ano(2031) & $100 \%$ da área cortada & $100 \%$ da queima eliminada \\
\hline
\end{tabular}

${ }^{40}$ Disponível em:

http://www.al.sp.gov.br/repositorio/legislacao/lei/2002/lei\%20n.11.241,\%20de\%2019.09.2 002.htm 


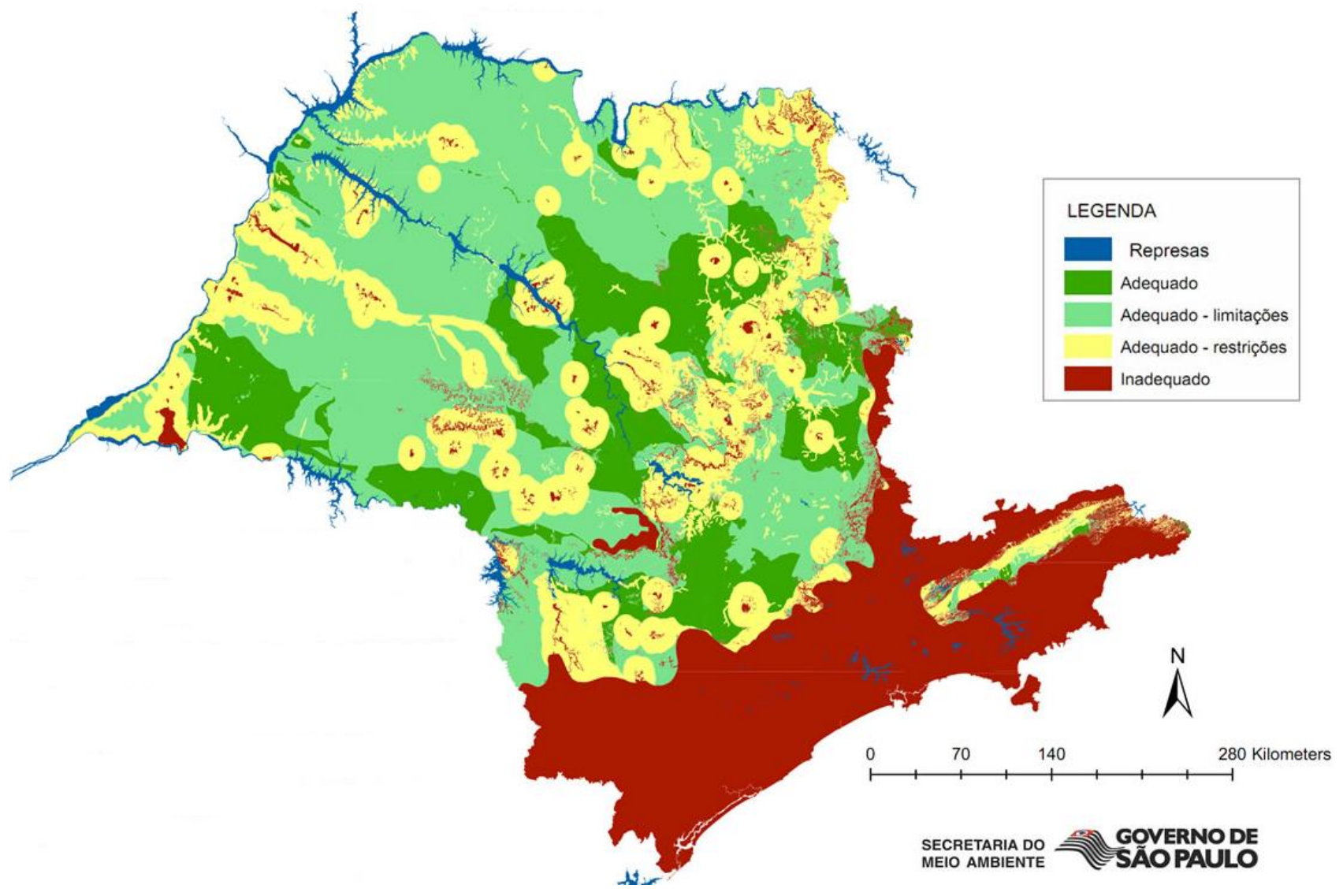

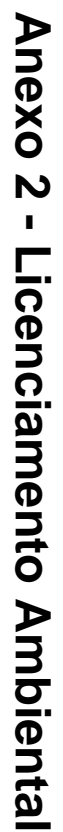

Fonte: FUNDAG - Governo do Estado de São Paulo

Figura 10 - Mapa de Zoneamento Agroambiental para o setor sucroalcooleiro do Estado de São Paulo 
O licenciamento das atividades é feito com base no mapa do Zoneamento Agroambiental do Estado de São Paulo (Figura 10), segundo quatro classes, com diferentes graus de aptidão agroambiental.

Os parâmetros específicos de acordo com cada área para a obtenção de licenças e operação dos empreendimentos são:

I - Viabilidade ambiental por meio de estudo apropriado nos termos definidos pela Resolução SMA nำ42-2006;

II - Adoção de manejo adequado de defensivos agrícolas, nas áreas de influência dos pontos de captação de águas para abastecimento público; III - Apresentação, por ocasião da solicitação da Licença de Operação (LO), da lista de fornecedores de cana-de-açúcar;

IV - Adoção de ações de fomento, tais como a conscientização, o incentivo e a prestação de assistência técnica, objetivando a não utilização, a proteção e a recuperação de Áreas de Preservação Permanente (APPs), remanescentes de vegetação nativa primária dos biomas Mata Atlântica e Cerrada, bem como das formações secundárias no estágio avançado de regeneração e das várzeas naturais não cultivadas, em áreas de terceiros, arrendadas e de fornecedores;

V - Ações de recuperação com espécies nativas nas Áreas de Preservação Permanente (APPs); nas áreas próprias, como medida mitigadora dos impactos ambientais da atividade, sendo que, no caso de licenciamento de ampliações, aplica-se somente para as novas áreas de plantio de cana-de-açúcar;

VI - Utilização de limite máximo de um $\mathrm{m}^{3}$ (um metro cúbico) de água por tonelada de cana-de-açúcar moída para os novos empreendimentos; e 
VII - Apresentação de Plano de Minimização de consumo de água, com cronograma de adequação para atingir limite máximo de $1 \mathrm{~m}^{3}$ (um metro cúbico) por tonelada de cana-de-açúcar moída para ampliações de empreendimentos existentes.

Nas áreas classificadas como Adequadas e com Limitações Ambientais, o licenciamento ambiental de novos empreendimentos e de ampliações de empreendimentos existentes do setor sucroalcooleiro ficará condicionado às exigências citadas, acrescidas de:

I - Demonstração de adoção de equipamentos de controle, de procedimentos operacionais e de monitoramento que garantam 0 atendimento aos limites de emissões para os poluentes: Material Particulado e Óxidos de Nitrogênio, nas chaminés das caldeiras a bagaço; II - Demonstração da preservação integral dos remanescentes de vegetação nativa primária dos Biomas Mata Atlântica e Cerrado, bem como das formações secundárias no estágio avançado de regeneração e das várzeas naturais não cultivadas, na área onde estiver instalada a unidade industrial e nas áreas próprias de cana-de-açúcar do empreendimento; e

III - Exclusivamente nos casos de instalação de novos empreendimentos ou expansão dos existentes localizados em Áreas de Proteção Ambiental (APAs), apresentar estudo específico de avaliação de eventuais impactos adversos sobre os atributos dessas áreas e as medidas mitigadoras desses impactos.

Nas áreas classificadas como Adequadas com Restrições Ambientais, o licenciamento ambiental de novos empreendimentos e de 
ampliações de empreendimentos existentes do setor sucroalcooleiro ficará acrescidas de:

I - Demonstração de viabilidade ambiental por meio da elaboração de Estudo de Impacto Ambiental e respectivo Relatório de Impacto Ambiental (EIA - Rima), independentemente de seu porte;

II - Adoção da melhor tecnologia prática disponível visando à minimização da geração de vinhaça;

III - Utilização de limite máximo de $0,7 \mathrm{~m}^{3}$ de água por tonelada de canade-açúcar moída para novos empreendimentos; e

IV - Apresentação de Plano de Minimização de consumo de água, com cronograma de adequação para atingir o consumo de 0,7 m3por tonelada de cana-de-açúcar moída para ampliações de empreendimentos existentes.

Nas áreas classificadas como Adequadas com Restrições Ambientais, conforme os mapas "Prioridade para incremento da Biodiversidade (conectividade BIOTA)" e "Unidades de Conservação de Proteção Integral (existentes e indicadas- BIOTA)"41, o licenciamento ambiental de novos empreendimentos e de ampliações de empreendimentos existentes do setor sucroalcooleiro ficará condicionado à:

I - Formação de corredores ecológicos dentro do perímetro de influência direta do empreendimento, por meio da preservação e da recuperação de formações florestais, nativas ou recompostas, árvores isoladas e várzeas,

\footnotetext{
${ }^{41}$ Disponível em: www.ambiente.sp.gov.br-etanolverde.
} 
unindo-as com Áreas de Preservação Permanente (APPs), conforme definido no EIA e respectivo RIMA;

II - Adoção de planejamento da colheita de modo a minimizar influências negativas sobre a fauna silvestre, especialmente o atropelamento de animais;

III - Elaboração e implantação de plano de monitoramento da fauna silvestre, contemplando a área de influência direta do empreendimento, conforme definido no EIA e no respectivo RIMA; e

IV - Apresentação de planos para minimizar eventuais impactos ambientais da atividade em licenciamento sobre a biota legalmente protegida e de interferência nos fluxos gênicos entre populações de plantas e animais presentes em remanescentes de vegetação nativa, áreas de preservação permanente e Unidades de Conservação.

Nas áreas Adequadas com Restrições Ambientais e nas áreas de alta vulnerabilidade, conforme o Mapa "Disponibilidade de Águas Superficiais e Vulnerabilidade das Águas Subterrâneas" a aplicação de vinhaça fica condicionada à apresentação de relatório contendo a caracterização hidrogeológica, com o objetivo de determinar a vulnerabilidade do aquífero local.

Nas áreas classificadas como Inadequadas, não serão aceitos pedidos de licenciamento ambiental, protocolados após a publicação da Resolução SMA nº 67, de 18 de setembro de 2008.

No caso de renovação de Licença de Operação (LO) dos empreendimentos já licenciados, o empreendedor deverá apresentar um 
Plano de Adequação às condicionantes estabelecidas nesta Resolução, para a área correspondente, dentro dos seguintes prazos:

I - para as usinas que estejam em conformidade com o Protocolo Agroambiental, poderá ser de até 15 (quinze) anos;

II - para as demais usinas, deverá obedecer às regras de renovação vigentes. As usinas que tiverem cumprido integralmente as condicionantes e as recomendações da Licença de Operação (LO) e das renovações, e que estiverem em conformidade com o Protocolo Agroambiental poderão ter o prazo de renovação ampliado de um a três anos em relação ao prazo máximo estabelecido no Decreto Estadual no 8. 468/1976 e suas alterações.

Em caso de empreendimentos em análise, quando for necessário alterar o Relatório Ambiental Preliminar (RAP) apresentado para Estudo de Impacto Ambiental e Relatório de Impacto Ambiental (EIA-RIMA), o RAP será considerado como o Plano de Trabalho e o Departamento de Avaliação de Impacto Ambiental - DAIA emitirá o Termo de Referência para a elaboração do EIA-RIMA.

Os roteiros para estudos ambientais que atendam ao disposto na presente resolução serão disponibilizados no endereço eletrônico www.ambiente.sp.gov.br. 


\section{Anexo 3 - Projeto CANASAT/INPE ${ }^{42}$}

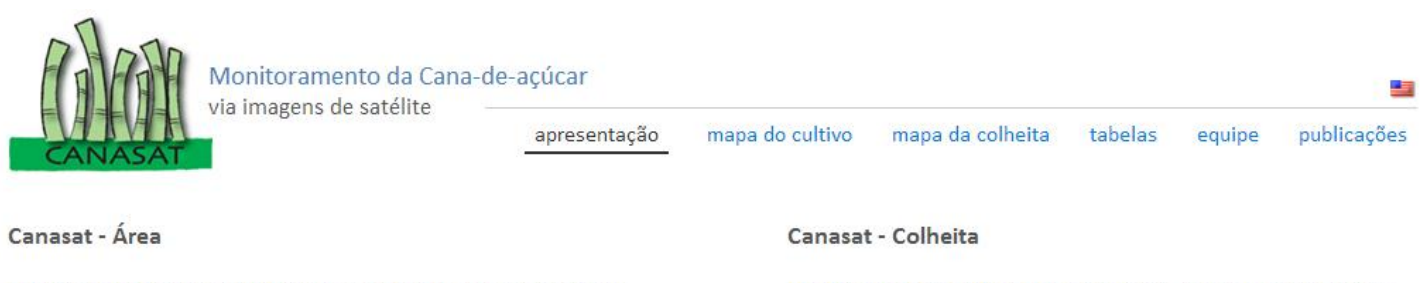

Monitoramento anual do cultivo da cana-de-açúcar nas seguintes classes: soca, expansão, em reforma (18 meses) e reformada (18

Monitoramento anual do tipo de colheita, com ou sem a queima meses).

Mapas, gráficos e tabelas da área cultivada com cana-de-açúcar

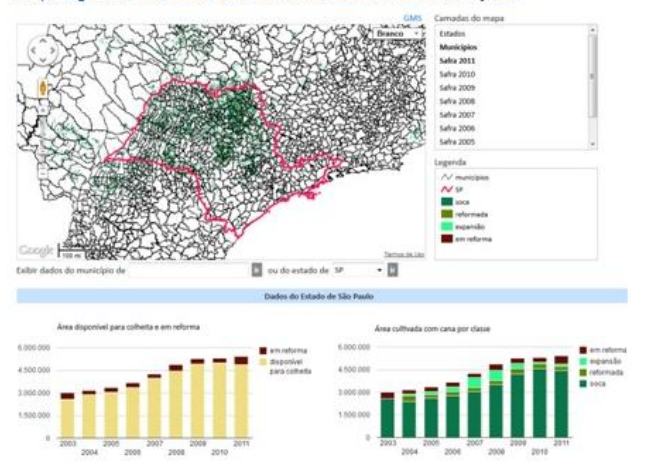
da palha da cana-de-açúcar.

Mapas e gráficos do tipo de collheita da cana-de-açúcar

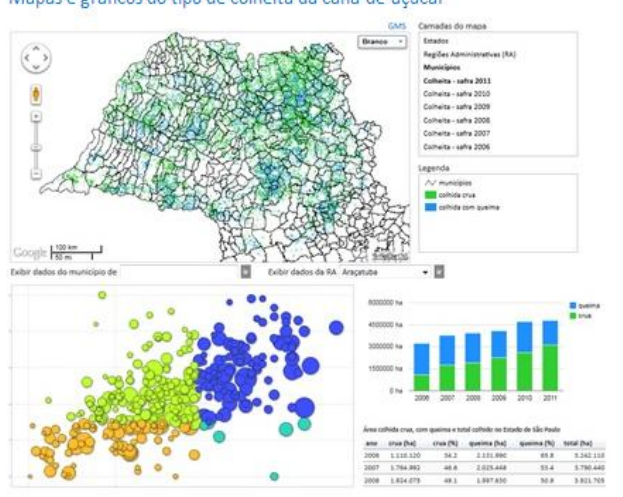

${ }^{42}$ Disponível em: http://www.dsr.inpe.br/laf/canasat/. 


\section{Anexo 4 - Sistema de Informações Ambientais Integrado à Saúde Ambiental (SISAM) ${ }^{43}$}

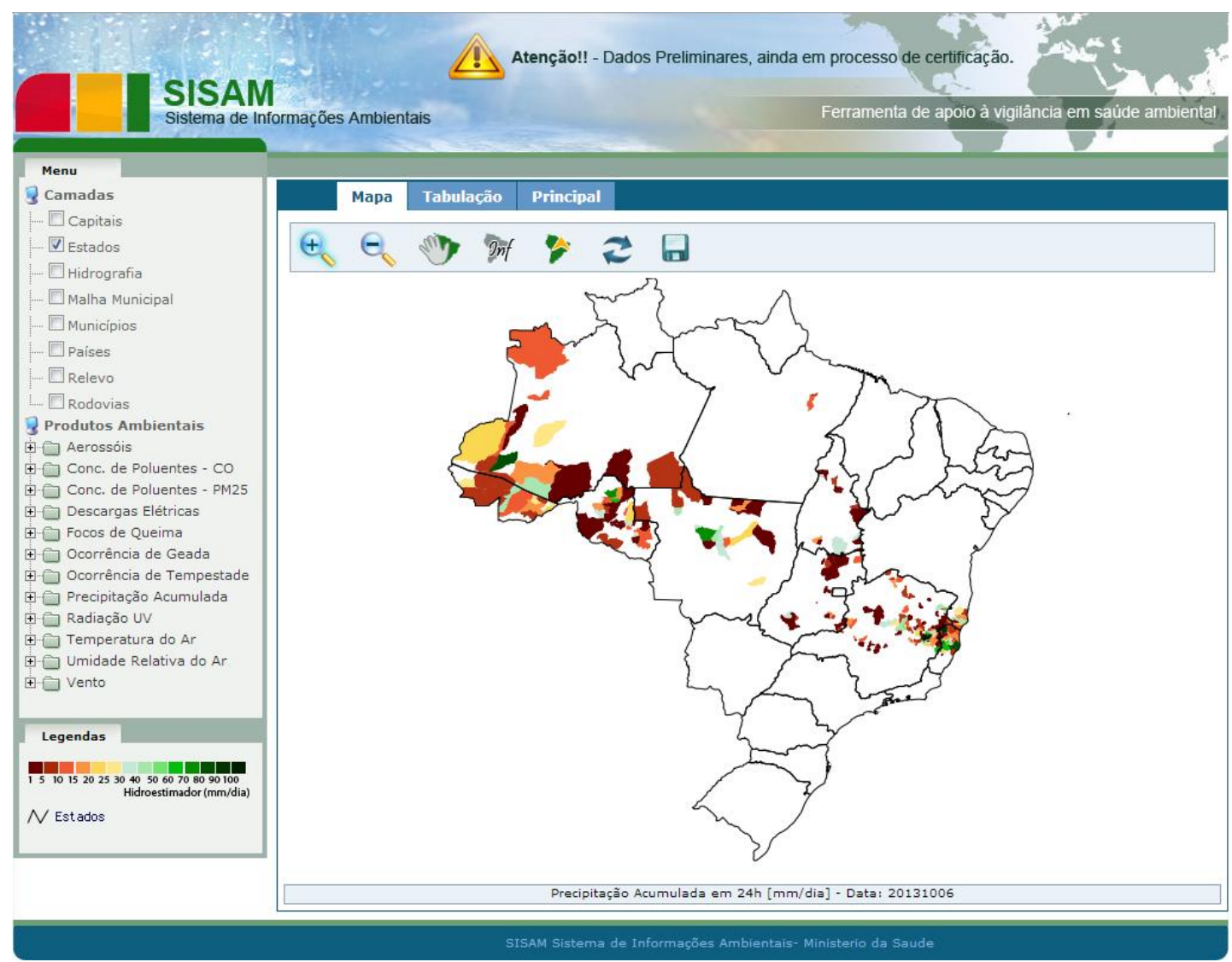

\footnotetext{
${ }^{43}$ Disponível em: http://sisam.cptec.inpe.br/sisam.
} 
Anexo 5 - Focos de queima no Estado de São Paulo. Período 2006-2010

Estudo da distribuição mensal do número Focos de Queima, 482 municípios paulistas com cana-de-açúcar em 2010, no período de 2006 a 2010.

\begin{tabular}{|c|c|c|c|c|c|c|}
\hline ANO & 2006 & 2007 & 2008 & 2009 & 2010 & TOTAL \\
\hline MÊS & & & & & & MÊS \\
\hline \multirow{3}{*}{$\begin{array}{l}\text { Janeiro } \\
\text { Fevereiro } \\
\text { Março }\end{array}$} & 256 & 55 & 77 & 233 & 104 & 725 \\
\hline & 236 & 185 & 67 & 123 & 443 & 1054 \\
\hline & 385 & 494 & 147 & 201 & 518 & 1745 \\
\hline \multirow{5}{*}{$\begin{array}{l}\text { Abril } \\
\text { Maio } \\
\text { Junho } \\
\text { Julho } \\
\text { Agosto }\end{array}$} & 1167 & 669 & 270 & 1230 & 879 & 4215 \\
\hline & 2335 & 994 & 733 & 1480 & 1108 & 6650 \\
\hline & 3232 & 1315 & 500 & 942 & 1853 & 7842 \\
\hline & 3893 & 993 & 1801 & 986 & 3393 & 11066 \\
\hline & 5785 & 2786 & 1947 & 1822 & 5785 & 18125 \\
\hline \multirow{2}{*}{$\begin{array}{l}\text { Setembro } \\
\text { Outubro }\end{array}$} & 5236 & 3564 & 2775 & 993 & 6074 & 18642 \\
\hline & 2020 & 2130 & 1128 & 972 & 2255 & 8505 \\
\hline \multirow{3}{*}{$\begin{array}{l}\text { Novembro } \\
\text { Dezembro }\end{array}$} & 1357 & 783 & 1576 & 796 & 1449 & 5961 \\
\hline & 145 & 467 & 1430 & 273 & 317 & 2632 \\
\hline & 26047 & 14435 & 12451 & 10051 & 24178 & \\
\hline
\end{tabular}

Fonte: INPE, todos os satélites. 


\section{Anexo 6 - Resolução CONAMA nº 03/90}

\section{$[\ldots]$}

Art. 3o Ficam estabelecidos os seguintes Padrões de Qualidade do Ar:

I - Partículas Totais em Suspensão

a) Padrão Primário

1 - concentração média geométrica anual de 80 (oitenta) microgramas por metro cúbico de ar.

2 - concentração média de 24 (vinte e quatro) horas de 240 (duzentos e quarenta) microgramas por metro cúbico de ar, que não deve ser excedida mais de uma vez por ano.

b) Padrão Secundário

1 - concentração média geométrica anual de 60 (sessenta) micro gramas por metro cúbico de ar.

2 - concentração média de 24 (vinte e quatro) horas, de 150 (cento e cinqüenta) micro-gramas por metro cúbico de ar, que não deve ser excedida mais de uma vez por ano.

II - Fumaça

a) Padrão Primário

1 - concentração média aritmética anual de 60 (sessenta) microgramas por metro cúbico de ar.

2 - concentração média de 24 (vinte e quatro) horas, de 150 (cento e cinqüenta) microgramas por metro cúbico de ar, que não deve ser excedida mais de uma vez por ano.

b) Padrão Secundário

1 - concentração média aritmética anual de 40 (quarenta) microgramas por metro cúbico de ar.

2 - concentração média de 24 (vinte e quatro) horas, de 100 (cem)

microgramas por metro cúbico de ar, que não deve ser excedida uma de urna vez por ano.

III - Partículas Inaláveis

a) Padrão Primário e Secundário

1 - concentração média aritmética anual de 50 (cinquenta) microgramas por metro cúbico de ar. 
2 - concentração média de 24 (vinte e quatro) horas de 150 (cento e cinqüenta) microgramas por metro cúbico de ar, que não deve ser excedida mais de uma vez por ano.

IV - Dióxido de Enxofre

a) Padrão Primário

1- concentração média aritmética anual de 80 (oitenta) microgramas por metro cúbico de ar.

2- concentração média de 24 (vinte e quatro) horas, de 365 (trezentos e sessenta e cinco) microgramas por metro cúbico de ar, que não deve ser excedida mais de uma vez por ano.

b) Padrão Secundário

1 - concentração média aritmética anual de 40 (quarenta) microgramas por metro cúbico de ar.

2 - concentração média de 24 (vinte e quatro) horas, de 100 (cem)

microgramas por metro cúbico de ar, que não deve ser excedida mais de uma vez por ano.

V - Monóxido de Carbono

a) Padrão Primário e Secundário

1 - concentração médio de 8 (oito) horas, de 10.000 (dez mil) microgramas por metro cúbico de ar (9 ppm), que não deve ser excedida mais de uma vez por ano.

2 - concentração média de 1 (uma) hora, de 40.000 (quarenta mil) microgramas por metro cúbico de ar (35 ppm), que não deve ser excedida mais de uma vez por ano.

VI - Ozônio

a) Padrão Primário e Secundário

1 - concentração média de 1 (uma) hora, de 160 (cento e sessenta) microgramas por metro cúbico do ar, que não deve ser excedida mais de uma vez por ano.

VII - Dióxido de Nitrogênio

a) Padrão Primário

1 - concentração média aritmética anual de 100 (cem) microgramas por metro cúbico de ar.

2 - concentração média de 1 (uma) hora de 320 (trezentos e vinte) microgramas por metro cúbico de ar.

b) Padrão Secundário

1 - concentração média aritmética anual de 100 (cem) microgramas por metro cúbico de ar.

2 - concentração média de 1 (uma) hora de 190 (cento e noventa)

microgramas por metro cúbico de ar. 